University of San Diego

Digital USD

Theses

Theses and Dissertations

Winter 1-31-2021

\title{
Coastal watershed monitoring and management: Geomorphology, geochemistry, and hydrologic modeling of Los Peñasquitos Creek, CA
}

Ravleen Khalsa-Basra

University of San Diego

Follow this and additional works at: https://digital.sandiego.edu/theses

Part of the Analytical Chemistry Commons, Climate Commons, Environmental Chemistry Commons, Geochemistry Commons, Geomorphology Commons, Hydrology Commons, Inorganic Chemistry Commons, Other Environmental Sciences Commons, Sedimentology Commons, and the Water Resource Management Commons

\section{Digital USD Citation}

Khalsa-Basra, Ravleen, "Coastal watershed monitoring and management: Geomorphology, geochemistry, and hydrologic modeling of Los Peñasquitos Creek, CA" (2021). Theses. 49.

https://digital.sandiego.edu/theses/49

This Thesis: Open Access is brought to you for free and open access by the Theses and Dissertations at Digital USD. It has been accepted for inclusion in Theses by an authorized administrator of Digital USD. For more information, please contact digital@sandiego.edu. 


\title{
UNIVERSITY OF SAN DIEGO
}

\author{
San Diego
}

\section{Coastal watershed monitoring and management:}

Geomorphology, geochemistry, and hydrologic modeling of Los Peñasquitos Creek, CA

A thesis submitted in partial satisfaction of the requirements for the degree of

Master of Science in Environmental and Ocean Sciences

by

Ravleen Kaur G. Khalsa-Basra

Thesis Committee

Suzanné C. Walther, Ph.D., Chair

Zhi Yong-Yin, Ph.D.

Eric M. Cathcart, P.G. 
Copyright 2021

Ravleen Kaur G. Khalsa-Basra 


\section{ACKNOWLEDGEMENTS}

Before beginning this journey, the thought of physically leaving behind stability and long-term plans on a mere drive to dive into something new and far was not an easy decision and it came with many fears. Regardless, I took a logical leap of faith for what I thought could be my passion. Throughout the journey, I encountered several thorns but stopped to smell so many more roses. I've learned, I've grown and, often, I've persevered. But most importantly, I am eager for more. The credit is not mine alone but to the program and the following people who supported, taught, and inspired me.

To the person who inspires me the most, I must thank my thesis chair Dr. Suzanné Walther. I came with very little experience in this discipline and I could not be more appreciative for her giving me a chance and really nurturing the skills I wanted to develop through this process. I am so fortunate to have had a teacher and advisor who positively impacted my whole experience through her excitement about geomorphology, her dedication to her work and students, and her compassion for all people. She challenged me, comforted me, and celebrated all the little wins with me, and I am forever grateful for her mentorship and friendship.

I would also like to give many thanks to my committee members, Dr. John Yin and Eric Cathcart for their guidance on my thesis. John was my first professor in the program and I was glowing with excitement after every class because of his deep understanding of physical geography and climate. He pushed me to ask "why" and really understand each topic, to the point I would read on to other 
chapters and spend hours online trying to learn more. He also committed a great deal of time and thought for my third chapter and I am thankful for all his insight to improve my research. Eric has been an integral part of my work. He was always encouraging and available with open doors and phone calls. He helped with the initial proposal and permitting process, assisted me with field work, taught me how to use all the instruments for my lab work, and shared his vast regional knowledge along with helpful resources. I am immensely thankful for all you have done.

The entire Environmental and Ocean Sciences department deserves a special thanks. This includes the generosity of allowing me to use their scientific instruments and materials (Dr. Beth O'Shea, Dr. Nathalie Reyns, Dr. Sarah Gray), training and wonderful conversations (Keith Fink, Russell Harrel, Liz BakerTreloar, Dr. Michel Boudrias), and providing additional assistance on my thesis and grad school experience (Dr. Jennifer Prairie, Dr. Drew Talley, Dr. Ron Kaufmann, Soroya Rowley). In addition, I want Dr. Steven Searcy to know how much he contributed to my experience here - from opening my eyes and heart to the world of ecology \& field work to consistently checking up on me and my research. I would also like to thank everyone who helped me with my own field work, suited up, got poison oak, and mosquito bites, and did it all with a smile. Thank you to my cohort and friends for all your support and friendship through this time, you have become my family away from home.

A big thanks to my parents and family back east for being supportive of my endeavors, for accepting my leaving the nest and pursuing a completely 
different career path than we all thought. I also appreciate the continued encouragement. The greatest thank you goes to Ekjot, my husband and best friend for supporting me (emotionally, financially, and technologically) and always being the biggest advocate for chasing my dreams. I could not have done this without him.

Lastly, thank you to a past me who made a spontaneous decision to take this road and embraced all the challenges. I am still so motivated to learn and grow in this field which confirms that the decision I made a few years ago and occasionally second guessed, was the right one for me. I am grateful for who I have become now and for each of the strong-willed individuals in this acknowledgment who helped me get there - how blessed am I to have had such an experience with incredible people, making this chapter of life so hard to close. 


\section{TABLE OF Contents}

List of figures

List of tables

Chapter 1: INTRODUCTION

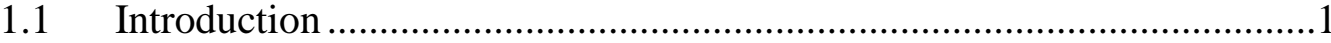

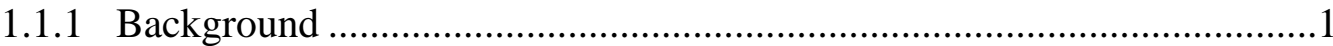

1.2 Literature Review ........................................................................ 3

1.2.1 Spatial characteristics in fluvial geomorphology ..................................

1.2.2 Chemical stressors in the environment.................................................

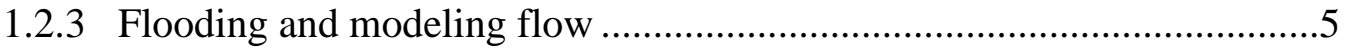

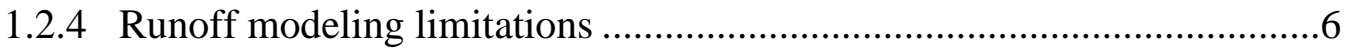

1.2.5 IPCC regional climate projections ..............................................

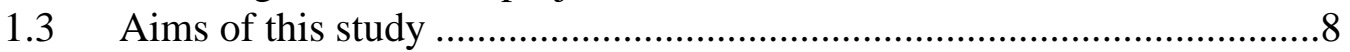

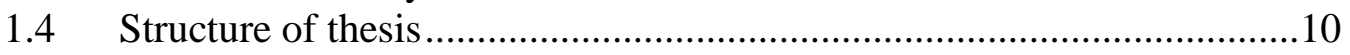

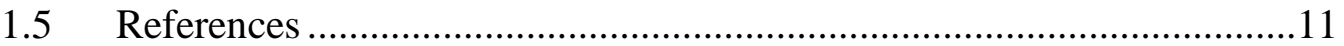

Chapter 2: QUANTIFYING LONGITUDINAL VARIATION IN FLUVIAL MORPHOLOGY, METALS, AND NUTRIENTS OF LOS PEÑASQUITOS CREEK, SAN DIEGO COUNTY, CA

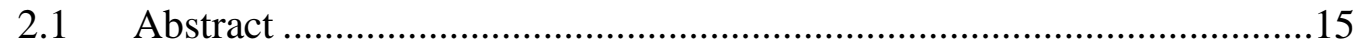

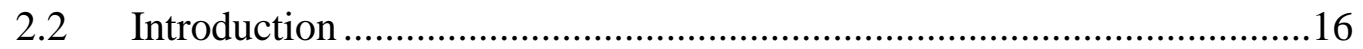

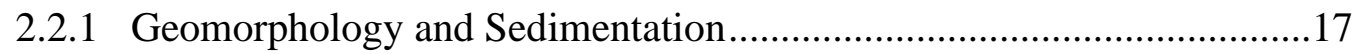

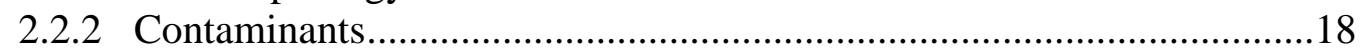

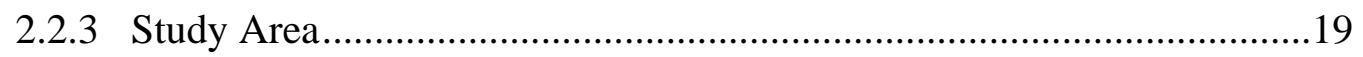

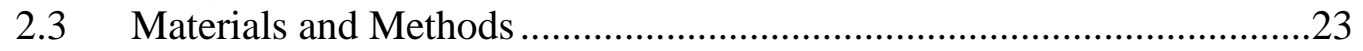

2.3.1 Field Methods: Site selection, surveying, and sampling ......................23

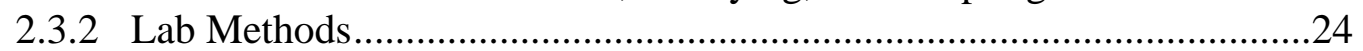

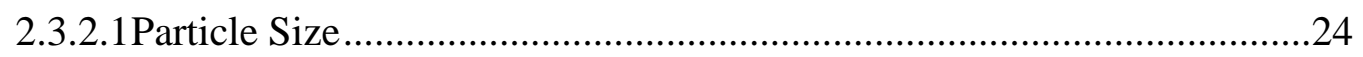

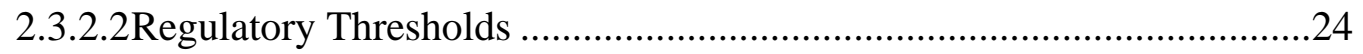

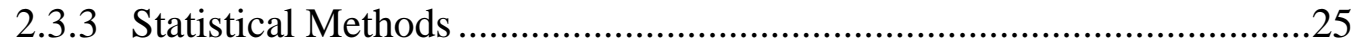

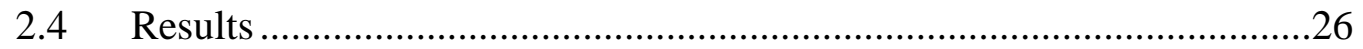

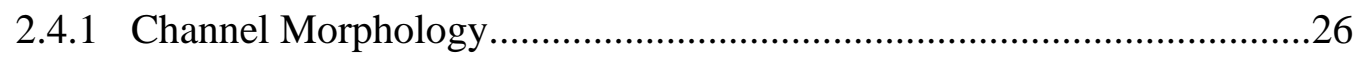

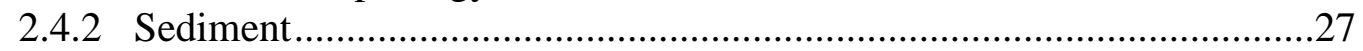

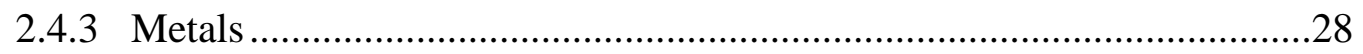

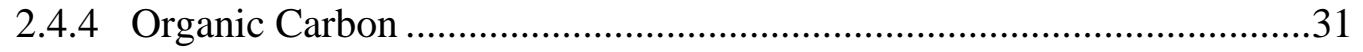

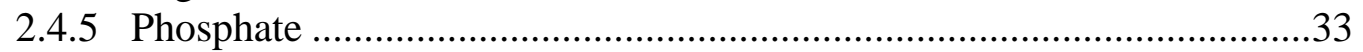

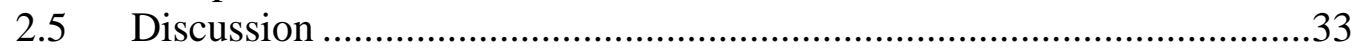

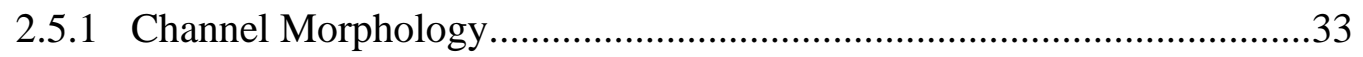

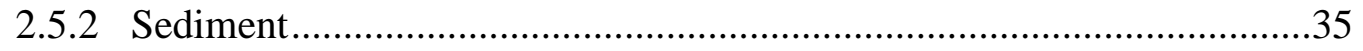

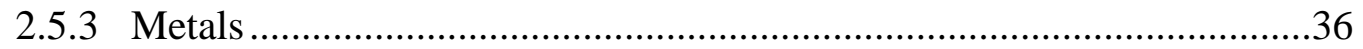

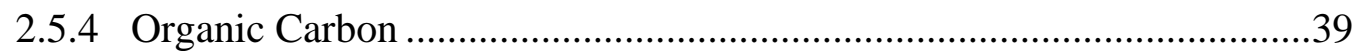

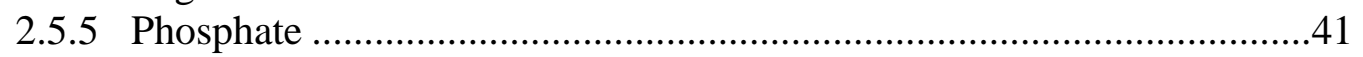

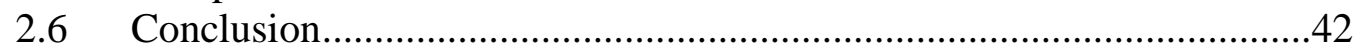

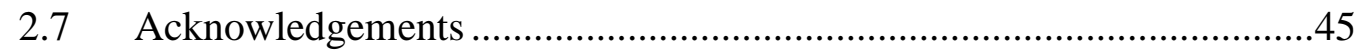

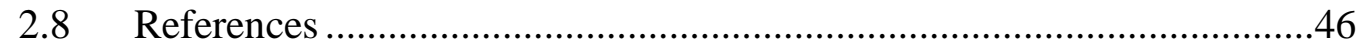


Chapter 3: MAPPING FLOOD AT LOS PEÑASQUITOS CREEK, A SMALL, URBANIZED, COASTAL WATERSHED IN SOUTHERN CALIFORNIA

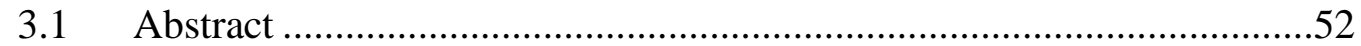

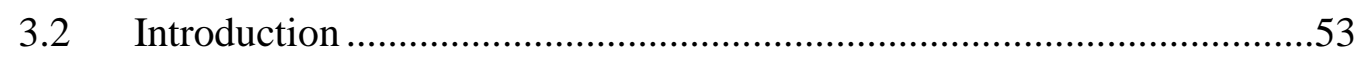

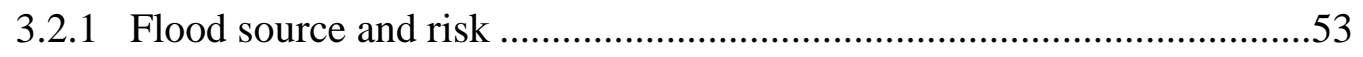

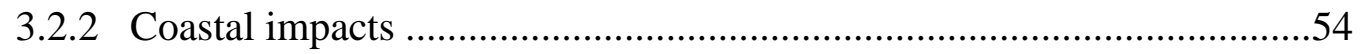

3.2.3 Anthropogenic impacts................................................................55

3.2.4 Representative Concentration Pathways and Flow Modeling .................55

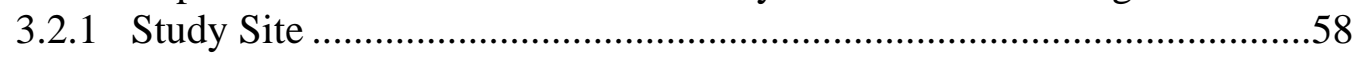

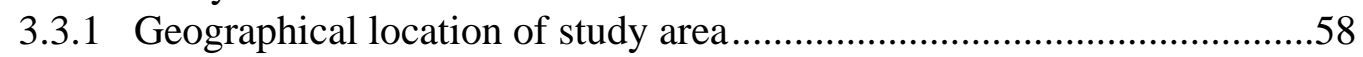

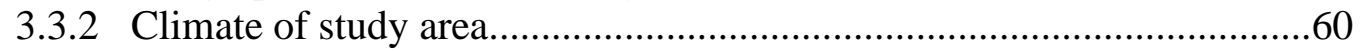

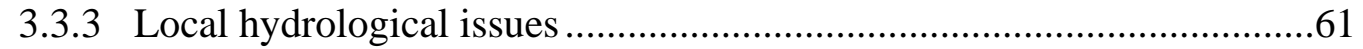

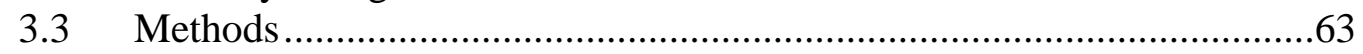

3.4.1 Calculating RI Flows.................................................................63

3.4.2 Estimating runoff from precipitation and CMIP5 ...............................64

3.4.3 Antecedent Precipitation Index (API) ...........................................6. 65

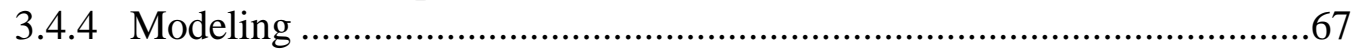

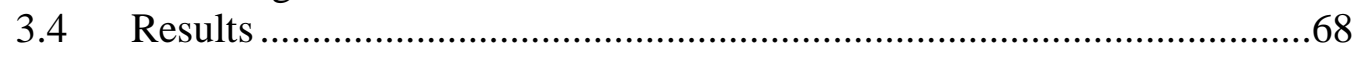

3.4.1 Recurrence Interval Flow Projections ..............................................68

3.4.2 RCP Modeled Flow Projections ..................................................... 70

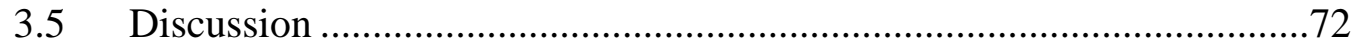

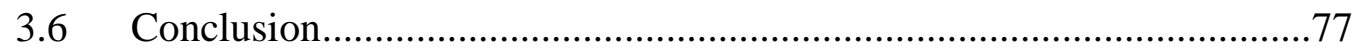

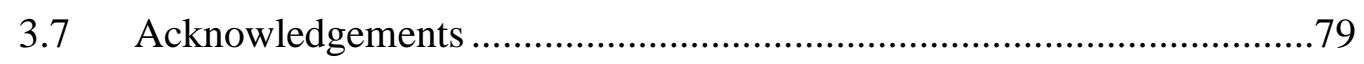

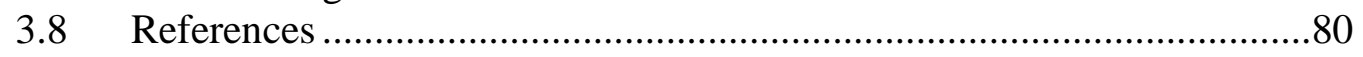

Chapter 4: SUMMARY AND CONCLUSIONS

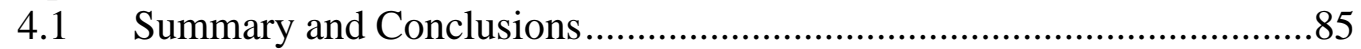

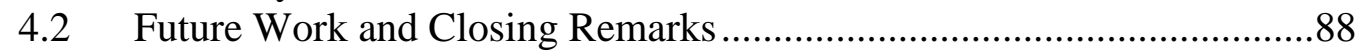

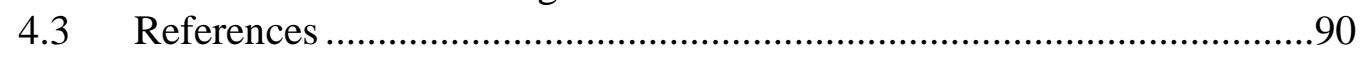

$\begin{array}{lr}\text { Appendix A: Site descriptions } & 92\end{array}$

Appendix B: Cross sectional discharge $\quad 100$

Appendix C: Grain size distribution data $\quad 111$

$\begin{array}{ll}\text { Appendix D: Bulk metals data } & 114\end{array}$

Appendix E: Correlation Analysis 126

Appendix F: Runoff multiple regression with API and Precipitation 127 


\section{LIST OF FIGURES}

Figure 2.1 Local climate monthly averages .................................................20

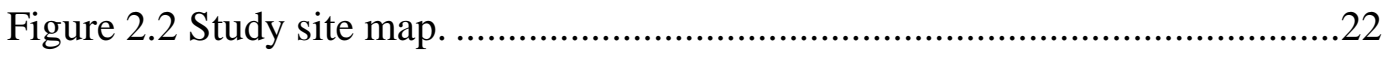

Figure 2.3 Downstream geomorphic variables .............................................2

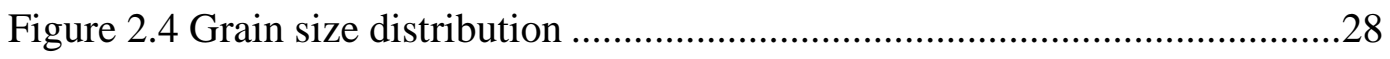

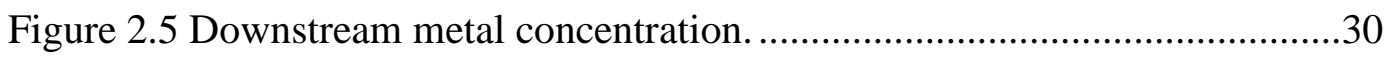

Figure 2.6 Average channel vs bank downstream metal. .....................................31

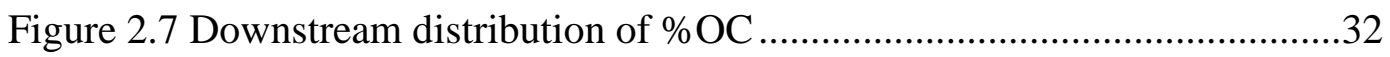

Figure 2.8 Downstream phosphate and water quality.......................................33

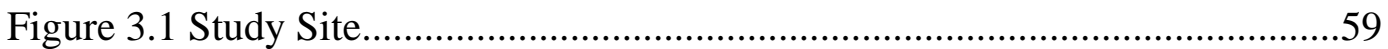

Figure 3.2 Local monthly climatic variables averages (1989-2019). ..................60

Figure 3.3 PeakFQ probabilities and RI flows.................................................68

Figure 3.4 Modeled flows for RI-5, 50, 500 and flood inundation widths ............70

Figure 3.5 Observed vs Projected annual precipitation $(\mathrm{P})$ extremes....................71

\section{LIST OF TABLES}

Table 2.1 Geomorphic variables calculated and measured.................................26

Table 2.2 CGS Cumulative particle size and sorting ......................................27

Table 2.3 Effects Range Low and Metal concentrations (ppm). ..........................29

Table 2.4 Statistics (95\% UCL for Metals, OLS regression \%OC \& \%Fine) ........32

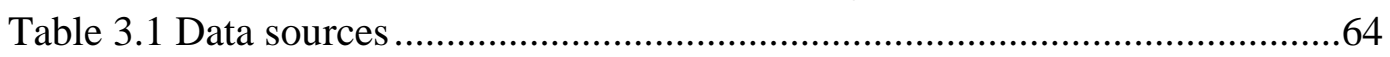

Table 3.2 Calculated Recurrence Intervals and estimated channel width ............69

Table 3.3 RCP precipitation estimates to calculate future flows ..........................72 


\section{CHAPTER 1: INTRODUCTION}

\subsection{Introduction}

\subsubsection{Background}

Worldwide, Southern California is acclaimed for its desirable climate, social and economic opportunity, and natural geography (proximity to the ocean, mountains, and desert). This combination of ideal characteristics has led the region to population growth, particularly in San Diego (Messner, Miranda, \& Young, 2011). The land-use change from new development in Southern California's limited open spaces have contributed significantly to local hydrology and therefore, the ecosystem (Mazor, Mccune, May, Bledsoe, \& Stein, 2018; Taniguchi \& Biggs, 2015; White \& Greer, 2006). Southern California watersheds are unique in their geography, climate, and drainage. They must be studied apart from traditional watersheds due to the value of their unique geographical features: small spatial scale providing limited open-spaces, high land demand, direct coastal impact, and limited flowing fresh water. To properly maintain watershed functions despite climate change and population rise, it is important to first establish watershed-specific baseline data for fluvial geomorphology, water and soil quality, and surface-water hydrology. Even more so for modeling and projecting into the future for planning and management.

Located in west-central San Diego, CA, Los Peñasquitos Watershed (LPW) is an example of a small, urbanized watershed with direct impact on Los Peñasquitos Lagoon (LPL), a pacific coast estuary. The three rivers that flow into LPL are Los Peñasquitos Creek (LPC), Carmel Creek (north), and Carroll Canyon Creek (south). The watershed is 60,149 acres, with the largest total maximum 
daily load (TMDL) coming from Carroll Canyon Creek (south) because of the impervious land ratio in this sub-watershed from primarily industrial land use (Weston Solutions Inc., 2009). In fact, a management priority in 2009 was to reduce sedimentation and siltation, as per a TMDL within the Peñasquitos watershed (Weston Solutions Inc., 2009).

Although Los Peñasquitos Creek sub-watershed has a wider floodplain and a higher undeveloped:developed ratio than Carroll Creek, LPC sub-watershed continues to grow in development. Furthermore, the greatest acreage, residential space, and surface water impoundment within the greater watershed, is in LPC sub-watershed. The once intermittent channels all became perennial around 1995 due to development in the fast-growing cities of Poway, Del Mar, and San Diego (California Department of Transportation, 2009; Weston Solutions Inc., 2009). A 2006 study by White and Greer found that urbanization increased in LPC watershed from 9-37\% from 1966-1999 (undeveloped land decreased by 30\%). During this period, there was no change in rainfall, but runoff increased by $4 \%$ each year (overall 200\% runoff increase from 1973-2000). The need to reduce sediment load continued to be part of the 2015 improvement plan (California Department of Transportation, 2015). This plan led to a study in 2016 which determined the priority locations for outfall relocation or repair to reduce $50 \%$ $84 \%$ of the annual 6,000 tons of sediment loading via erosion (Tetra Tech Inc., 2016). In a subsequent study, Bennett (2018) found that urbanization increased another $8 \%$ from 2000-2017 in the upper hydrologic unit of the Peñasquitos subwatershed. With continued decrease of permeable land cover in LPC sub- 
watershed and increasing flow, it is imperative to establish a baseline for the hydrologic variables and continue monitoring in highly sensitive areas, especially because quality at LPC could potentially worsen to the levels of Carroll Canyon. Moreover, the potential for sediment and water to transport bioavailable pollutants, such as metals and nutrients, may cause ecologic distress in the lagoon.

\subsection{Literature Review}

\subsubsection{Spatial characteristics in fluvial geomorphology}

Relationships between river variables, including width, depth, velocity, sediment load, and discharge measured at cross sections within the channel (Leopold \& Maddock, 1953), can be used to understand fluvial dynamics and sedimentary processes. Factors such as slope, channel shape, water resources, and roughness influence deposition and discharge (Bierman \& Montgomery, 2020; Phillips \& Slattery, 2007). In traditional river systems, headwaters are narrow with high velocity, low flow, steep slope, and larger unconsolidated gravels. As slope shallows downstream, channels widen, deepen, increase in flow, and become finer grained (Bierman \& Montgomery, 2020). While these are established trends in river morphology, local geography, climate, and point-source inputs can alter these patterns (Hawley \& Bledsoe, 2011; Phillips \& Slattery, 2007). Even in semi-arid climates, there are micro-climates and topographies that cause variability.

\subsubsection{Chemical stressors in the environment}

Compared to large grain sizes, finer sediment (silt, clay) have a wellestablished relationship with metals and contaminants (Baptista-Salazar \& 
Biester, 2019; Marasinghe Wadige, Taylor, Krikowa, \& Maher, 2016; Wuana \& Okieimen, 2014). Metals adsorb more readily to fine grains due to physiochemical properties, such as texture (silt/clay), chemical make-up, $\mathrm{pH}$, organic carbon (\%OC), cation exchange capacity, and moisture (Wuana \& Okieimen, 2014). Metals bound to sediment can be transported (Baptista-Salazar \& Biester, 2019; Castro-Larragoitia, Kramar, Monroy-Fernández, Viera-Décida, \& García-González, 2013) and accumulate in downstream catchments (Schertzinger, Ruchter, \& Sures, 2018; J. N. Smith \& Schafer, 1999). They have a potential to leach, mobilize, and become bioavailable and therefore these metals concentrations should be screened. Alterations to sedimentation can foster increased metal contamination (Balunger \& Mckee, 2009; Marasinghe Wadige et al., 2016). The impacts on riverine and estuarine environments from geomorphic variability is exacerbated in semi-arid, coastal watersheds because they are 1) naturally low in infiltration capacity (Hawley \& Bledsoe, 2011; Jodar-Abellan, Valdes-Abellan, Pla, \& Gomariz-Castillo, 2019) and 2) have a high market for development (Conway, 2005; Hogan, 2002; Miguez et al., 2019) and therefore increased anthropogenic runoff.

Studies have found that higher concentrations of Cadmium (Cd), Copper $(\mathrm{Cu})$, Lead $(\mathrm{Pb})$, Zinc ( $\mathrm{Zn})$ (Marasinghe Wadige et al., 2016) and Mercury (Hg) (Baptista-Salazar \& Biester, 2019) were in clay or silt bottom sediments by pointsource sites (including mines or industrial locations), and persisted post flood and even following remediation efforts. Locations for high $\mathrm{Hg}$ concentrations could be attributed to streamflow and sedimentation patterns (Baptista-Salazar \& 
Biester, 2019). Methyl-mercuration and metals persisting in toxic quantities pose a risk of bioavailability for organismal uptake.

In 2011, Los Peñasquitos Creek was identified as impaired under the Clean Water Act due to total dissolved solids (TDS) and phosphate stressors from urban runoff, sewage, spills, landfill leachate, dredging, and natural sources (City of San Diego, 2011). Other water quality models have been used (based on landuse, meteorological data, and watershed segmentation) to estimate total suspended solids, total nitrogen and phosphorus, total $\mathrm{Cu}, \mathrm{Pb}$, and $\mathrm{Zn}$, and coliform (fecal, total, and Enterococcus) (City of San Diego, 2015). Coastal Southern California regions contain elevated background levels of phosphorus and some metals from local geology. In fact, up to $25 \%$ comes from cultivated land and point sources (Domagalski \& Saleh, 2015). Jarvie, Neal, \& Withers (2006) found that sewage and point-source phosphorus, transported by runoff, had a greater impact on river eutrophication than agricultural sources. Water quality and river morphology is therefore likely influenced by rising populations due to the runoff delivery of chemical stressors, flow, and sediment (Smith \& Kraft, 2013).

\subsubsection{Flooding and modeling flow}

In already semi-arid climates with low ground-permeability, storm events often cause flash floods. With urbanization, excess surface flow from storm drains and new impermeable surfaces changes the entire natural hydrograph by dramatically increasing the flow magnitude and shortening the lag time (Bierman \& Montgomery, 2020). One way to reduce flood risk is through management, such as zoning, building codes, flood insurance, non-structural measures, and 
structural measures (FEMA, n.d.). A benefit of estuaries in coastal regions is their ability to naturally manage flood by entrapment of sediment, metals, and debris before entering the ocean (Smith \& Schafer, 1999; Voynova, Brix, Petersen, Weigelt-krenz, \& Scharfe, 2017). However, the impact can have lasting effects on the estuarine environment from the overload (Voynova et al., 2017). Often in southern California coastal watersheds, the focus remains on estuaries because of the organisms and the low-risk to the few perennial channels flowing through mostly confined canyons. However, flooding in these open-space watersheds and preserves can endanger the ecosystem services they provide. To maintain, reclaim, or rebuild such areas is a lengthy and costly process. Flow modeling along a channel can be used to quantify and estimate the flood impact and identify geographic focal zones to help limit damages, costs, and loss. Previous studies have used hydrologic models to solve specific problems, such as relocating detention ponds (Kulkarni, Eldho, Rao, \& Mohan, 2014) and planning for future water resources with climate change (Meixner et al., 2016).

\subsubsection{Runoff modeling limitations}

The stochastic nature of hydrologic freshwater systems, the spatial variability, and the futuristic uncertainty make methodologies for modeling complex (Vinodkumar et al., 2017). Rational and empirical models have been employed to estimate runoff but assumptions must be made that limit or ignore many contributing factors (soil moisture, infiltration, drainage area, change in land use/land cover/roughness, slope, and antecedent precipitation) (Descroix, Nouvelot, \& Vauclin, 2002; Fletcher, Andrieu, \& Hamel, 2013; Koster, Guo, 
Yang, Dirmeyer, \& Mitchell, 2009; Salvadore, Bronders, \& Batelaan, 2015;

Sridhar, Billah, \& Hildreth, 2018; Vinodkumar et al., 2017). Therefore, modeled runoff and future projections are often on the conservative end (Vinodkumar et al., 2017). While every model is limited, the Antecedent Precipitation Index method takes soil saturation and a regional coefficient into account and has successfully estimated runoff from precipitation in climates similar to that of San Diego (Descroix et al., 2002; Nikas, Antonakos, Lambrakis, \& Kallergis, 2007).

\subsubsection{IPCC regional climate projections}

The Intergovernmental Panel on Climate Change (IPCC) provides emissions scenarios and assessments based on world population trends. Scenarios are provided through approximate Representative Concentrations Pathway (RCP) around 2100. The most used scenarios for radiative forcing are RCP 2.6, 4.5, 6, and $8.5 \mathrm{~W} / \mathrm{m}^{2}$. Under RCP 2.6 , carbon dioxide $\left(\mathrm{CO}_{2}\right)$ radiative forcing peaks by 2050 and returns to $2.6 \mathrm{~W} / \mathrm{m}^{2}$ by 2100 . RCP 4.5 and 6.0 are intermediate, stabilization scenarios that approximate $1.1^{\circ} \mathrm{C}-2.6^{\circ} \mathrm{C}\left(4.5 \mathrm{~W} / \mathrm{m}^{2}\right)$ and $1.4^{\circ} \mathrm{C}-3.1^{\circ} \mathrm{C}$ $\left(6.0 \mathrm{~W} / \mathrm{m}^{2}\right)$ at the end of the $21^{\text {st }}$ century and constant concentrations after 2150. RCP 8.5 is the "business-as-usual" scenario that approximates $8.5 \mathrm{~W} / \mathrm{m}^{2}$ at the end of the $21^{\text {st }}$ century, constant emissions post 2250 , and increases the global temperature from $2.6^{\circ} \mathrm{C}-4.8^{\circ} \mathrm{C}$ ("IPCC, 2013: Summary for Policy Makers," 2013).

While the IPCC emission scenarios are based on global trends, regional climate monitoring and modeling efforts have been made. Messner et al. (2011) analyzed three climate models and two energy consumption and greenhouse-gas 
emissions scenarios. These also have uncertainty, but the results indicate that the current regional plans are not prepared for future conditions with the drier atmosphere and the variability of rainfall. The projections showed that precipitation cannot be modeled with consistency due to storminess with added variability from El Nino/Southern Oscillation patterns (Messner et al., 2011; van Oldenborgh, Doblas-Reyes, Wouters, \& Hazeleger, 2012). Therefore, the region is going to be considerably vulnerable to drought conditions which tie in directly to watershed and water management. The effects of climate change may be exacerbated by anthropogenic forcing which should be of further concern because the San Diego population is projected to rise $10 \%$ by 2035 and another $10 \%$ by 2050, ultimately reaching around 4.5 million people (SANDAG, 2010).

\subsection{Aims of this study}

Previous sedimentary and water quality studies for this watershed are focused on total sediment or suspended solid loads into the estuary (City of San Diego, 2011, 2015; Tetra Tech Inc., 2016; Weston Solutions Inc., 2009). Previous modeled or calculated flows were undertaken with a civil engineering intent (California Department of Transportation, 2009) or to confirm that riparian growth has increased due to urbanization (White \& Greer, 2006). The studies conducted thus far do not quantify variables longitudinally along the creek that are specific enough for preserve management. The primary aim of this study is to establish baseline characteristics at Los Peñasquitos Creek for longitudinal river characteristics and river profiles, water and soil quality, and surface-water hydrology to assist watershed management in sustaining its ecosystem services 
and model future flow scenarios to improve long-term planning. Moreover, this study's intent is to emphasize the importance of geomorphic contributions to geochemical and climatic studies for a more holistic approach to future work and management in small, coastal, densely-urbanized watersheds in semi-arid climates. The overall objective of this thesis is to quantify the distribution of total metals, nutrients, and organic carbon along Los Peñasquitos Creek and evaluate how channel morphology and repeated flood inundations may contribute to the distribution patterns and how this information can support monitoring and management of the area. To do so, I answer the following research questions:

1. How do the river morphological characteristics (channel width, depth, flow, and grain size) vary longitudinally within LPC?

2. How does the distribution of metals, phosphate, and organic carbon vary spatially (longitudinally and laterally) and what is the relationship between these parameters, water quality variables (barometric pressure, dissolved oxygen, conductivity, salinity, $\mathrm{pH}$, turbidity, temperature) and river characteristics?

3. What is the relationship between rainfall and peak flows at Los Peñasquitos Creek?

4. Where does flood inundation occur at LPC under different recurrence intervals (RI-5, 10, 20, 50, 100) and climatic scenarios (IPCC RCP 2.6, 4.5, 6.0 and 8.5$) ?$ 


\section{$1.4 \quad$ Structure of thesis}

Research questions 1-2 are presented in Chapter 2, while research questions 3-4 are presented in Chapter 3. Chapters 2 and 3 are written as manuscripts for publication and both intend to inform future research as well as the Peñasquitos Watershed management team (Cities of San Diego, City, Poway, Del Mar, County of San Diego, and California Department of Transportation). Supplementary data, figures, and analyses are collated in the appendices of this thesis. 


\subsection{References}

Balunger, D. G., \& Mckee, G. D. (2009). Chemical Characterization of Bottom Sediments. Bottom Sediment, 43(2), 216-227.

Baptista-Salazar, \& Biester, H. (2019). The Role of Hydrological Conditions for Riverine Hg Species Transport in the Idrija Mining Area. Environmental Pollution, 247, 716-724. https://doi.org/10.1016/j.envpol.2019.01.109

Bennett, M. (2018). Quantifying the Effects of Watershed Urbanization on the Hydrology and Channel Morphology in Los Peñasquitos Reserve.

[Conference Presentation Abstract].

Bierman, P. R., \& Montgomery, D. R. (2020). Drainage Basins. In Key Concepts in Geomorphology (2nd ed., pp. 239-270). New York: MacMillan Learning.

California Department of Transportation. (2009). Los Peñasquitos Creek Location Hydraulic Study. Retrieved from https://www.keepsandiegomoving.com/Documents/NCC_doc/EIR/Supportin g/3.09_Hydrology/Los_Peñasquitos_Creek_Location-Hydraulidc-StdyMar09.pdf

California Department of Transportation. (2015). Los Penasquitos Watershed Management Area Water Quality Improvement Plan and Comprehensive Load Reduction Plan (Permit Provision F.1.b). San Diego. Retrieved from https://www.sandiego.gov/sites/default/files/legacy/stormwater/pdf/PEN_Wa terQualityImprovementPlan_021715.pdf

Castro-Larragoitia, J., Kramar, U., Monroy-Fernández, M. G., Viera-Décida, F., \& García-González, E. G. (2013). Heavy Metal and Arsenic Dispersion in a Copper-Skarn Mining District in a Mexican Semi-Arid Environment: Sources, Pathways and Fate. Environmental Earth Sciences, 69(6), 19151929. https://doi.org/10.1007/s12665-012-2024-1

City of San Diego. (2011). Hydrology and Water Quality. Retrieved from https://www.sandiegocounty.gov/content/dam/sdc/pds/gpupdate/docs/BOS_ Aug2011/EIR/FEIR_2.08_-_Hydrology_2011.pdf

City of San Diego. (2015). Los Penasquitos WMA Water Quality Improvement Plan and Comprehensive Load Reduction Plan. San Diego. Retrieved from https://www.delmar.ca.us/ArchiveCenter/ViewFile/Item/455

Conway, T. M. (2005). Current and Future Patterns of Land-Use Change in the Coastal Zone of New Jersey. Environment and Planning B: Planning and Design, 32, 877-893. https://doi.org/10.1068/b31170

Descroix, L., Nouvelot, J., \& Vauclin, M. (2002). Evaluation of an Antecedent Precipitation Index to Model Runoff Yield in the Western Sierra Madre (North-West Mexico). Journal of Hydrology, 263, 114-130.

Domagalski, J., \& Saleh, D. (2015). Sources and Transport of Phosphorus to Rivers in California and Adjacent States, U.S., as Determined by Sparrow Modeling 1. Journal of the American Water Resources Association, 51(6), 1463-1486. https://doi.org/10.1111/1752-1688.12326

FEMA. (n.d.). All About Flood Maps. Retrieved October 18, 2019, from https://www.floodsmart.gov/why/all-about-flood-maps 
Fletcher, T. D., Andrieu, H., \& Hamel, P. (2013). Understanding, Management and Modelling of Urban Hydrology and Its Consequences for Receiving Waters: A State of the Art. Advances in Water Resources, 51, 261-279. https://doi.org/10.1016/j.advwatres.2012.09.001

Hawley, R. J., \& Bledsoe, B. P. (2011). How Do Flow Peaks and Durations Change in Suburbanizing Semi-Arid Watersheds? a Southern California Case Study. Journal of Hydrology, 405(1-2), 69-82. https://doi.org/10.1016/j.jhydrol.2011.05.011

Hogan, R. (2002). The Failure of Planning: Permitting Sprawl in San Diego Suburbs, 1970-1999.

IPCC, 2013: Summary for Policy Makers. (2013). Climate Change: The Physical Science Basis. Contribution of Working Group I to the Fifth Assessment Report of the Intergovernmental Panel on Climate Change [Stocker, T.F., D. Qin, G.-K. Plattner, M. Tignor, S.K. Allen, J. Boschung, A. Nauels, Y. Xia, V. $B$.

Jarvie, H. P., Neal, C., \& Withers, P. J. A. (2006). Sewage-Effluent Phosphorus: A Greater Risk to River Eutrophication Than Agricultural Phosphorus? Science of the Total Environment, 360, 246-253. https://doi.org/10.1016/j.scitotenv.2005.08.038

Jodar-Abellan, A., Valdes-Abellan, J., Pla, C., \& Gomariz-Castillo, F. (2019). Science of the Total Environment Impact of Land Use Changes on Flash Flood Prediction Using a Sub-Daily SWAT Model in Five Mediterranean Ungauged Watersheds (SE Spain). Science of the Total Environment, 657, 1578-1591. https://doi.org/10.1016/j.scitotenv.2018.12.034

Koster, R. D., Guo, Z., Yang, R., Dirmeyer, P. A., \& Mitchell, K. (2009). On the Nature of Soil Moisture in Land Surface Models. Journal of Climate, 22, 4322-4336. https://doi.org/10.1175/2009JCLI2832.1

Kulkarni, A. T., Eldho, T. I., Rao, E. P., \& Mohan, B. K. (2014). An Integrated Flood Inundation Model for Coastal Urban Watershed of Navi Mumbai, India. Natural Hazards, 73, 403-425. https://doi.org/10.1007/s11069-0141079-6

Leopold, L. B., \& Maddock, T. (1953). The Hydraulic Geometry of Stream Channels and Some Physiographic Implications. Geological Survey. Washington, D.C. Retrieved from https://pubs.usgs.gov/pp/0252/report.pdf

Marasinghe Wadige, C. P. M., Taylor, A. M., Krikowa, F., \& Maher, W. A. (2016). Sediment Metal Concentration Survey Along the Mine-Affected Molonglo River, NSW, Australia. Archives of Environmental Contamination and Toxicology, 70(3), 572-582. https://doi.org/10.1007/s00244-015-0259-z

Mazor, R. D., Mccune, S., May, J. T., Bledsoe, B. P., \& Stein, E. D. (2018). Tools for Managing Hydrologic Alteration on a Regional Scale: Setting Targets to Protect Stream Health. Freshwater Biology, (December 2017), 786-803. https://doi.org/10.1111/fwb.13062

Meixner, T., Manning, A. H., Stonestrom, D. A., Allen, D. M., Ajami, H., Blasch, K. W., ... Walvoord, M. A. (2016). Implications of Projected Climate Change for Groundwater Recharge in the Western United States. Journal of Hydrology, 534, 124-138. https://doi.org/10.1016/j.jhydrol.2015.12.027 
Messner, S., Miranda, S. C., \& Young, E. (2011). Climate Change-Related Impacts in the San Diego Region by 2050. Climate Change, 109(Suppl 1), 505-531. https://doi.org/10.1007/s10584-011-0316-1

Miguez, M. G., Verol, A. P., Battemarco, B. P., Yamamoto, L. M. T., Almeida de Brito, F., Fernandez, F. F., ... Rego, A. Q. (2019). A Framework to Support the Urbanization Process on Lowland Coastal Areas: Exploring the Case of Vargem Grande E Rio de Janeiro, Brazil. Journal of Cleaner Production, 231, 1281-1293. https://doi.org/10.1016/j.jclepro.2019.05.187

Nikas, K., Antonakos, A., Lambrakis, N., \& Kallergis, G. (2007). The Use of "Antecedent Precipitation Index" and "Delay Factor" to Estimate Runoff From Rainfall; A Case Study From Eight Drainage Basins-Achaia, Peloponessos, Greece. Bulletin of the Geological Society of Greece, 37(June 2015).

Phillips, J. D., \& Slattery, M. C. (2007). Downstream Trends in Discharge, Slope, and Stream Power in a Lower Coastal Plain River, 290-303. https://doi.org/10.1016/j.jhydrol.2006.10.018

Salvadore, E., Bronders, J., \& Batelaan, O. (2015). Hydrological Modelling of Urbanized Catchments: A Review and Future Directions. Journal of Hydrology, 529(P1), 62-81. https://doi.org/10.1016/j.jhydrol.2015.06.028

SANDAG. (2010). 2050 Regional Growth Forecast: Process and Model Documentation.

Schertzinger, G., Ruchter, N., \& Sures, B. (2018). Metal Accumulation in Sediments and Amphipods Downstream of Combined Sewer Over Flows. Science of the Total Environment, 616-617, 1199-1207. https://doi.org/10.1016/j.scitotenv.2017.10.199

Smith, B. F., \& Kraft, J. R. (2013). A Cultural Resources Study for the Los Peñasquitos Adobe Drainage Project, San Diego County, California (CSD04.03). San Diego. Retrieved from https://www.sandiegocounty.gov/reusable_components/images/dgs/Documen ts/CEQA_LPAdobeExhibitB.pdf

Smith, J. N., \& Schafer, C. T. (1999). Sedimentation , Bioturbation , and Hg Uptake in the Sediments of the Estuary and Gulf of St . Lawrence. Limnology and Oceanography, 44(1), 207-219.

Sridhar, V., Billah, M. M., \& Hildreth, J. W. (2018). Coupled Surface and Groundwater Hydrological Modeling in a Changing Climate. Groundwater, 56(4), 618-635. https://doi.org/10.1111/gwat.12610

Taniguchi, K. T., \& Biggs, T. W. (2015). Geomorphology Regional Impacts of Urbanization on Stream Channel Geometry: A Case Study in Semiarid Southern California. Geomorphology, 248, 228-236. https://doi.org/10.1016/j.geomorph.2015.07.038

Tetra Tech Inc. (2016). Sediment Load Reduction Quantification through Outfall Repair and Relocation for the Los Penasquitos WMA. San Diego.

van Oldenborgh, G. J., Doblas-Reyes, F. J., Wouters, B., \& Hazeleger, W. (2012). Decadal Prediction Skill in a Multi-Model Ensemble. Climate Dynamics, 38, 1263-1280. https://doi.org/10.1007/s00382-012-1313-4

Vinodkumar, Dharssi, I., Bally, J., Steinle, P., McJannet, D., \& Walker, J. (2017). 
Comparison of Soil Wetness from Multiple Models Over Australia with Observations. Water Resources Research, 53, 633-646.

https://doi.org/10.1002/2015WR017738.Received

Voynova, Y. G., Brix, H., Petersen, W., Weigelt-krenz, S., \& Scharfe, M. (2017). Extreme Flood Impact on Estuarine and Coastal Biogeochemistry: The 2013 Elbe Flood. Biogeosciences, 14, 541-557. https://doi.org/10.5194/bg-14-5412017

Weston Solutions Inc. (2009). Los Peñasquitos Lagoon TMDL - Watershed Phase I Sediment Source Identification Study Watershed Phase I Sediment Source Final Report. Retrieved from https://www.sandiego.gov/sites/default/files/lospensedimentstudy.pdf

White, M. D., \& Greer, K. A. (2006). The Effects of Watershed Urbanization on the Stream Hydrology and Riparian Vegetation of Los Peñasquitos Creek, California. Landscape and Urban Planning, 74(2), 125-138. https://doi.org/10.1016/j.landurbplan.2004.11.015

Wuana, R. A., \& Okieimen, F. E. (2014). Heavy Metals in Contaminated Soils: A Review of Sources, Chemistry, Risks, and Best Available Strategies for Remediation. Heavy Metal Contamination of Water and Soil: Analysis, Assessment, and Remediation Strategies, 2011, 1-20. https://doi.org/10.1201/b16566 


\section{CHAPTER 2: QUANTIFYING LONGITUDINAL VARIATION IN FLUVIAL MORPHOLOGY, METALS, AND NUTRIENTS OF LOS PEÑASQUITOS CREEK, SAN DIEGO COUNTY, CA}

This chapter has been formatted for publication in the journal Physical Geography.

\subsection{Abstract}

Rivers in semi-arid climates are directly influenced by local geographic and hydrologic conditions and impacted by modifications to hydrology via urbanization. Changes can influence erosion, morphology, habitat sustainability, and watershed health. In highly urbanized southern California coastal regions, these rare open spaces provide vital ecosystem services. Los Peñasquitos Creek in San Diego County is one such watershed. Using stream surveying and laboratory methods we quantified channel characteristics, grain size distribution, total metal concentration $[\mathrm{M}]$, organic carbon (\%OC), and phosphate to longitudinally characterize the creek for improved management. Results identified three distinct reaches in the watershed (upper, middle, lower). Downstream, depth and velocity are inversely related $\left(R^{2}:-0.86\right)$, while grain size decreases (D50:45mm-0.2mm), influenced by slope-driven widening and overbank deposition in the middle reach. Phosphate and $[\mathrm{M}]$ vary, likely influenced by anthropogenic runoff. Data suggests that \%OC (instead of grain size) is more strongly correlated with [M] overall, especially zinc and lead, and is influenced by riparian zone vegetation density. This study emphasizes the importance of local and geomorphic influences on geochemical variability. Suggestions include 5-year or drought year $\mathrm{Cu}, \mathrm{Hg}, \mathrm{Pb}$, 
Zn monitoring (exceeded SQuirT screening) at specific sites and continued nutrient analysis for eutrophication at the confluence.

KEYWORDS: Fluvial Geomorphology, Coastal Watershed, Hydrology, Downstream Trends, Environmental Chemistry

\subsection{Introduction}

A watershed consists of a primary river, its network of connected tributaries and the surrounding land. Rivers and their watersheds globally provide necessary economic (water, jobs, food, tourism, hydroelectricity, transport, arable land), cultural (open spaces, recreation, tourism), and ecological (habitat, refuge, food source, nutrient transport) services (Bridge, 2003). Natural and anthropogenic changes in river systems can cause detrimental changes to hydrologic resources and the ecosystem (Bridge, 2003; Du et al., 2012). The impact of these hydrologic changes is more pronounced in small coastal watersheds where headwaters are closely linked to the downstream wetlands, such as estuaries. Estuarine ecosystems are directly and indirectly impacted by geomorphic changes upstream (Hawley \& Bledsoe, 2013; Neeson, Gorman, Whiting, \& Koonce, 2008). This is particularly true for alterations to sedimentation (Birtwell, 1999; Ejarque et al., 2017) and streamflow from both land-use change (such as urbanization) and climate change (Fletcher, Andrieu, \& Hamel, 2013; Stein, Mazor, Mccune, Bledsoe, \& Adams, 2017; Voynova, Brix, Petersen, Weigelt-krenz, \& Scharfe, 2017). Furthermore, alterations to sedimentation can foster increased metal contamination (Balunger \& Mckee, 2009; Marasinghe Wadige, Taylor, Krikowa, \& Maher, 2016). The impacts on riverine and estuarine environments from geomorphic variability is exacerbated in 
semi-arid, coastal watersheds because they are 1) naturally low in infiltration capacity (Hawley \& Bledsoe, 2011; Jodar-Abellan, Valdes-Abellan, Pla, \& Gomariz-Castillo, 2019) and 2) have a high market for development (Conway, 2005; Hogan, 2002; Miguez et al., 2019).

\subsubsection{Geomorphology and Sedimentation}

Geomorphic river characteristics are quantified by width, depth, velocity, sediment load, and water discharge (or 'flow', $Q$ ) in a river cross section and over the channel reach (Leopold \& Maddock, 1953). The relationship between these parameters can be used to understand channel dynamics and deposition of material. Several factors, including slope, channel shape, water volume, and roughness influence the velocity of water (Ames, 2018), which in turn influence deposition and discharge (Bierman \& Montgomery, 2020). Often, the headwater channels are narrow, rapid, low flow with a steeper channel gradient, and contain larger heterogeneous gravel. As slope decreases downstream, the channel grows wide, deep, increases in flow volume, and becomes finer in grain size (Bierman \& Montgomery, 2020). Consequently, metal contaminants can more readily adsorb to those fine sediments (Wuana \& Okieimen, 2014) or be transported (BaptistaSalazar \& Biester, 2019; Castro-Larragoitia, Kramar, Monroy-Fernández, VieraDécida, \& García-González, 2013) and accumulate downstream (Schertzinger, Ruchter, \& Sures, 2018; J. N. Smith \& Schafer, 1999). However, geography, climate, and upstream inputs can alter these common patterns (Hawley \& Bledsoe, 2013; Phillips \& Slattery, 2007), making it critical to incorporate local channel morphology in monitoring programs. 


\subsubsection{Contaminants}

Metals and fine particle size typically have a linear relationship due to adsorption influenced by mineralogical and physiochemical properties (Wuana \& Okieimen, 2014). In addition, point-source can also have an impact on concentrations (Castro-Larragoitia et al., 2013; Reza, Islam, Mia, Khan, \& Habib, 2020). Historical mining sites exist throughout San Diego. Contaminants from historical mines or general upstream activity can be introduced in waterways and sediment deposited may be mobilized, flushed downstream during high flow events, and spread metal contamination in soluble or particulate form (Brooks \& Moore, 1989). In New South Wales, Australia, (Marasinghe Wadige et al., 2016) found that high concentrations of Cadmium $(\mathrm{Cd})$, Copper $(\mathrm{Cu})$, Lead $(\mathrm{Pb})$, Zinc ( $\mathrm{Zn})$ were found at sites close to a point-source mine and in silt and clay bottom sediments in the Molonglo River. Baptista-Salazar \& Biester (2019) attributed higher concentrations of Mercury $(\mathrm{Hg})$ in bottom and bank sediments to streamflow and sedimentation patterns in the Idrijca River, Slovenia. Both studies also found that contamination persisted post flood and even following remediation efforts. Freshwater organisms at sites with potential contamination in bioavailable forms could therefore consequently uptake metals and nutrients in toxic quantities. Total trace metal concentration [M] (consisting of all metal forms) in bottom sediment can be a good proxy for baseline assessment (Makinde et al., 2016) prior to mobile metal and bioavailable studies.

Dissolved phosphate, or orthophosphate-P, from anthropogenic loads (sewage, industrial, agricultural) reduces water quality in rivers and catchments 
(Tappin, Comber, \& Worsfold, 2016). Although coastal Southern California regions contain elevated background levels of phosphorus (P) from local geology, up to $25 \%$ comes from cultivated land and point sources close to the coast (Domagalski \& Saleh, 2015). A study by Jarvie, Neal, \& Withers (2006) found that point-source $\mathrm{P}$ from sewage effluent causes greater risk to river eutrophication compared to diffuse sources (agricultural). Diffuse-source P is transported by runoff, while Soluble Reactive Phosphorus (SRP) is removed by bed sediment during the low flow season (Jarvie et al., 2006; Tappin et al., 2016).

Rising populations may therefore have an impact on water quality and river morphology with increased development and anthropogenic runoff delivering chemicals, larger flow volume, and sediment to the watershed (Smith $\&$ Kraft, 2013). In addition to sediment accretion and movement of chemicals, nutrients, and debris, excess surface flow on impermeable surfaces and increased input from storm drains result in flash flooding and erosion (Bierman \& Montgomery, 2020). With population continuing to rise in limited open-space coastal watersheds (Conway, 2005), it is important to determine baseline measures and areas of risk to better prepare for watershed function and sustainability (Gober, 2010).

\subsubsection{Study Area}

Los Peñasquitos Creek is central to San Diego County, which lies in the south-western most province of California $\left(32.30-33^{\circ} \mathrm{N}, 117-118^{\circ} \mathrm{W}\right)$ between the Pacific Ocean (west) and part of the Peninsular Mountain Range (east). Climate in San Diego is characterized as semi-arid, Mediterranean $\left(50-80^{\circ} \mathrm{F}\right)$ with 
dry, hot summers and cool, wet winters (“California Climate Zone 7,” 1963). Annual precipitation $(\mathrm{P})$ averages between $25.5-30.5 \mathrm{~cm}(10-12$ in) with the greatest stream flow/discharge (Q) occurring between December - March (Figure 2.1). Despite $Q$ reflecting $P$, it is unusual for precipitation this low to cause annually flowing freshwater.

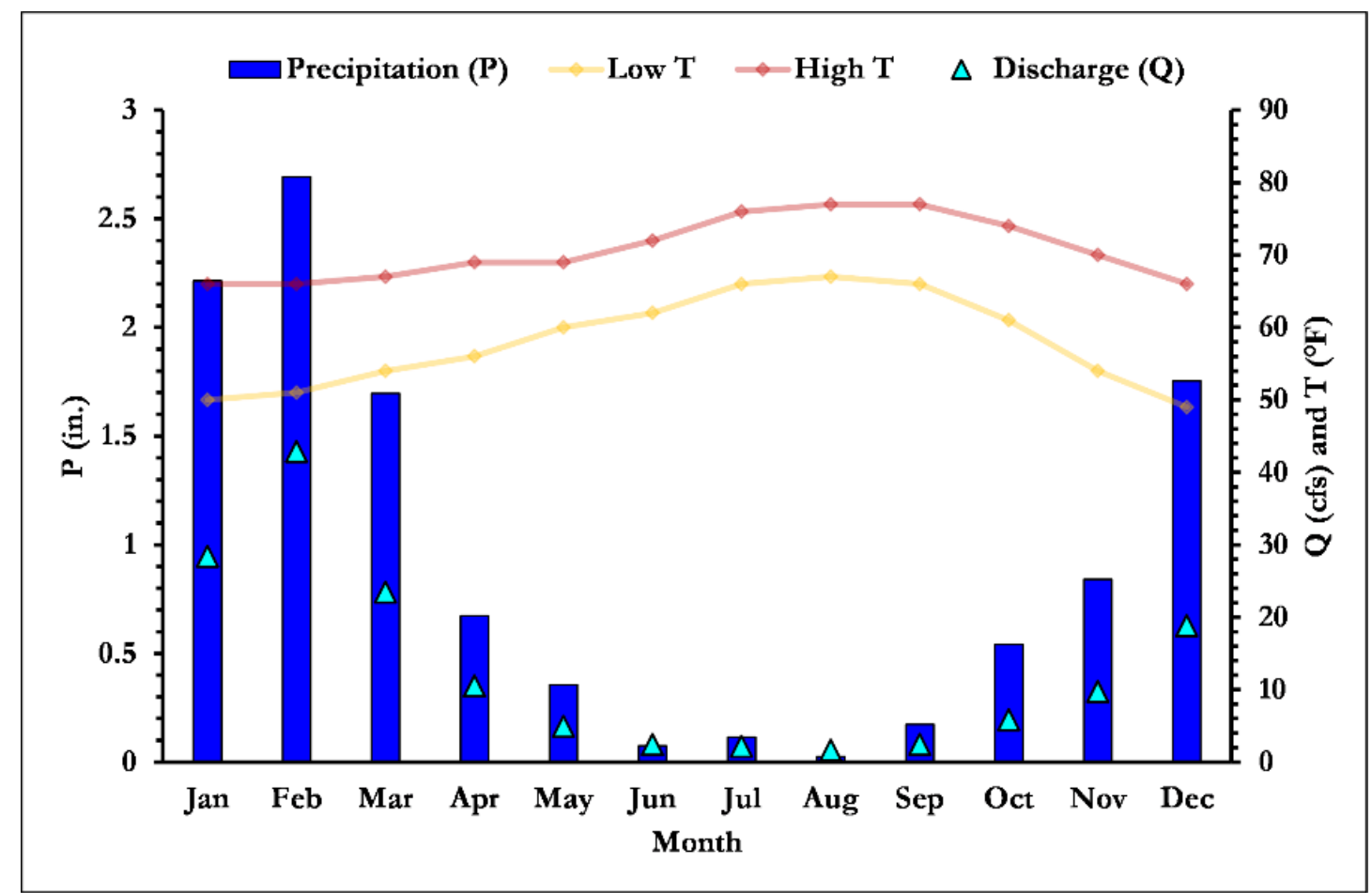

Figure 2.1 Local monthly averages (1989-2019) for climate variables: precipitation, temperature $(\mathrm{T}), \&$ discharge.

In fact, Los Peñasquitos Creek flow was historically intermittent due to these climatic conditions but is now perennial due to changes in land use/land cover (LU/LC) (Smith \& Kraft, 2013; White \& Greer, 2006). The creek flows through two canyons and feeds into the Los Peñasquitos Lagoon (LPL), a coastal wetland that is critical habitat for aquatic organisms (Greer \& Stow, 2003). Changes in discharge, or freshwater flow, have contributed to changes in salinity (Greer \& Stow, 2003), while changes in sediment (e.g. grain size, sediment load) 
contribute to leachability of pollutants and turbidity (California Regional Water Quality Board, 2011; Weston Solutions Inc., 2009). Along with land use and climate, variability in flow and sediment alters hydraulic variables that impact erosion, morphology, and the ability to sustain riverine habitat stability (Birtwell, 1999; Leopold \& Maddock, 1953; Voynova et al., 2017). In addition, Los Peñasquitos Lagoon and lower creek are especially sensitive to the effects of pollutants due to restricted or intermittent tidal flushing (California Department of Transportation, 2009). Of the several historic mines, one reclaimed arsenic mine at Black Mountain Park lies just north of a Los Peñasquitos Creek tributary, but feeds into Lusardi Creek and La Zanja canyon (M.W. Steele Group, Rick Planning Group, \& Stepner, 2006) in San Dieguito River Basin, north of Carmel Valley subwatershed (Figure 2.2). While arsenic has been researched on site (Wright, 2021), the potential contamination into the south side of the mountain and Los Peñasquitos has not been assessed. 


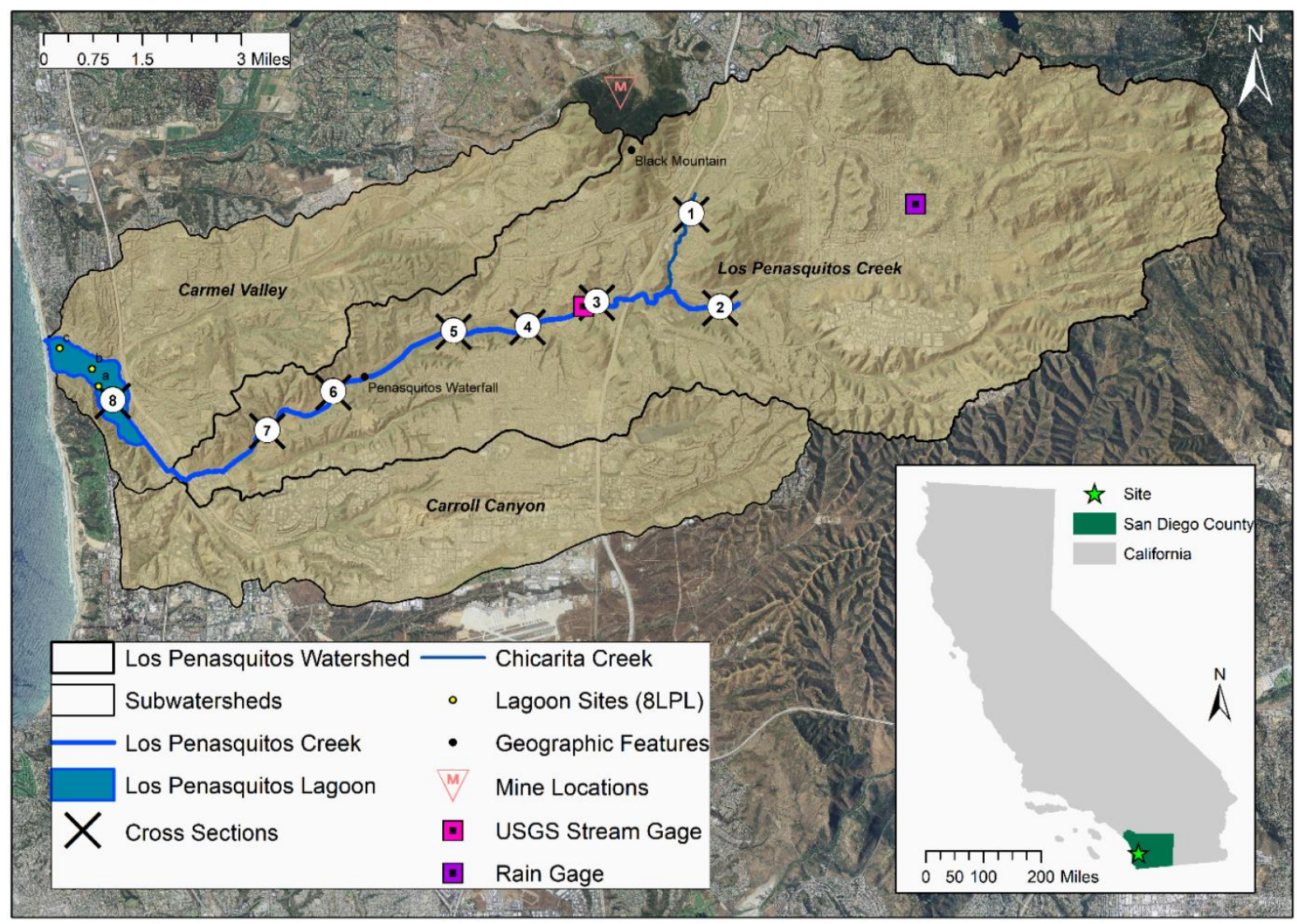

Figure 2.2 Los Peñasquitos watershed in San Diego County, CA, is comprised of three sub-watersheds, Carmel Valley, Los Peñasquitos Creek, and Carroll Canyon. This research focuses on the cross-sections within the Los Peñasquitos Creek subwatershed along the creek.

Additionally, limited water quality reports and land cover studies have been conducted in the Los Peñasquitos Creek and sub watershed (California Regional Water Quality Board, 2011; San Diego Coastkeeper, 2010; Smith \& Kraft, 2013; Weston Solutions Inc., 2009; White \& Greer, 2006). Currently, there are no established ranges quantified for channel morphology, total metals, or nutrients. To inform watershed management and improve monitoring, this study aims to (1) quantify river characteristics longitudinally for hydraulic parameters including velocity, channel width, depth, and discharge and (2) quantify the 
distribution of metals, phosphate, and organic carbon and identify the relationships between these and changes in sediment grain size and local features.

\subsection{Materials and Methods}

\subsubsection{Field Methods: Site selection, surveying, and sampling}

The six sampling sites mapped along the main channel (Figure 2.2) were selected based on longitudinal distribution and accessibility of the sites. An additional tributary was surveyed and sampled to quantify geochemical influence from Black Mountain, an abandoned and reclaimed arsenic mining site. Eight sampling locations were also selected in LPL to assess upstream influence. At each site, 1-3 cross-sections, depending on accessibility were surveyed using an RTK R10 Trimble GNSS and ground-truthed with an auto level. Channel slopes were also calculated from 3-meter 2016 DEM-extracted Elevation (Z)-values over $1 \mathrm{~km}$ reaches (500 $\mathrm{m}$ up and downstream each sampling site) in the river (Table 2.1). Surveying and sampling occurred over two weeks in June of 2019 and the stream gage (USGS 11023340) readings ranged from $0.038-0.083 \mathrm{cms}$ during this period (refer to Appendix A for sampling dates and mean daily discharge values).

A total of 80 sediment samples, both channel grab samples (CGS) and bank grab samples (BGS), along with 50 water samples for phosphate analysis, were collected along cross-sections during river low-flow conditions (Bunte \& Abt, 2001). The samples were labeled, and stored or pre-processed for analysis (Ejarque et al., 2017; Xun \& Xuegang, 2015). Water quality parameters 
(barometric pressure, dissolved oxygen, conductivity, salinity, $\mathrm{pH}$, turbidity, temperature) were measured using a YSI ProDSS in the channel center.

\subsubsection{Lab Methods}

\subsubsection{Particle Size}

All samples were frozen, thawed, spread evenly, and dried at $105^{\circ} \mathrm{C}$. Larger organic debris (seashells, twigs, leaves, dried algae) greater than $4 \mathrm{~mm}$ was removed. The remaining sample was dissociated with a mortar-pestle, weighed, and sieved (through $4 \mathrm{~mm}, 2 \mathrm{~mm}, 1 \mathrm{~mm}, 0.5 \mathrm{~mm}, 0.25 \mathrm{~mm}, 0.125 \mathrm{~mm}$, $0.063 \mathrm{~mm}$ sieves). A subsample of the fine fraction was removed and homogenized for fine grain size analysis, run on a Cilas 1190 Particle Size Analyzer and metal analysis. The fine fraction included coarse sand (>1mm), medium sand $(>0.5 \mathrm{~mm})$, fine sand $(>0.25 \mathrm{~mm})$, very find sand $(>0.125 \mathrm{~mm})$, silt $(>0.063 \mathrm{~mm})$, and clay $(<0.063 \mathrm{~mm})$ (Marasinghe Wadige et al., 2016). The gravel grab samples were additionally sieved through sieves $16 \mathrm{~mm}$ to $0.063 \mathrm{~mm}$. A gravelometer was used to group pebbles and cobbles $>16 \mathrm{~mm}$ diameter for an additional $5 \mathrm{CGS}(1 \mathrm{CH}, 2 \mathrm{SB}, 3 \mathrm{VC}, 4 \mathrm{CA}, 5 \mathrm{SA}$ (Figure 2.2). The pebbles and cobbles were weighed, and these weights were combined with the other CGS data to plot the grain size distribution at each site.

\subsubsection{Regulatory Thresholds}

\section{Metal Analysis}

The subsample was homogenized again for total metal concentration, [M], analysis via Innovex X-5000 X-ray fluorescence (XRF) (Makinde et al., 2016) and run in sextuplicate to account for sample heterogeneity. While all Title 22 
metals (As, Ag, Ba, Be, Cu, Cd, Co, Cr (Total), Cr+6, Hg, Mo, Ni, Pb, Se, Ti, V, and $\mathrm{Zn}$ ) were measured, Arsenic (As), Cadmium (Cd), Chromium (Cr), Copper $(\mathrm{Cu})$, Mercury $(\mathrm{Hg})$, Lead $(\mathrm{Pb})$, and Zinc $(\mathrm{Zn})$ were metals of interest, being commonly used for comparison with other contamination analysis research (Wuana \& Okieimen, 2014).

Organic Carbon

Organic Carbon (OC) was measured by loss-on-ignition (Hoogsteen, Lantinga, Bakker, Groot, Tittonell, 2015; Miller et al., 2014; Sutherland, 1998). Three samples, in triplicates containing $3 \mathrm{~g}$ each, were ignited in the furnace at $550^{\circ} \mathrm{C}$ for 4 hours to burn off OC. After 30 minutes of desiccant drying, sample weight difference was recorded to calculate $\% \mathrm{OC}$.

Phosphate (PO4)

Orthophosphate in creek water samples was screened in parts per million (ppm) using a PhosVer $3 \mathrm{PO}_{4}$ Reagent in $5 \mathrm{~mL}$ pipetted triplicates (3 readings each) on a Genesys 150 UV-Visible Spectrophotometer using USEPA PhosVer 3® (Ascorbic Acid) Method 8048 (USEPA, 2017)

\subsubsection{Statistical Methods}

We calculated sorting (Table 2.2) using the geometric (modified) (Folk \& Ward, 1957) graphical measures equation of standard deviation (Blott \& Pye, 2001; Walther, 2016):

$$
\sigma=\exp \left(\frac{(\ln D 16-\ln D 84)}{4}+\frac{(\ln D 5-\ln D 95)}{6.6}\right)
$$

where $D_{i}$ is the grain size diameter in mm of the ith percentile. Box plots and $95 \%$ Upper Confidence Limit (UCL) for metals (As, $\mathrm{Cr}, \mathrm{Cu}, \mathrm{Hg}, \mathrm{Pb}, \mathrm{Zn}$ ) in and out of 
channel were done using ProUCL 5.1, a comprehensive statistical software package developed by the US EPA for analyses of normal and non-normal distributed environmental datasets (USEPA, 2020). Correlation analysis in Microsoft Excel 2010 was used to quantify relationships between CGS and BGS for $[\mathrm{M}], \%$ Fine grain size $(\leq 2 \mathrm{~mm}$ and $\leq 0.063 \mathrm{~mm})$, and $\% \mathrm{OC}$. Ordinary Least Squares (OLS) regressions were also used between $[\mathrm{M}], \%$ Fine $(\leq 2 \mathrm{~mm})$, and $\% \mathrm{OC}$.

\subsection{Results}

\subsubsection{Channel Morphology}

At Los Peñasquitos Creek, the slope (S) differentiated the longitudinal profile of the study area into an upper $(\mathrm{S}=0.007)$, middle $(\mathrm{S}=0.005)$, and lower ( $\mathrm{S}=0.007)$ reach (Table 2.1). The slope for the entire length of the main channel (2SB-7PB) downstream is 0.008 while slopes at each site, decreases within reach

(Table 2.1). The downstream width (W) pattern resembles downstream discharge,

$\mathrm{Q}$ (Figure 2.3a). Water depth, $\mathrm{D}$, is inversely related to velocity, $\mathrm{V}\left(\mathrm{R}^{2}=0.743\right)$,

elevation, $\mathrm{Z}\left(\mathrm{R}^{2}=0.884\right)$ (Figure $\left.2.3 \mathrm{~b}\right)$, and width, $\mathrm{W}\left(\mathrm{R}^{2}=0.395\right)$.

Table 2.1 Channel parameters measured and calculated per cross-section (refer to Appendix B) at Los Peñasquitos Creek and Chicarita Tributary (1CH, in grey). The reaches, upper (2SB, 3VC), middle (4CA, 5SA), and lower (6SY, 7PB), are distinguished by the bolded black lines in the table below.

\begin{tabular}{|l|l|l|l|l|l|l|}
\hline Site & S & $\mathbf{W}(\mathbf{m})$ & $\mathbf{Q}(\mathbf{c m s})$ & $\mathbf{D}(\mathbf{m})$ & $\mathbf{V}(\mathbf{m s}-\mathbf{1})$ & $\mathbf{Z}$ \\
\hline 1CH & 0.019 & 2.10 & 0.206 & 0.08 & 0.245 & 155.65 \\
\hline 2SB & 0.006 & 2.70 & 0.122 & 0.13 & 0.215 & 111.27 \\
3VC & 0.002 & 6.48 & 0.147 & 0.22 & 0.073 & 83.48 \\
\hline 4CA & 0.005 & 6.13 & 0.123 & 0.13 & 0.170 & 70.73 \\
\hline 5SA & 0.005 & 14.33 & 0.163 & 0.21 & 0.141 & 59.43 \\
\hline 6SY & 0.011 & 12.80 & 0.120 & 0.41 & 0.027 & 24.25 \\
7PB & 0.002 & 7.00 & 0.084 & 0.62 & 0.023 & 15.59 \\
\hline
\end{tabular}



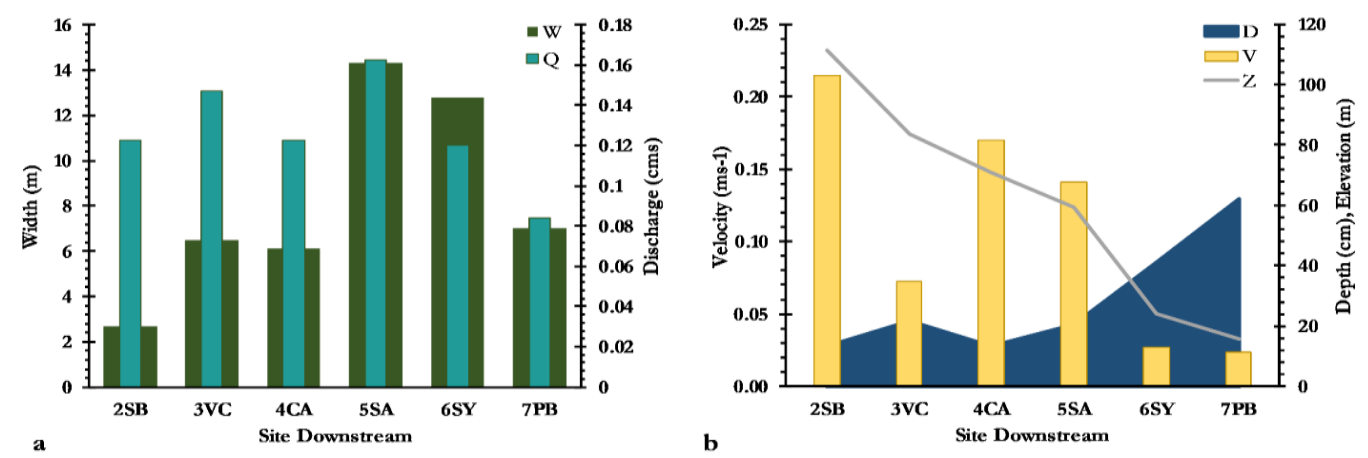

Figure 2.3 Channel parameters at each cross section along Los Peñasquitos creek. Downstream width (W), discharge (Q) (a) and downstream water depth (D), velocity (V), and elevation $(\mathrm{Z})(\mathrm{b})$

\subsubsection{Sediment}

The D50 values (Table 2.2) for CGS decrease downstream and range from $0.25 \mathrm{~mm}-45 \mathrm{~mm}$ (Figure 2.4b). BGS D50 are overall finer than CGS D50,

except at downstream sites where CGS and BGS are nearly the same, but slightly increase within each reach (Table 2.2).

Table 2.2 CGS Cumulative particle size $(\mathrm{mm})$ values for the $5^{\text {th }}, 16^{\text {th }}, 50^{\text {th }}, 84^{\text {th }}$, and $95^{\text {th }}$ percentiles. Sorting values $\left(\sigma_{\mathrm{s}}\right)$ for CGS show that all the sites are very well-sorted $\left(\sigma_{\mathrm{s}}<1.27\right.$ (Folk \& Ward, 1957)). Of the \%Fine $(\leq 2 \mathrm{~mm})$ and $\%$ Finer $(\leq 0.063 \mathrm{~mm})$, only CGS $\leq 2 \mathrm{~mm}$ increases downstream.

\begin{tabular}{|l|l|l|l|l|l|l|l|l|l|l|l|}
\hline Site & D5 & D16 & D50 & D84 & D95 & $\mathbf{\sigma}_{\text {s }}$ & $\begin{array}{l}\text { D50 } \\
\text { BGS }\end{array}$ & $\begin{array}{l}\text { CGS } \\
\leq \mathbf{2}\end{array}$ & $\begin{array}{l}\text { CGS } \\
\mathbf{\leq 0 . 0 6 3}\end{array}$ & $\begin{array}{l}\text { BGS } \\
\leq \mathbf{2}\end{array}$ & $\begin{array}{l}\text { BGS } \\
\mathbf{\leq 0 . 0 6 3}\end{array}$ \\
\hline $\mathbf{1}$ & 0.15 & 3 & 32 & 55 & 80 & 0.19 & 1.2 & 7.58 & 1.65 & 22.06 & 5.80 \\
$\mathbf{2}$ & 0.16 & 3.9 & 35 & 46 & 58 & 0.22 & 0.20 & 16.74 & 0.62 & 60.95 & 8.61 \\
$\mathbf{3}$ & 0.155 & 2.5 & 23 & 42 & 55 & 0.20 & 0.37 & 12.05 & 3.24 & 35.15 & 3.74 \\
$\mathbf{4}$ & 0.115 & 0.58 & 13 & 30 & 50 & 0.15 & 0.20 & 10.54 & 0.99 & 52.34 & 17.97 \\
$\mathbf{5}$ & 0.1 & 0.27 & 4.3 & 19.5 & 29 & 0.15 & 0.37 & 38.83 & 8.90 & 37.55 & 5.82 \\
$\mathbf{6}$ & 0.06 & 0.13 & 0.29 & 1 & 2.8 & 0.34 & 0.21 & 37.80 & 4.81 & 51.50 & 3.53 \\
$\mathbf{7}$ & 0.001 & 0.001 & 0.22 & 1.5 & 2.8 & 0.05 & 0.38 & 45.04 & 17.35 & 41.16 & 9.97 \\
$\mathbf{8}$ & 0.001 & 0.05 & 0.11 & 0.38 & 0.72 & 0.22 & N/A & N/A & N/A & N/A & N/A \\
\hline
\end{tabular}

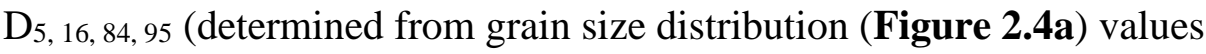
were used to calculate sorting, $\sigma$ (Table 2.2). Sediment D50 (CGS) values are negatively correlated with measured channel width $\left(\mathrm{R}^{2}=0.6674\right)$ (Figure $\left.2.4 \mathrm{c}\right)$ and water depth $\left(\mathrm{R}^{2}=0.821\right)$ at each site. 
The fine percent (\%Fine) refers to sediment $\leq 2 \mathrm{~mm}$, the finer percent (\%Finer) refers to the sediment $\leq 0.063 \mathrm{~mm}$ within the $\%$ Fine subsample. Our findings show that there is high variability with the silt-clay $(\leq 0.063 \mathrm{~mm})$ size fraction, both downstream and on the banks. The \%Fine in BGS samples are also variable but the \%Fine in CGS have an overall increase downstream, where sites $1 \mathrm{CH}-4 \mathrm{CA}$ are $<20 \%$ and downstream sites $5 \mathrm{SA}-7 \mathrm{~PB}$ are $>30 \%$ (Table 2.2).

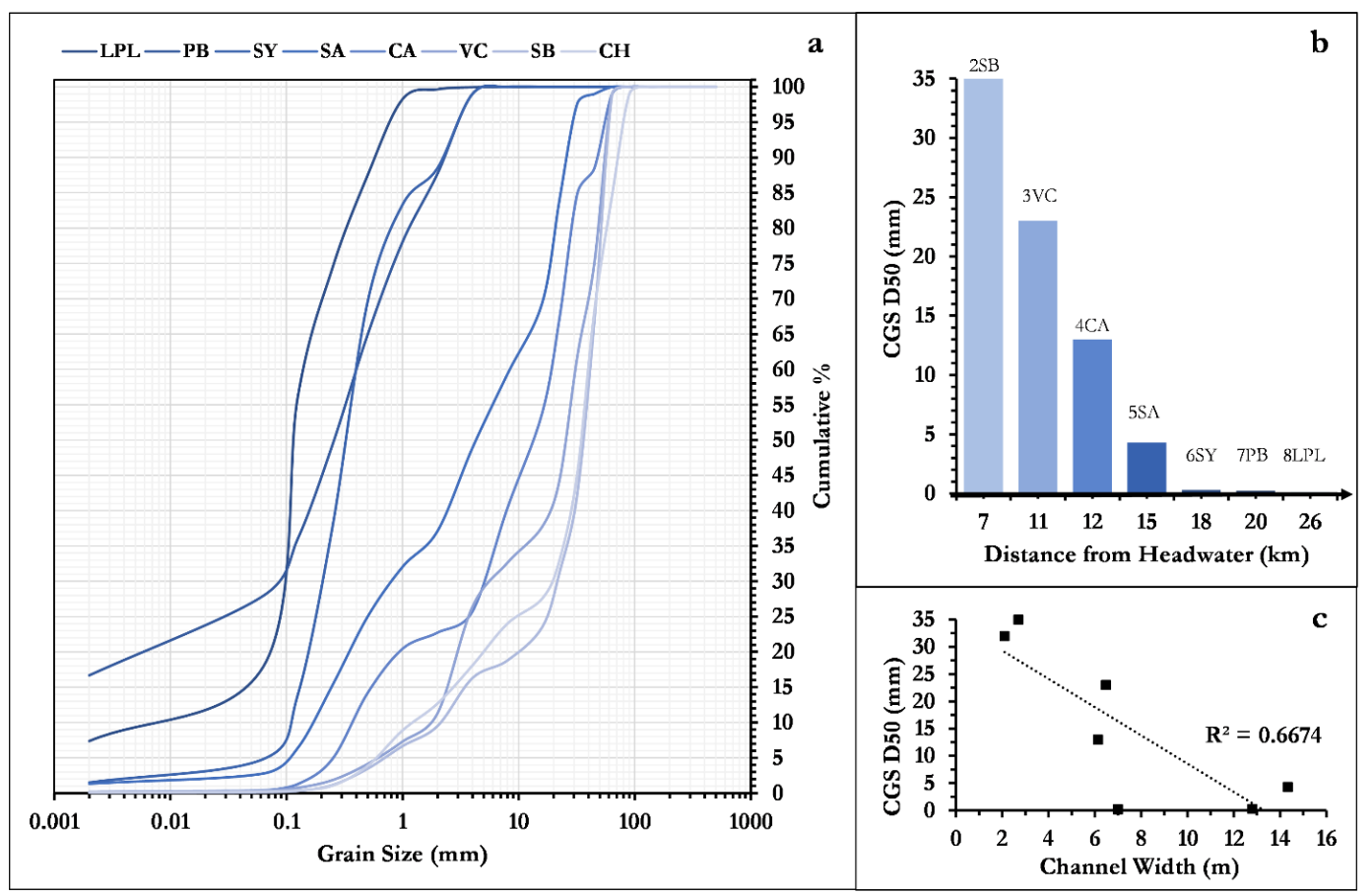

Figure 2.4 Grain size distribution for CGS (blue) downstream to upstream (a) CGS D50 values upstream to downstream (b) D50 correlation with channel width (c).

\subsubsection{Metals}

Of the bulk metals measured in the 80 grab samples, the concentrations of As, $\mathrm{Cu}$, and $\mathrm{Hg}$ exceed the Effects Range Low (ERL) (Table 2.3) at several of the sites. Whereas As concentrations accumulate downstream, $\mathrm{Cu}$ concentrations varied longitudinally but were highest in the tributary. Exceeding ERL at every site, $\mathrm{Hg}$ ranged from $3.8-4.6 \mathrm{ppm}$ in channel and reached $6 \mathrm{ppm}$ in the lagoon (Table 2.3). 
Table 2.3 Effects Range Low values compared against site concentrations (ppm).

\begin{tabular}{|l|l|l|l|l|l|l|l|}
\hline Site & As & Cd & Cr & Cu & Hg & Pb & Zn \\
\hline $\begin{array}{l}\text { SQuiRTs } \\
\text { ERL }\end{array}$ & 8.2 & 1.2 & 81 & 34 & 0.015 & 46.7 & 150 \\
\hline 1CH & 5.92 & <LOD & 53.17 & 90.38 & 4.45 & 12.94 & 84.37 \\
2SB & 3.95 & <LOD & 17.29 & 56.37 & 3.88 & 12.87 & 82.92 \\
3VC & 4.97 & <LOD & 22.14 & 60.90 & 3.85 & 14.50 & 71.44 \\
4CA & 6.28 & <LOD & 25.76 & 48.55 & 4.03 & 16.30 & 95.98 \\
5SA & 6.87 & <LOD & 22.95 & 37.36 & 4.16 & 16.63 & 77.80 \\
6SY & 4.82 & <LOD & 17.91 & 51.19 & 3.70 & 10.99 & 46.03 \\
7PB & 18.30 & <LOD & 24.51 & 66.84 & 4.58 & 19.51 & 90.98 \\
LPL & 12.66 & <LOD & 30.13 & 17.29 & 6.03 & 16.28 & 52.00 \\
\hline
\end{tabular}

There is a higher input of As coming from 1CH than 2SB (Table 2.3) and concentrations increase at 7PB. LPL values in (Table 2.3) is an average of the three lagoon sampling sites, however at the two sampling locations downstream of LPC in the lagoon, As increases until the mouth of the lagoon (Figure 2.5). Measures for Cd were less than the limit of detection (<LOD) and not of concern. $[\mathrm{Cr}],[\mathrm{Pb}]$ and $[\mathrm{Zn}]$ are below the ERL at all sites (Table 2.3). The metals of primary concern for sub watershed monitoring are $\mathrm{Cu}$ and $\mathrm{Hg}$ as $88 \%$ or $100 \%$ of all samples exceeded ERL values, 34 and 0.015 ppm, respectively. 


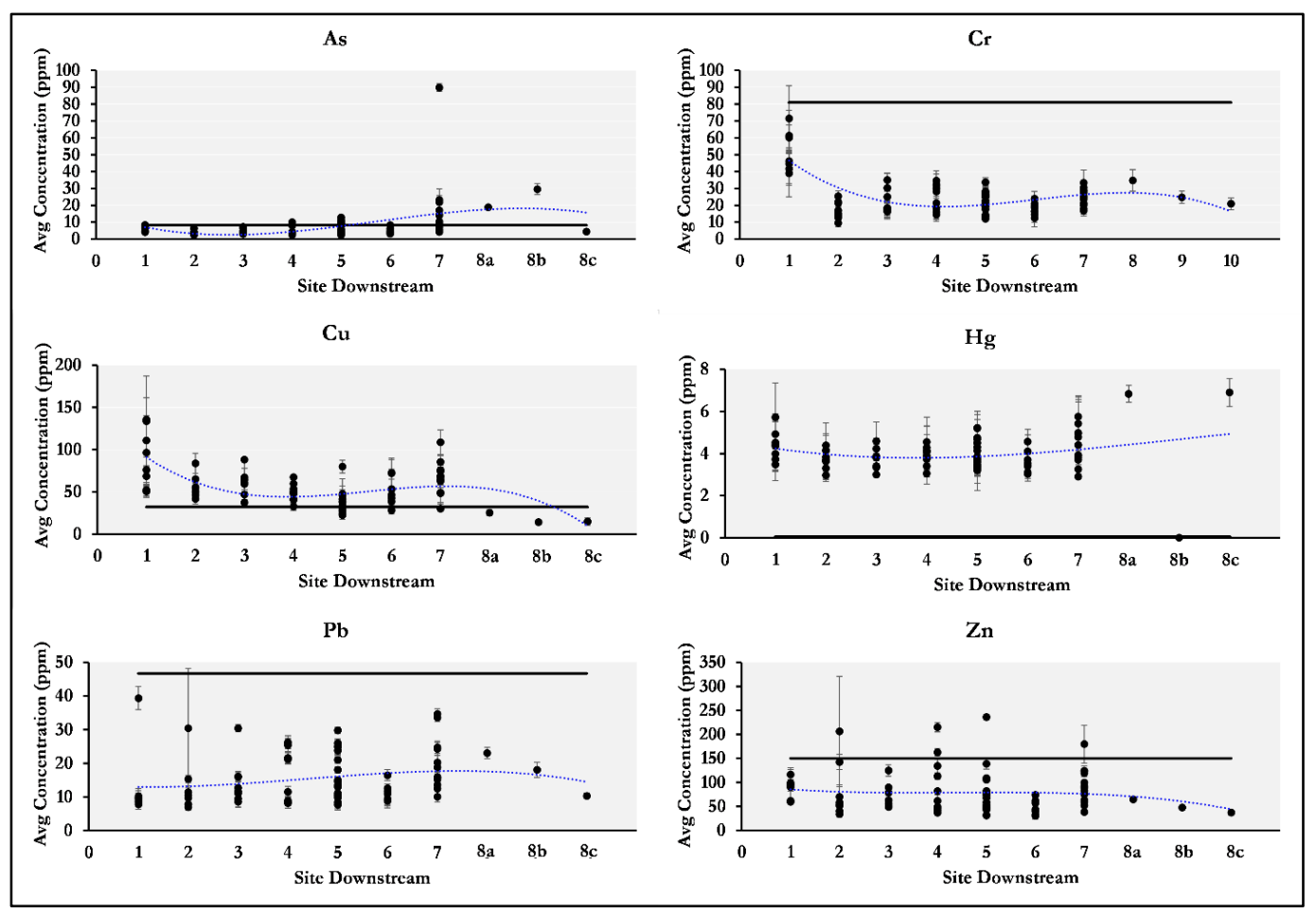

Figure 2.5 Downstream metal concentration for individual GS. LPL site 8-a, -b, $\mathrm{c}$ are individual downstream sampling locations in the lagoon.

Metal to metal analysis (Appendix E: Correlation Analysis) showed correlations ranging from 0.61-0.89 among $\mathrm{As}, \mathrm{Hg}, \mathrm{Pb}$, and $\mathrm{Zn}$ for both inchannel and on-bank samples, the highest correlations for both being between $\mathrm{Hg}$ and $\mathrm{Pb}$. For $\mathrm{Cr}$, the strongest correlations (>0.5) were with $\mathrm{Pb}(0.75), \mathrm{Hg}(0.68)$, and $\mathrm{Zn}(0.65)$. For $\mathrm{Cu}$, the strongest correlations were with $\mathrm{As}(0.69)$ and $\mathrm{Zn}$ (0.57). It should be noted that $\mathrm{As}, \mathrm{Hg}, \mathrm{Pb}$, and $\mathrm{Zn}$ all increase within reach for inchannel sediments, but they do not have the same pattern on the banks. When comparing the longitudinal pattern for each metal the pattern is inconsistent for in-channel versus on-banks (e.g. channel $\mathrm{Pb}$ increases within each reach, while bank $\mathrm{Pb}$ does not). In the middle reach (4CA, 5SA), all metal concentrations were higher on the banks, except for $\mathrm{Hg}$ which had low average concentrations (Figure 2.6). 


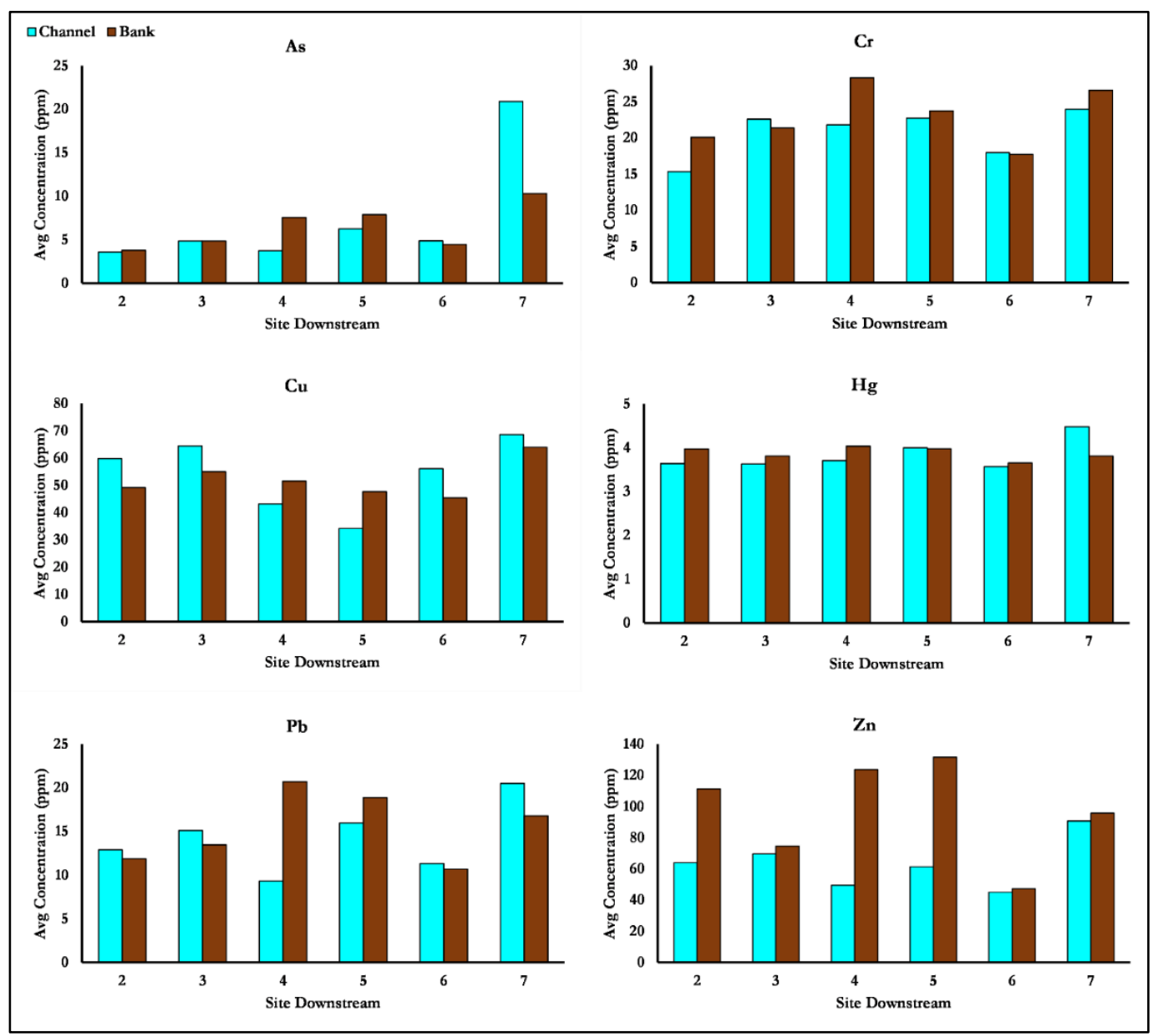

Figure 2.6 Average metal concentration for sites going downstream (2SB, 3VC, 4CA, 5SA, 6SY, 7PB) separated by in-channel samples and bank samples.

\subsubsection{Organic Carbon}

Organic Carbon (\%OC) downstream varies in channel from $2-11 \%$ and varies from $3-13 \%$ on the banks at differing sites (Figure 2.7a-b). Percent CGS fine sediment ( $\leq 2 \mathrm{~mm}$ diameter and $<0.063 \mathrm{~mm}$ ) is positively related with $\% \mathrm{OC}$ $\left(\mathrm{R}^{2}=0.14, \mathrm{p}<0.05\right.$ and $\mathrm{R}^{2}=0.28, \mathrm{p}<0.01$, respectively). Regression analyses for both CGS and BGS show that $\mathrm{Zn}$ and $\mathrm{Pb}$ are most driven by \%OC (Figure 2.7c-f) followed by As and CGS Hg (Table 2.4). 
Table 2.4 95\% UCL for $\mathrm{As}, \mathrm{Cr}, \mathrm{Cu}, \mathrm{Hg}, \mathrm{Pb}, \mathrm{Zn}$ and OLS regression analysis with $\% \mathrm{OC}$ and $\%$ Fine ( $\leq 2 \mathrm{~mm}$ diameter). Significant values are bolded.

\begin{tabular}{|c|c|c|c|c|c|c|c|}
\hline Metal & Sample & UCL Test & $\begin{array}{l}95 \% \\
\text { UCL } \\
\text { (ppm) }\end{array}$ & $\%$ OC R & p-value & \%Fine R & p-value \\
\hline \multirow[t]{2}{*}{ As } & CGS & $\begin{array}{l}\text { KM (Chebyshev) } \\
\text { UCL }\end{array}$ & 12.02 & 0.40 & $<0.001$ & 0.07 & 0.09 \\
\hline & BGS & KM H-UCL & 7.11 & 0.35 & $<0.001$ & 0.07 & 0.18 \\
\hline \multirow{2}{*}{$\mathrm{Cr}$} & CGS & Modified-t UCL & 25.31 & 0.05 & 0.14 & 0.01 & 0.63 \\
\hline & BGS & Modified-t UCL & 30.02 & 0.01 & 0.67 & 0.23 & 0.01 \\
\hline \multirow[b]{2}{*}{$\mathrm{Cu}$} & CGS & Modified-t UCL & 59.10 & 0.10 & $<0.05$ & 0.06 & 0.11 \\
\hline & BGS & $\begin{array}{l}\text { Approximate } \\
\text { Gamma UCL }\end{array}$ & 60.12 & 0.01 & 0.57 & 0.45 & $<0.0001$ \\
\hline \multirow[b]{2}{*}{ Hg } & CGS & KM H-UCL & 3.48 & 0.44 & $<0.001$ & 0.11 & 0.03 \\
\hline & BGS & $\begin{array}{l}\text { GROS } \\
\text { Approximate } \\
\text { Gamma UCL }\end{array}$ & 3.65 & 0.06 & 0.23 & 0.21 & 0.01 \\
\hline \multirow{2}{*}{$\mathbf{P b}$} & CGS & Modified-t UCL & 15.92 & 0.58 & $<0.001$ & 0.16 & 0.01 \\
\hline & BGS & Modified-t UCL & 16.82 & 0.35 & $<0.001$ & 0.21 & 0.01 \\
\hline \multirow{2}{*}{ Zn } & CGS & Modified-t UCL & 71.61 & 0.74 & $<0.001$ & 0.03 & 0.25 \\
\hline & BGS & H-UCL & 105.50 & 0.77 & $<0.001$ & 0.07 & 0.18 \\
\hline
\end{tabular}

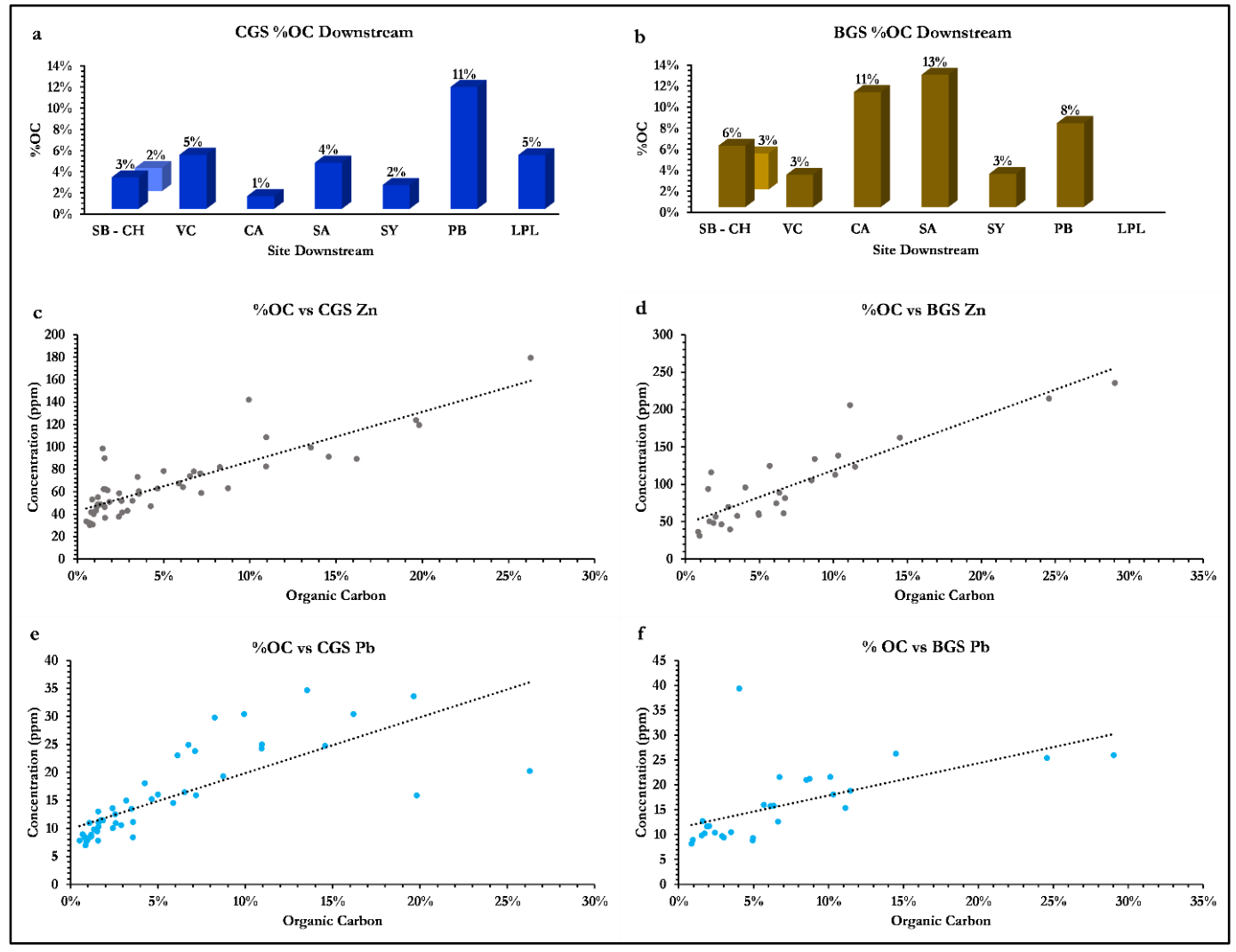

Figure 2.7 \%OC distribution upstream to downstream for CGS (a) and BGS (b), $\% \mathrm{OC}$ correlation with CGS [Zn] (c) BGS [Zn] (d), CGS [Pb] (e), and BGS [Pb] (f). 


\subsubsection{Phosphate}

Orthophosphate screening showed that $\mathrm{PO}_{4}{ }^{3-}$ concentrations were as follows: SA $5>$ VC $3>$ SY $6>$ SB 2. Depth (D), pressure (P), temperature (T), and $\mathrm{PO}_{4}{ }^{3-}$ concentrations increase within the upper, middle, and lower reaches (Figure 2.8a). Dissolved oxygen (DO) and $\mathrm{pH}$ (7.74-8.24) increase in the upstream reach and decrease in the middle and lower reaches (Figure 2.8b). Salinity (SAL) closely resembles the DO and $\mathrm{pH}$ pattern.

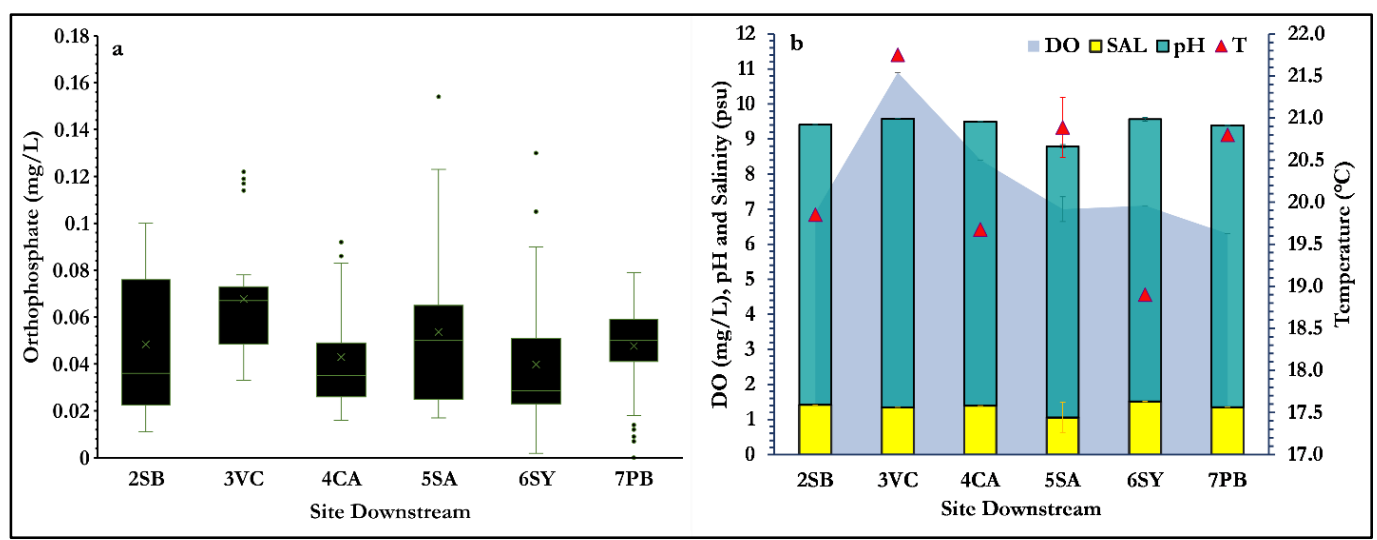

Figure 2.8 Downstream phosphate (a) and water quality parameters (dissolved oxygen, DO; salinity, SAL; pH, and temperature, T) (b). Screening levels for phosphate are on average for each site are below $0.1 \mathrm{mg} / \mathrm{L}$ but several samples are near or exceed screening limit specifically at 2SB, 3VC, 5SA, and 6SY (a). Quality variables at 5SA were taken at multiple channels along the floodplain.

\subsection{Discussion}

\subsubsection{Channel Morphology}

The reach-by-reach trends at Los Peñasquitos Creek reflect the variable geography of the canyon. While the overall slope gradually declines $(0.008$, reach means show a clear distinction where the upper and lower reaches have a reach slopes of 0.007 and 0.007 , separated by the middle reach with a slope that drops to 0.005 . The slopes broken into local site scale of $1 \mathrm{~km}(\sim 500 \mathrm{~m}$ upstream and downstream of the cross-section) at each cross section (XS) shows detailed 
variations (Table 2.1). Both the upper and middle reaches have an increase of localized slope, from 2SB-3VC and 4CA-5SA, while the lower reach has a decrease in slope, from sites 6SY-7PB (Table 2.1). Reach variability (Pietsch \& Nanson 2011) and slope variability are important in understanding some of the non-linear morphologic (W, D, V, Q) patterns (Lecce 1997).

While channel width traditionally increases downstream (Bierman \& Montgomery, 2020), the channel width follows an increase, increase, and decrease pattern within the three reaches, respectively. The middle reach part of the canyon widens and slope shallows resulting in multiple channels, especially at 5SA. The width and multiple channels may additionally be influenced by the lateral displacement of flow at 5SA and 6SY by vegetation within the flow path (Pietsch \& Nanson, 2011). At Los Peñasquitos Creek, individual site channels W and $\mathrm{Q}$ are similar (Figure 2.3), where the upper and middle reaches increase within the reach, and the lower reach values decrease. Interestingly, in Southeastern Australia, Pietsch \& Nanson (2011) found that W was most responsive to $\mathrm{Q}$, and $\mathrm{Q}$ decreased due to vegetation, which we found also occurs at site 7PB in this study. Vegetation may also be a control on channel width (through bank stabilization) and downstream discharge (through water uptake) (Pietsch \& Nanson, 2011). The geomorphic and dynamic local differences of each site influence Q. The large Q at $1 \mathrm{CH}$ reflects the correspondingly steep slope (0.019) and high velocity at the cut banks; $3 \mathrm{VC}$, near the confluence of Chicarita and $\mathrm{LPC}$, receives flow from the tributary $(1 \mathrm{CH})$ and surrounding storm drains; and 5SA maintained flow in 5 of 6 channels spread out across the site. Other 
potential causes for reduced discharge may be due to channel seepage, which is common in semi-arid regions (Marquart, Goldbach, \& Blaum, 2020).

Both D and V generally exhibit downstream trends (Figure 2.3) of decreasing velocity and increasing depth. The pooling nature at 7PB (likely caused by upstream and downstream vegetation) causes an increased depth. Similar or deeper depths are also seen in upstream site 4CA, and downstream site $1 \mathrm{CH}$, not due to vegetation, but rather caused by the riffle-pool effect. Riffles occur when there is an accumulation of coarser gravels, shallowing the water depth. This increases the roughness which decreases the velocity as the river flows over. However, the riffle area induces steepening and small jumps which thus induce irregular velocity, flows, and eddies. Pools on the contrary are often deeper, scoured areas of reduced roughness and have low-flow. In fact, during low-flow, sediment settles to the bottom of the channel. During high-flow events, the gravels from riffles may mobilize and be replaced, while pool velocity increases instigate scouring of the banks causing geomorphic changes, higher turbidity, and total suspended solids.

\subsubsection{Sediment}

Longitudinally, channel grain size decreases downstream and becomes well-sorted (Bierman \& Montgomery, 2020). BGS were finer than CGS overall (Figure 2.4), with nearly equal grain sizes at sites 5SA and 7PB. This likely reflects the geomorphic response to the widening channel at 5SA and the downstream eco-geomorphic deposition at 7PB. The topography of $1 \mathrm{CH}$ tributary and surrounding geographic features (such as stream input from two higher 
elevation mountains), are likely responsible for larger gravels moving into the channel and resulting in greater sediment heterogeneity (influenced by bank erosion, meander, and Q) than other sites. Channel grain size D50s (Table 2.2) were inversely correlated to channel depth $\left(\mathrm{R}^{2}=0.821\right)$. CGS D50s (Table 2.2) and widths (Table 2.1) are also inversely related $\left(\mathrm{R}^{2}=0.667\right)$ where small grain size corresponds to larger width. This supports the results of Rengers \& Wohl (2007) and Walther (2016) that channel width is a local control on grain size, and at Los Peñasquitos, downstream slope may be a control on the channel width.

\subsubsection{Metals}

Metal concentrations often increase downstream because they tend to be strongly correlated with fine sediment (Cesar, Egler, Polivanov, Castilhos, \& Rodrigues, 2011; Marasinghe Wadige et al., 2016; Phillips \& Slattery, 2007; Xun \& Xuegang, 2015), which typically increases in abundance with distance downstream (Marasinghe Wadige et al., 2016; Phillips \& Slattery, 2007). However, due to the spatial heterogeneity of fine grain size (diameter $\leq 2 \mathrm{~mm}$ and $\leq 0.063)$ throughout the channel, metal concentration did not increase downstream, but rather varied longitudinally and across the cross-sections (Figure 2.5). Even though grain size decreases downstream at LPC (Figure 2.4), metal concentrations do not exhibit an increase as might otherwise be expected. Metal adsorption on $\leq 0.063 \mathrm{~mm}$ is greater than adsorption on the $\leq 2 \mathrm{~mm}$ per correlation analysis (Appendix E) but the silt-clay fraction also varied downstream for both CGS and BGS. However, when looking independently at metal concentrations laterally at each cross section, we found increasing metal concentrations on banks 
and farther from the channel center, especially for $\mathrm{Zn}, \mathrm{Cu}$, and $\mathrm{Pb}$ at $4 \mathrm{CA}$ and 5SA. For channel vs bank samples, this study found that metals ( $\mathrm{As}, \mathrm{Cr}, \mathrm{Cu}, \mathrm{Pb}$, Zn) were higher on the banks of the two sites $(4 \& 5)$ in the middle reach (Figure 2.6). This is likely reflective of the canyon shape and flattening slope which influences the deposition patterns and widening channel.

Cadmium, chromium, lead, and zinc are not a high concern at Los Peñasquitos Creek. Since $[\mathrm{Cd}]$ are higher in the lagoon, the input may be coming from another source besides LPC. While [Cr] was below the LOD, monitoring at $1 \mathrm{CH}$ (the tributary) during drought years is recommended. Lead concentration $[\mathrm{Pb}]$ may also exceed ERL in drought years or dry season (Makinde et al., 2016) as well as $[\mathrm{Zn}]$. In order from highest to lowest correlation with \%OC, channel $[\mathrm{Zn}],[\mathrm{Hg}],[\mathrm{Pb}],[\mathrm{As}],[\mathrm{Cu}],[\mathrm{Cr}]$ and bank $[\mathrm{Zn}],[\mathrm{Pb}]$, and $[\mathrm{As}]$ exhibited strongest correlations (>0.5), with $\mathrm{Zn}, \mathrm{Hg}, \mathrm{Pb}$, and As being the focus for regression analysis. However, unlike $\mathrm{Hg}, \mathrm{Pb}$ and $\mathrm{As}, \mathrm{Zn}$ is an essential metal that is necessary for biological systems and is normally found in higher concentrations (Cesar et al., 2011; Wuana \& Okieimen, 2014). Increased decomposition from riparian vegetation paired with dry season could result in $\mathrm{Pb}, \mathrm{As}$, and $\mathrm{Zn}$ concentrations that exceed their ERL.

After a rainy season, it is possible that arsenic in water or sediment upstream was washed downstream and remained downstream (7PB, 8LPL-a, 8LPL-b), captured in riparian vegetation, where there is decreased flow, finer grain size, and increased organic matter. Closer to the lagoon mouth (8LPL-OR), [As] drops below the ERL, possibly due to mixing, uptake, or sorption of As 
(Wang, Lin, He, Liu, \& Liu, 2013; Zhang, Li, Zheng, Chen, \& Zheng, 2017). This could be of concern because the oyster reef at this site provides habitat for estuarine mobile fauna (refer to Appendix A). We recommend continued monitoring for As at 7PB and the south side of the lagoon.

Every sampling site (except 4CA), contained one sample where $\mathrm{Cu}$ had a larger error that was likely caused by sample heterogeneity. However, like the findings of Makinde et al., (2016) [Cu] was high at all sites, $88 \%$ percent of samples exceeded ERL (Figure 2.5) and should be monitored throughout the channel and tributary. Additionally $[\mathrm{Hg}]$ exceed ERL levels at all sampling sites (Figure 2.5) and should also be monitored regularly particularly because methylation of $\mathrm{Hg}$ poses a threat to local ecology (Cesar et al., 2011). Concentration in the lagoon may be low due to sampling or reading error at 8LPL-b (Figure 2.5) or uptake and binding of $\mathrm{Hg}$ by estuarine sediments or plants (Smith \& Schafer, 1999). The high concentration at 8LPL-c (Figure 2.5) could be coming from one of the other tributaries (Lopez Canyon Creek, Carmel Creek, or Carroll Canyon Creek) or be a result of accumulation in LPC.

During low flow conditions, only surface sediments are likely to mobilize, if at all, so that sub-surface sediment remains in place with little chance of scouring. Furthermore, the added decomposition of leafy-debris, may help create an organic-rich and low $\mathrm{pH}$ environment allowing metals to adsorb more readily. While the results for metals in CGS and BGS were not concerning, metal concentrations in the organic-rich sub-surface were not analyzed. For those metals that exceeded ERL's from our screening, further analysis on the sub-surface 
sediment, leachability, mobility, and bioavailability is recommended to identify any potential risks.

\subsubsection{Organic Carbon}

Organic Carbon (\%OC) CGS and BGS do not exhibit any overall downstream patterns, but CGSs increase within each reach and BGSs decrease in the upper reach but increase in the middle and lower reaches (Figure 2.7). Organic matter and \%OC seem to reflect qualitative observations of the riparian zone (Appendix A), where higher \%OC values occur where the density of vegetation is greatest, but this has not been tested. The \%OC may also have an impact on suspended sediment and turbidity, particularly at site 1, due to high water $\mathrm{V}$ and $\mathrm{Q}$ and right bank scouring, and at site 7 from in-channel vegetation (Lee, 2019). BGS \%OC was consistently greater than CGS \%OC at all sites except 3VC (confluence) and 7PB (farthest downstream in the canyon) for the same reasons as above. This reflects the eco-geomorphic interactions of the site where channel-vegetation can contribute to more accretion and therefore promote more vegetation growth (Corenblit \& Vautier, 2020; Stromberg et al., 2007). This also could be a contributing factor to decreased Q at the cross section surveyed since water can become impounded behind the vegetation and sediment beds (Pietsch \& Nanson, 2011), as well as taken up by the vegetation (Martinez \& Mcdowell, 2016; Martinez, Walther, Kusler, Greenfield, \& Kannarr, 2020). Besides greater volumes of deposition, the presence of vegetation contributes to higher \%OC and fine grain (Doran, 2016; Steiger \& Gurnell, 2002) on banks (Pietsch \& Nanson, 2011). 
Though total $\mathrm{Cu}$ and $\mathrm{Hg}$ concentrations all increase, decrease, and then increase between the reaches, similar to \%OC, they are not as strongly related as $\mathrm{Zn}, \mathrm{Pb}$, and $\mathrm{As}$ (Table 2.4). The correlations between bank and in-channel $\mathrm{Zn}, \mathrm{Pb}$, and $\mathrm{As}(\mathrm{Zn}: \mathrm{Pb}, 0.61,0.68 ; \mathrm{As}: \mathrm{Pb}, 0.65,0.62$; As:Zn, 0.52, 0.58) may also suggest similar properties allowing for binding to organic matter. Marasinghe Wadige et al. (2016) found that $[\mathrm{Zn}]>[\mathrm{Pb}]>[\mathrm{Cu}]$ when compared with fine silts and clays in fluvial beds. Furthermore, there is a linkage between silts, clays, and \%OC as confirmed by results in Table 2.4. The fine-sized particles paired with the lighter weight of organic matter is a reason for increased seasonal turbidity and suspended load (Lee, 2019). Not only is turbidity problematic for aquatic organisms, but the ability to suspend fine, organic-rich sediment can also help mobilize toxic metals downstream. For example, trace metals, specifically $\mathrm{Cu}$, $\mathrm{Hg}, \mathrm{Zn}$, and As, are known to form bonds with organic matter (Baptista-Salazar \& Biester, 2019) in the form of Iron (Fe) (Guénet et al., 2016) and Aluminum (Al) Oxides (Cesar et al., 2011). Cesar et al. (2011) states that low levels of bioavailable $\mathrm{Zn}$ and $\mathrm{Cu}$ could be justified by the lack of positive correlations between those concentrations and \%OC. Despite the low levels of \%OC content, Fe/Al-OM cluster and bioavailability analysis should be considered at LPC for $\mathrm{Zn}, \mathrm{Pb}, \mathrm{Hg}, \mathrm{As}$, and $\mathrm{Cu}$ since there were positive statistical relationships between [Metal] vs \%OC (Table 2.4) and stronger correlations between these metals as well (Appendix E). The upper, middle, and lower reach data for \%OC is likely influenced by the riparian zone (Ledesma et al., 2018) which should be mapped and quantitatively studied, as it may be changing, getting broader or denser due to 
changes in parameters such as warmer temperatures, heavier rainfall, and greater drainage from urbanization, than in the past.

\subsubsection{Phosphate}

Total phosphate and phosphorus readings are used to determine water quality by the potential for eutrophication. Levels between $0.025-0.1 \mathrm{mg} / \mathrm{L}$ may stimulate plant growth and above $0.1 \mathrm{mg} / \mathrm{L}$ can have consequences.

Orthophosphate monitoring results showed that $\left[\mathrm{PO}_{4}{ }^{3}\right]$ were as follows: $5 \mathrm{SA}>$ $3 \mathrm{VC}>6 \mathrm{SY}>2 \mathrm{SB}$ (Figure 2.8a). 5SA flows through the canyon in the flattest part of the canyon with a neighborhood less than a quarter mile from the right bank. The concentrations for phosphate were highest for the water samples closest to the right bank. $3 \mathrm{VC}$ (confluence) is also near a neighborhood, with several drains entering directly into the channel. Additionally, the riparian zone does not create a closed canopy over the channel as much as at other sites. This allows more sunlight and warmth into the channel and temperature follows a similar reach-by-reach increasing trend (Figure $\mathbf{2 . 8 b}$ ) possibly reflecting the observational vegetation abundance at each site. Algae, an indicator for nutrient pollution (Jarvie et al., 2006; Lee, 2019), is abundantly floating or blanketing rocks at this site throughout the year. The left bank of 2SB is also located adjacent to a neighborhood and the left channel water samples were near or at the screening limit. $6 \mathrm{SY}$ is the only site that is not near an urbanized setting and is therefore less influenced by neighboring irrigation or storm drain runoff. 6SY does however have a commonly used horse trail directly through the channel where fecal matter is frequently observed by the park ranger (G. Washington, 
personal communication, August 27, 2020) and during field work that likely contributes to the higher nutrient content. $4 \mathrm{CA}$ also contained a nearby horse trail and had the second highest \%OC. Fecal coliform was not tested at any site. Phosphate screening against the $0.1 \mathrm{mg} / \mathrm{L}$ regulatory threshold was done to determine which sites may be at risk for eutrophication or excess nutrient input. Qualitative evidence of potential eutrophication is seen from excessive algal growth (both brown and green, stuck on rocks and floating) at 3VC, 4CA, 5SA, and 6SY (refer to Appendix A: Site descriptions). These are also the sites that were close to or surpassed the critical concentration, $0.1 \mathrm{mg} / \mathrm{L}$ (Figure 2.8), for incipient eutrophication (Fadiran, Dlamini, \& Mavuso, 2008; Putz, 2008). While few samples exceed the $0.1 \mathrm{mg} / \mathrm{L}$ screening limit for orthophosphate, a southern California study by Domagalski \& Saleh (2015) found that the phosphorus loss was highest in small and intermediate-sized streams and additionally the local geology is one of three primary sources of phosphorus loads in stream concentrations in the region, the other sources being fertilizers and agricultural use. Phosphate averages increased within each reach like temperature and salinity.

\subsection{Conclusion}

Each sampling site at Los Peñasquitos Creek has unique features that control and cause these results and reach patterns. The reach-by-reach pattern for channel morphology is not unusual and has been documented previously by Pietsch \& Nanson (2011). Reach pattern at Los Peñasquitos Creek reflect the slope and watershed land distribution, where the upstream reach $(1 \mathrm{CH}, 2 \mathrm{SB}$, $3 \mathrm{VC}$ ) is influenced by development; the middle reach by the preserve functions 
and shallower slope; and the downstream reach by the semi-arid fluvial geomorphic patterns. Parameters that increase within reach are channel water depth, \%OC, temperature, and phosphate. Parameters that decrease within each reach are velocity, elevation, and salinity.

The unique features such as localized slope, geography, and vegetation can help explain why certain parameters had more downstream variability. Interestingly this included channel width which was most responsive to discharge and supports the results of Pietsch \& Nanson (2011). This finding can be useful for planning in the preserve, particularly with respect to flood management.

Generalizations derived from hydraulic geometry may not be applicable to all river systems (Lecce, 1997). Considering their dynamic nature and sensitivity to spatial and temporal changes, it is necessary to conduct a broad local survey to better assist watershed management to effectively focus their monitoring efforts. This study is an example of that, and this data can help focus future efforts and funding.

Though metal concentrations were variable downstream, we recommend dry season monitoring for: [As] at 7PB (Wagon Wheel Crossing) and the south side of the lagoon, $[\mathrm{Cr}]$ at Chicarita Creek, $[\mathrm{Cu}]$ and $[\mathrm{Hg}]$ throughout the channel and $\mathrm{Hg}$ also in Los Peñasquitos Lagoon due to methyl-mercuration risk to biota. Monitoring for $[\mathrm{Pb}]$ could be useful during a drought period within the channel but not necessary for LPL and [Zn] monitoring is not necessary since it is in low concentrations throughout the sub watershed and is an essential metal. The confluence, $3 \mathrm{VC}$ should be monitored for nutrient input. In addition to the 
suggested monitoring, future studies could include monitoring ions, quantifying bottom sediment metal contamination, and modeling flood scenarios and impacts, specifically flood impacts at 4CA (Ranch House Crossing) and 5SA (Carson's Crossing) for floodplain (banks and ephemeral pools) $\mathrm{Zn}, \mathrm{Cu}$, and $\mathrm{Pb}$ concentrations.

The importance of localized geomorphology-geochemistry studies is especially relevant for semi-arid coastal watersheds that are small in area but in high demand for urban growth (Hogan, 2002). Coastal counties in the United States are developing at twice the rate of inland counties (Conway, 2005) causing these watersheds to exceed their supporting capacity (Miguez et al., 2019) leading coastal zones to be more susceptible to environmental problems (Conway, 2005). Los Peñasquitos Creek, San Diego, California flows from urban land through sandstone canyons into dense vegetation and finally an estuary before it reaches the Pacific Ocean all within only 10 miles. The function of this watershed, like many coastal watersheds, is to provide open spaces, recreation, habitat, and nutrient transport. These ecosystem services are put to risk by anthropogenic and climatic changes, through increased urban runoff and cyclic storm-drought periods. Addressing future response to environmental impacts in coastal regions requires an understanding of the local factors related to the current patterns of geography and future plans for development (Conway, 2005). While each hydrologic basin is unique and dynamic, considering the lack of research in identifying fluvial-geochemical trends in smaller, urban, low-flow environments, this study can be used as an example for watersheds in similar environments. 


\subsection{Acknowledgements}

This work was supported by a USD Faculty Research Grant 2019 to S.

Walther and a graduate student award to R. Khalsa-Basra to present at AGU

2020. The authors wish to thank all field work crew: Preston Muñoz, Timothy

Layton, Grace Cawley, Abigail Bierzychudek, and Ekjot Basra. We also wish to thank San Diego City Parks and Recreation Department for permitting, specifically Ranger Gina Washington for site access, knowledge and support for the study done at Los Peñasquitos Creek. 


\section{$2.8 \quad$ References}

Ames, H. (2018). Factors Affecting a River's Velocity. Retrieved from https://sciencing.com/factors-affecting-rivers-velocity-8223150.html

Balunger, D. G., \& Mckee, G. D. (2009). Chemical Characterization of Bottom Sediments. Bottom Sediment, 43(2), 216-227.

Baptista-Salazar, \& Biester, H. (2019). The Role of Hydrological Conditions for Riverine Hg Species Transport in the Idrija Mining Area. Environmental Pollution, 247, 716-724. https://doi.org/10.1016/j.envpol.2019.01.109

Bierman, P. R., \& Montgomery, D. R. (2020). Drainage Basins. In Key Concepts in Geomorphology (2nd ed., pp. 239-270). New York: MacMillan Learning.

Birtwell, I. K. (1999). The Effects of Sediment on Fish and their Habitat. Retrieved from http://www.dfo-mpo.gc.ca/Library/240698.pdf

Blott, S. J., \& Pye, K. (2001). GRADISTAT: A Grain Size Distribution and Statistics Package for the Analysis of Unconsolidated Sediments. Earth Surface Processes and Landforms, 1248, 1241. https://doi.org/10.1002/esp.261

Bridge, J. S. (2003). Rivers and Floodplains: Forms, Processes, and Sedimentary Record. Binghampton: Blackwell Science Ltd. Retrieved from https://books.google.com/books?hl=en\&lr=\&id=_mdQhM84V_EC\&oi=fnd $\& p g=$ PR5\&dq=purpose+of+studying+rivers\&ots=FaEB8ihmSv\&sig=WOEg CU_XHnWzs-1Lh5i2XBLbOmw\#v=onepage\&q\&f=false

Brooks, R., \& Moore, J. (1989). Sediment-Water Interactions in the MetalContaminated Floodplain of the Clark Fork River, Montana, USA. GeoJournal, 19(1), 27-36.

Bunte, K., \& Abt, S. R. (2001). Sampling Surface and Subsurface Particle-Size Distributions in Wadable Gravel- and Cobble-Bed Streams for Analyses in Sediment Transport, Hydraulics, and Streambed Monitoring. USDA General Technical Report, 74(RMRS-GTR-74), 450. https://doi.org/10.1017/CBO9781107415324.004

California Department of Transportation. (2009). Los Peñasquitos Creek Location Hydraulic Study. Retrieved from https://www.keepsandiegomoving.com/Documents/NCC_doc/EIR/Supportin g/3.09_Hydrology/Los_Peñasquitos_Creek_Location-Hydraulidc-StdyMar09.pdf

California Regional Water Quality Board. (2011). Hydrology and Water Quality. San Diego. Retrieved from https://www.waterboards.ca.gov/sandiego/

Castro-Larragoitia, J., Kramar, U., Monroy-Fernández, M. G., Viera-Décida, F., \& García-González, E. G. (2013). Heavy Metal and Arsenic Dispersion in a Copper-Skarn Mining District in a Mexican Semi-Arid Environment: Sources, Pathways and Fate. Environmental Earth Sciences, 69(6), 19151929. https://doi.org/10.1007/s12665-012-2024-1

Cesar, R., Egler, S., Polivanov, H., Castilhos, Z., \& Rodrigues, A. P. (2011). Mercury, Copper and Zinc Contamination in Soils and Fluvial Sediments From an Abandoned Gold Mining Area in Southern Minas Gerais State, 
Brazil. Environmental Earth Sciences, 64(1), 211-222.

https://doi.org/10.1007/s12665-010-0840-8

Conway, T. M. (2005). Current and Future Patterns of Land-Use Change in the Coastal Zone of New Jersey. Environment and Planning B: Planning and Design, 32, 877-893. https://doi.org/10.1068/b31170

Corenblit, D., \& Vautier, F. (2020). Formation and dynamics of vegetated fluvial landforms follow the biogeomorphological succession model in a channelized river. Earth Surface Processes and Landforms, 2035(April), 2020-2035. https://doi.org/10.1002/esp.4863

Domagalski, J., \& Saleh, D. (2015). Sources and Transport of Phosphorus to Rivers in California and Adjacent States, U.S., as Determined by Sparrow Modeling 1. Journal of the American Water Resources Association, 51(6), 1463-1486. https://doi.org/10.1111/1752-1688.12326

Doran, C. (2016). Land Use and Its Relationship to Riparian Zone Organic Carbon Storage on the Upper Hunter River. University of Wollongong.

Du, J., Qian, L., Rui, H., Zuo, T., Zheng, D., Xu, Y., \& Xu, C. Y. (2012). Assessing the Effects of Urbanization on Annual Runoff and Flood Events Using an Integrated Hydrological Modeling System for Qinhuai River Basin, China. Journal of Hydrology, 464-465, 127-139. https://doi.org/10.1016/j.jhydrol.2012.06.057

Ejarque, E., Freixa, A., Vazquez, E., Guarch, A., Amal, S., Fazi, S., ... Butturini, A. (2017). Science of the Total Environment Quality and Reactivity of Dissolved Organic Matter in a Mediterranean River Across Hydrological and Spatial Gradients. Science of the Total Environment, 600, 1802-1812. https://doi.org/10.1016/j.scitotenv.2017.05.113

Fadiran, A. O., Dlamini, S. C., \& Mavuso, A. (2008). A Compative Study of the Phosphate Levels in Some Surface and Ground Water Bodies of Swaziland. Chemical Society of Ethiopia, 22(2), 197-206.

Fletcher, T. D., Andrieu, H., \& Hamel, P. (2013). Understanding, Management and Modelling of Urban Hydrology and Its Consequences for Receiving Waters: A State of the Art. Advances in Water Resources, 51, 261-279. https://doi.org/10.1016/j.advwatres.2012.09.001

Folk, R. L., \& Ward, W. C. (1957). Brazos River bar [Texas]; a Study in the Significance of Grain Size Parameters. Journal of Sedimentary Research, 27(1), 3-26. Retrieved from https://pubs.geoscienceworld.org/sepm/jsedres/articleabstract/27/1/3/95232/Brazos-River-bar-Texas-a-study-in-thesignificance?redirectedFrom $=$ fulltext

Gober, P. (2010). Desert urbanization and the challenges of water sustainability. Current Opinion in Environmental Sustainability, 2(3), 144-150. https://doi.org/10.1016/j.cosust.2010.06.006

Greer, K., \& Stow, D. (2003). Vegetation Type Conversion in Los PEñasquitos Lagoon, California: An Examination of the Role of Watershed Urbanization. Environmental Management, 31(4), 489-503. https://doi.org/10.1007/s00267-002-2849-6

Guénet, H., Davranche, M., Vantelon, D., Pédrot, M., Al-sid-cheikh, M., Dia, A., 
\& Jestin, J. (2016). Evidence of Organic Matter Control on as Oxidation by Iron Oxides in Riparian Wetlands. Chemical Geology, 439, 161-172. https://doi.org/10.1016/j.chemgeo.2016.06.023

Hawley, R J, \& Bledsoe, B. P. (2013). Channel enlargement in semiarid suburbanizing watersheds: A southern California case study. Journal of Hydrology, 496, 17-30. https://doi.org/10.1016/j.jhydrol.2013.05.010

Hawley, Robert J, \& Bledsoe, B. P. (2011). How Do Flow Peaks and Durations Change in Suburbanizing Semi-Arid Watersheds? a Southern California Case Study. Journal of Hydrology, 405(1-2), 69-82. https://doi.org/10.1016/j.jhydrol.2011.05.011

Hogan, R. (2002). The Failure of Planning: Permitting Sprawl in San Diego Suburbs, 1970-1999.

Hoogsteen, M. J. J. Lantinga, E. A. Bakker, E. J. Groot, J. C. J. Tittonell, P. A. (2015). Estimating Soil Organic Carbon Through Loss on Ignition: Effects of Ignition Conditions and Structural Water Loss. European Journal of Soil Science, 66, 320-328. https://doi.org/10.1111/ejss.12224

Jarvie, H. P., Neal, C., \& Withers, P. J. A. (2006). Sewage-Effluent Phosphorus: A Greater Risk to River Eutrophication Than Agricultural Phosphorus? Science of the Total Environment, 360, 246-253. https://doi.org/10.1016/j.scitotenv.2005.08.038

Jodar-Abellan, A., Valdes-Abellan, J., Pla, C., \& Gomariz-Castillo, F. (2019). Science of the Total Environment Impact of Land Use Changes on Flash Flood Prediction Using a Sub-Daily SWAT Model in Five Mediterranean Ungauged Watersheds (SE Spain). Science of the Total Environment, 657, 1578-1591. https://doi.org/10.1016/j.scitotenv.2018.12.034

Lecce, S. A. (1997). Nonlinear Downstream Changes in Stream Power on Wisconsin's Blue River. Association of American Geographers, 87(3), 471486.

Ledesma, J. L. ., Kothawala, D. N., Bastviken, P., Maehder, S., Grabs, T., \& Futter, M. N. (2018). Stream Dissolved Organic Matter Composition Reflects the Riparian Zone , Not Upslope Soils in Boreal Forest Headwaters Water Resources Research. American Geophycial Union, 3896-3912. https://doi.org/10.1029/2017WR021793

Lee, B. J. (2019). Seasonal Dynamics of Organic Matter Composition and Its Effects on Suspended Sediment Flocculation in River Water Water Resources Research. American Geophycial Union, 6968-6985. https://doi.org/10.1029/2018WR024486

Leopold, L. B., \& Maddock, T. (1953). The Hydraulic Geometry of Stream Channels and Some Physiographic Implications. Geological Survey. Washington, D.C. Retrieved from https://pubs.usgs.gov/pp/0252/report.pdf

M.W. Steele Group, Rick Planning Group, \& Stepner, M. (2006). Black Mountain Ranch Subarea Plan: A Plan for Subarea I of the North City Future Urbanizing Area.

Makinde, O. W., Oluyemi, E. A., Tunbosun, I. A., Olabanji, I. O., Ogundele, K. T., \& Fakoya, O. T. (2016). Heavy Metal Contamination in Stream Water and Sediments of Gold Mining Areas of South Western Nigeria. African 
Journal of Environmental Science and Technology, 10(5), 150-161. https://doi.org/10.5897/ajest2015.2015

Marasinghe Wadige, C. P. M., Taylor, A. M., Krikowa, F., \& Maher, W. A. (2016). Sediment Metal Concentration Survey Along the Mine-Affected Molonglo River, NSW, Australia. Archives of Environmental Contamination and Toxicology, 70(3), 572-582. https://doi.org/10.1007/s00244-015-0259-z

Marquart, A., Goldbach, L., \& Blaum, N. (2020). Soil-Texture Affects the Influence of Termite Macropores on Soil Water Infiltration in a Semi-Arid Savanna. Ecohydrology, 13(August), 1-11. https://doi.org/10.1002/eco.2249

Martinez, A. E., \& Mcdowell, P. F. (2016). Invasive Reed Canarygrass ( Phalaris arundinacea ) and Native Vegetation Channel Roughness. Invasive Plant Science and Management, 9, 12-21. https://doi.org/10.1614/IPSM-D-1500046.1

Martinez, A. E., Walther, S. C., Kusler, J. E., Greenfield, B. K., \& Kannarr, S. (2020). Landscape Change and Vegetation-Channel Interactions in an Estuarine System. Journal of Coastal Conservation, 24(2).

Miguez, M. G., Verol, A. P., Battemarco, B. P., Yamamoto, L. M. T., Almeida de Brito, F., Fernandez, F. F., ... Rego, A. Q. (2019). A Framework to Support the Urbanization Process on Lowland Coastal Areas: Exploring the Case of Vargem Grande E Rio de Janeiro, Brazil. Journal of Cleaner Production, 231, 1281-1293. https://doi.org/10.1016/j.jclepro.2019.05.187

Miller, J. D., Kim, H., Kjeldsen, T. R., Packman, J., Grebby, S., \& Dearden, R. (2014). Assessing the Impact of Urbanization on Storm Runoff in a PeriUrban Catchment Using Historical Change in Impervious Cover. Journal of Hydrology, 515, 59-70. https://doi.org/10.1016/j.jhydrol.2014.04.011

Neeson, T., Gorman, A., Whiting, P., \& Koonce, J. (2008). Factors Affecting Accuracy of Stream Channel Slope Estimates Derived from Geographical Information Systems. North American Journal of Fisheries Management, 28, 722-732. https://doi.org/10.1577/M05-127.1

Phillips, J. D., \& Slattery, M. C. (2007). Downstream Trends in Discharge, Slope, and Stream Power in a Lower Coastal Plain River, 290-303.

https://doi.org/10.1016/j.jhydrol.2006.10.018

Pietsch, T. J., \& Nanson, G. C. (2011). Geomorphology Bankfull Hydraulic Geometry; The Role of In-Channel Vegetation and Downstream Declining Discharges in the Anabranching and Distributary Channels of the Gwydir Distributive Fluvial System, Southeastern Australia. Geomorphology, 129(12), 152-165. https://doi.org/10.1016/j.geomorph.2011.01.021

Putz, P. (2008). Elimination and Determination of Phosphates.

Rengers, F., \& Wohl, E. (2007). Trends of Grain Sizes on Gravel Bars in the Rio Chagres, Panama. Geomorphology, 83, 282-293.

https://doi.org/10.1016/j.geomorph.2006.02.019

Reza, A., Islam, H. M. T., Mia, U., Khan, R., \& Habib, A. (2020). Quantifying Source Apportionment, Co - occurrence, and Ecotoxicological Risk of Metals from Upstream , Lower Midstream , and Downstream River Segments , Bangladesh. Environmental Toxicology and Chemistry, 39(10), 2041-2054. https://doi.org/10.1002/etc.4814 
San Diego Coastkeeper. (2010). Los Peñasquitos Watershed. Retrieved from https:/www.sdcoastkeeper.org/learn/swimmable/san-diego-waterquality/san-diego-watersheds/los-penasquitos-watershed

Schertzinger, G., Ruchter, N., \& Sures, B. (2018). Metal Accumulation in Sediments and Amphipods Downstream of Combined Sewer Over Flows. Science of the Total Environment, 616-617, 1199-1207. https://doi.org/10.1016/j.scitotenv.2017.10.199

Smith, B. F., \& Kraft, J. R. (2013). A Cultural Resources Study for the Los Peñasquitos Adobe Drainage Project, San Diego County, California (CSD04.03). San Diego. Retrieved from https://www.sandiegocounty.gov/reusable_components/images/dgs/Documen ts/CEQA_LPAdobeExhibitB.pdf

Smith, J. N., \& Schafer, C. T. (1999). Sedimentation , Bioturbation , and Hg Uptake in the Sediments of the Estuary and Gulf of St . Lawrence. Limnology and Oceanography, 44(1), 207-219.

Steiger, J., \& Gurnell, A. M. (2002). Spatial Hydrogeomorphological Influences on Sediment and Nutrient Deposition in Riparian Zones: Observations From the Garonne River, France. Geomorphology, 49, 1-23.

Stein, E. D., Mazor, R. D., Mccune, K., Bledsoe, B. P., \& Adams, S. (2017). Application of Regional Flow - Ecology Relationships to Inform Watershed Management Decisions: Application of the ELOHA Framework in the San Diego River Watershed, California, USA. Ecohydrology, (January), 1-16. https://doi.org/10.1002/eco.1869

Stromberg, J. C., Beauchamp, V. B., Dixon, M. D., Lite, S. J., Paradzick, C., Services, E., \& Project, S. R. (2007). Importance of Low-Flow and HighFlow Characteristics to Restoration of Riparian Vegetation Along Rivers in Arid South-Western United States. Freshwater Biology, 52, 651-679. https://doi.org/10.1111/j.1365-2427.2006.01713.x

Sutherland, R. A. (1998). Loss-on-Ignition Estimates of Organic Matter and Relationships to Organic Carbon in Fluvial Bed Sediments. Hydrobiologia, 389, 153-167.

Tappin, A. D., Comber, S., \& Worsfold, P. J. (2016). Environmental Science Processes \& Impacts Orthophosphate-P in the nutrient impacted River Taw and its catchment ( SW England ) between 1990. Environmental Science Processes \& Impacts, 690-705. https://doi.org/10.1039/c6em00213g

USEPA. (2017). Phosphorus, Reactive (Orthophosphate) (Vol. 10).

USEPA. (2020). ProUCL 5.1.002 Software. Retrieved July 5, 2020, from https://www.epa.gov/land-research/proucl-software

Voynova, Y. G., Brix, H., Petersen, W., Weigelt-krenz, S., \& Scharfe, M. (2017). Extreme Flood Impact on Estuarine and Coastal Biogeochemistry: The 2013 Elbe Flood. Biogeosciences, 14, 541-557. https://doi.org/10.5194/bg-14-5412017

Walther, S. C. (2016). Environmental Flow Development: Geomorphic Considerations from the McKenzie River, Oregon. Yearbook of the Association of Pacific Coast Geographers, 78, 94-119. https://doi.org/10.1353/pcg.2016.0007 
Wang, S., Lin, C., He, M., Liu, X., \& Liu, S. (2013). Arsenic Distribution and Adsorption Behavior in the Sediments of the Daliao River System in China. Water Environment Research, 85(8), 687-695. https://doi.org/10.2175/106143012X13560205144894

Weston Solutions Inc. (2009). Los Peñasquitos Lagoon TMDL - Watershed Phase I Sediment Source Identification Study Watershed Phase I Sediment Source Final Report. Retrieved from https://www.sandiego.gov/sites/default/files/lospensedimentstudy.pdf

White, M. D., \& Greer, K. A. (2006). The Effects of Watershed Urbanization on the Stream Hydrology and Riparian Vegetation of Los Peñasquitos Creek, California. Landscape and Urban Planning, 74(2), 125-138. https://doi.org/10.1016/j.landurbplan.2004.11.015

Wuana, R. A., \& Okieimen, F. E. (2014). Heavy Metals in Contaminated Soils: A Review of Sources, Chemistry, Risks, and Best Available Strategies for Remediation. Heavy Metal Contamination of Water and Soil: Analysis, Assessment, and Remediation Strategies, 2011, 1-20. https://doi.org/10.1201/b16566

Xun, Y., \& Xuegang, L. (2015). Heavy Metals in Sediment From Bei Shan River: Distribution, Relationship With Soil Characteristics and Multivariate Assessment of Contamination Sources. Bulletin of Environmental Contamination and Toxicology, 95(1), 56-60. https://doi.org/10.1007/s00128-015-1560-2

Zhang, Y., Li, S., Zheng, L., Chen, J., \& Zheng, Y. (2017). Applied Geochemistry Evaluation of Arsenic Sorption and Mobility in Stream Sediment and Hot Spring Deposit in Three Drainages of the Tibetan Plateau. Applied Geochemistry, 77, 89-101. https://doi.org/10.1016/j.apgeochem.2016.04.006 
CHAPTER 3: MAPPING FLOOD AT LOS PEÑASQUITOS CREEK, A SMALL, URBANIZED, COASTAL WATERSHED IN SOUTHERN

CALIFORNIA

\subsection{Abstract}

Coastal watersheds in semi-arid climates are influenced by hydrologic variation from sedimentation, urbanization, and climate change. Southern California watersheds are unique in their small spatial-scale and are vulnerable to flooding from increased frequencies and intensities of short-duration heavy rainfalls and cyclic drought-storm patterns in the semi-arid climate. Runoff is exacerbated with population growth and land-cover change. This study uses two methods to estimate and model runoff in future scenarios using HEC-RAS. The first method estimates recurrence intervals (RI) based on local PeakFQ data. Commonly used in hydraulic engineering and flood modeling, the RI method estimates flows as an average number of times a peak flow will occur over a return period (years). For Los Peñasquitos watershed, the estimated flows for the RI years shown are as follows: RI-5=2,899, RI-10=4,095, RI-25=5,675, RI$50=6,870$, RI-100 $=8,066$, RI-500 $=10,841 \mathrm{cfs}$. To address the impact on flow from precipitation and soil saturation, the second method uses a 5-day Antecedent Precipitation Index (API) and daily precipitation in a multiple regression empirical model to estimate runoff. Future projections for rainfall, based on climate models using Representative Concentration Pathways (RCP) are applied to observed data and interpolated to RCP 2.6, 4.5, 6.0, and 8.5 scenarios and resulted in 7,908-8,246 cfs within the next 50-100 years. We recommend using 
future projections for rainfall and land-use to better estimate flow and address projected trends.

KEYWORDS: Fluvial Geomorphology, Coastal Watershed, Hydrologic Modeling, HEC-RAS, Antecedent Precipitation Index

\subsection{Introduction}

Rivers and wetlands are directly and indirectly influenced by variation in hydrology and sedimentation, as well as contamination, urbanization, and climate change. Changes in discharge or freshwater alter morphology (Hawley \& Bledsoe, 2013; Kochel, Miller, \& Ritter, 1997) and modify watershed services such as riverine habitat stability (Greer \& Stow, 2003), water quality (Voynova, Brix, Petersen, Weigelt-krenz, \& Scharfe, 2017), and ecology (Stein, Mazor, Mccune, Bledsoe, \& Adams, 2017). Fluvial geomorphic responses in semi-arid, southern California climates are very sensitive to these hydrologic changes due to the predominantly sedimentary make-up of the topography (Walawender, 1999) and the dynamic nature of small streams (Hawley \& Bledsoe, 2013). In southern California, floods can especially have lasting impacts due to the semi-arid climate and these flows are often increased by anthropogenic runoff (Kochel et al., 1997). Since flooding is a spatial problem, it is crucial to evaluate which areas are at most risk both currently and in the future, as urbanization and climate rapidly change.

\subsubsection{Flood source and risk}

Sources of floods include heavy rain storm surges (Kulkarni, Eldho, Rao, \& Mohan, 2014) and overflowing rivers from broken dams (Nikolic, Kostic, \& Nikolic, 2018), snowmelt (Dettinger \& Diaz, 2002), urban drainage (Miller et al., 
2014), and lack of vegetation or extensive impervious surfaces (Voynova et al., 2017). Flood risk, based on the potential damage of what we value, can be reduced but not fully eliminated. One way to reduce flood risk is through management, such as zoning, building codes, flood insurance, non-structural measures, and structural measurements (FEMA, n.d.). Some of these approaches are used by cities and counties. However, the residual impacts, future risk, and risk by small streams are often less frequently addressed. The purpose of mapping the floodplain and identifying possible areas of risk of inundation is to provide information to watershed management to prepare for future flooding.

\subsubsection{Coastal impacts}

Flooding varies across geographic location. Regions experience flood frequencies, sources, and impacts different from each other and, therefore, planning, preparedness, and infrastructure also varies. For example, semi-arid and arid climates are more prone to flash floods with low rainfall (Stromberg et al., 2007) whereas tropical monsoon climates are less prone and can handle larger loads (Kulkarni et al., 2014).

One of the benefits of having estuaries in coastal regions is that they provide a natural role in flood risk management by trapping sediment, metals, organic matter, debris and nutrients from entering the ocean (Smith \& Schafer, 1999; Voynova et al., 2017). However, if flooding passes the main channel of a coastal river system, it could temporarily change coastal wetland dynamics with lasting effects from excess material loading (Voynova et al., 2017). There could potentially be mass die-off of organisms, especially if the flooding occurs when 
the mouth of an estuary is closed, often causing hypoxic conditions, excess sediment or organic matter loading, and/or extreme turbidity, etc. (California Regional Water Quality Board, 2011). If it does not occur when the mouth is closed, there could still be a die-off of benthic invertebrates, plants, and nesting birds. Estuary mouths close once a year and sediment could re-escape the estuary if there is enough eliminating low marsh environment. If flooding conditions are prolonged, and salinity drops then freshwater associated plants (such as cattails in southern California), could outcompete native plants, and negatively impact the local ecologic dynamic (Voynova et al., 2017).

\subsubsection{Anthropogenic impacts}

Population growth and urbanization is a major cause of hydrologic changes within a watershed (Trimble, 2003). Rising populations in surrounding towns require deforestation and land-cover change for metropolitan development, increased water use, and direct drainage pipelines (Smith \& Kraft, 2013) that can further impact the watershed. Rainfall on these new impermeable surfaces shortens lag time between precipitation events and peak discharge. The excess surface flow makes roads prone to flash flooding and increased erosion (Bierman \& Montgomery, 2020). Runoff is responsible for delivering material downstream but faster surface flow, in turn, carries woody debris and displaces sediments, nutrients, and chemicals (Smith \& Kraft, 2013).

\subsubsection{Representative Concentration Pathways and Flow Modeling} The Intergovernmental Panel on Climate Change (IPCC) provides emissions scenarios and assessments based on world population trends. Scenarios 
are provided through Representative Concentrations Pathways (RCP) which approximate radiative forcing through emissions by 2100 . The most used scenarios for radiative forcing are RCP 2.6, 4.5, 6, and $8.5 \mathrm{~W} / \mathrm{m}^{2}$. Under RCP 2.6, carbon dioxide $\left(\mathrm{CO}_{2}\right)$ radiative forcing peaks by 2050 and returns to $2.6 \mathrm{~W} / \mathrm{m}^{2}$ by 2100. RCP 4.5 and 6.0 are intermediate, stabilization scenarios that approximate $1.1^{\circ} \mathrm{C}-2.6^{\circ} \mathrm{C}\left(4.5 \mathrm{~W} / \mathrm{m}^{2}\right)$ and $1.4^{\circ} \mathrm{C}-3.1^{\circ} \mathrm{C}\left(6.0 \mathrm{~W} / \mathrm{m}^{2}\right)$ at the end of the $21^{\text {st }}$ century and constant concentrations after 2150. RCP 8.5 is the "business-as-usual" scenario that approximates $8.5 \mathrm{~W} / \mathrm{m}^{2}$ at the end of the $21^{\text {st }}$ century, constant emissions post 2250 , and increases the global temperature from $2.6^{\circ} \mathrm{C}-4.8^{\circ} \mathrm{C}$ (“IPCC, 2013: Summary for Policy Makers,” 2013). These datasets provide predictions for temperature and precipitation, and have been used in hydrologic modeling (Chatterjee, 2018; Sridhar, Billah, \& Hildreth, 2018).

Flow modeling can be used to quantify and estimate the rates and potential inundation of floods or peak flow events. Previously, hydrologic models have been used in finding solutions to problems such as determining geographic effectiveness of detention ponds (Kulkarni et al., 2014), reducing impacts from urban growth (Bekhira, Habi, \& Morsli, 2019; Trimble, 2003), as well as mitigating impacts to vegetation (Wang, Zhang, Greimann, \& Huang, 2018) and quantifying morphologic response (Hawley \& Bledsoe, 2013). Several studies also used flood modeling to determine multiple (benthic macro-invertebrate) species response to these hydrologic alterations (Mazor, Mccune, May, Bledsoe, $\&$ Stein, 2018) and to plan for future water resources with considerations of a changing climate (Meixner et al., 2016). 
Precipitation is an important variable for watershed management when estimating hydrologic changes under future climate or in response to fluctuation. However, methodologies are often complex and result in a minimum estimate with associated spatial variability considering the stochastic nature of freshwater systems (Vinodkumar et al., 2017). In the rational and empirical methods used to estimate runoff, assumptions must be made that limit or ignore many of the important influences to hydrology, such as soil moisture (Koster, Guo, Yang, Dirmeyer, \& Mitchell, 2009) and soil type (Vinodkumar et al., 2017), antecedent precipitation (Descroix, Nouvelot, \& Vauclin, 2002), and slope (Salvadore, Bronders, \& Batelaan, 2015). There are also many unknown future variables, such as development extent, riparian zone changes, storm frequency or duration, etc. Projecting forward is generally limited to assessing the effects of only one variable (Salvadore et al., 2015), such as future projections for climate (Chatterjee, 2018; Chen \& Kumar, 2001). The Antecedent Precipitation Index attempts to address issues associated with antecedent conditions and has been used to successfully estimate runoff from precipitation in arid (Descroix et al., 2002) and semi-arid (Nikas, Antonakos, Lambrakis, \& Kallergis, 2007) climates. This method takes soil saturation into account by weighting the previous precipitation events, and it incorporates the attenuation of soil moisture, coefficient $K$, which ranges from $0.6-0.9$, but is regionally 0.85 (The City of San Diego \& Geosyntec Consultants, 2018). 


\subsubsection{Study Site}

\subsubsection{Geographical location of study area}

Los Peñasquitos Creek (LPC) (Figure 3.1) is central to San Diego County, which lies in the south-western most province of California (32.30-33 N latitude, 117-118 W longitude) between the Pacific Ocean (west) and the Peninsular Mountain Range (east). The creek flows through two canyons and feeds into the Los Peñasquitos Lagoon (LPL), a coastal wetland that is critical habitat for aquatic organisms (Greer \& Stow, 2003). Weston Solutions Inc. (2009) found that Carroll Canyon Creek, followed by LPC have the greatest Total Mass Daily Loads (TMDL) and Total Suspended Solids (TSS) input in Los Peñasquitos Lagoon. Carroll Canyon sub watershed also has a greater urbanized to vegetated land-cover ratio than Los Peñasquitos which includes an open-space preserve, highlighted in green (Figure 3.1). The Peñasquitos watershed and preserve is under shared jurisdiction by the City and County of San Diego. 


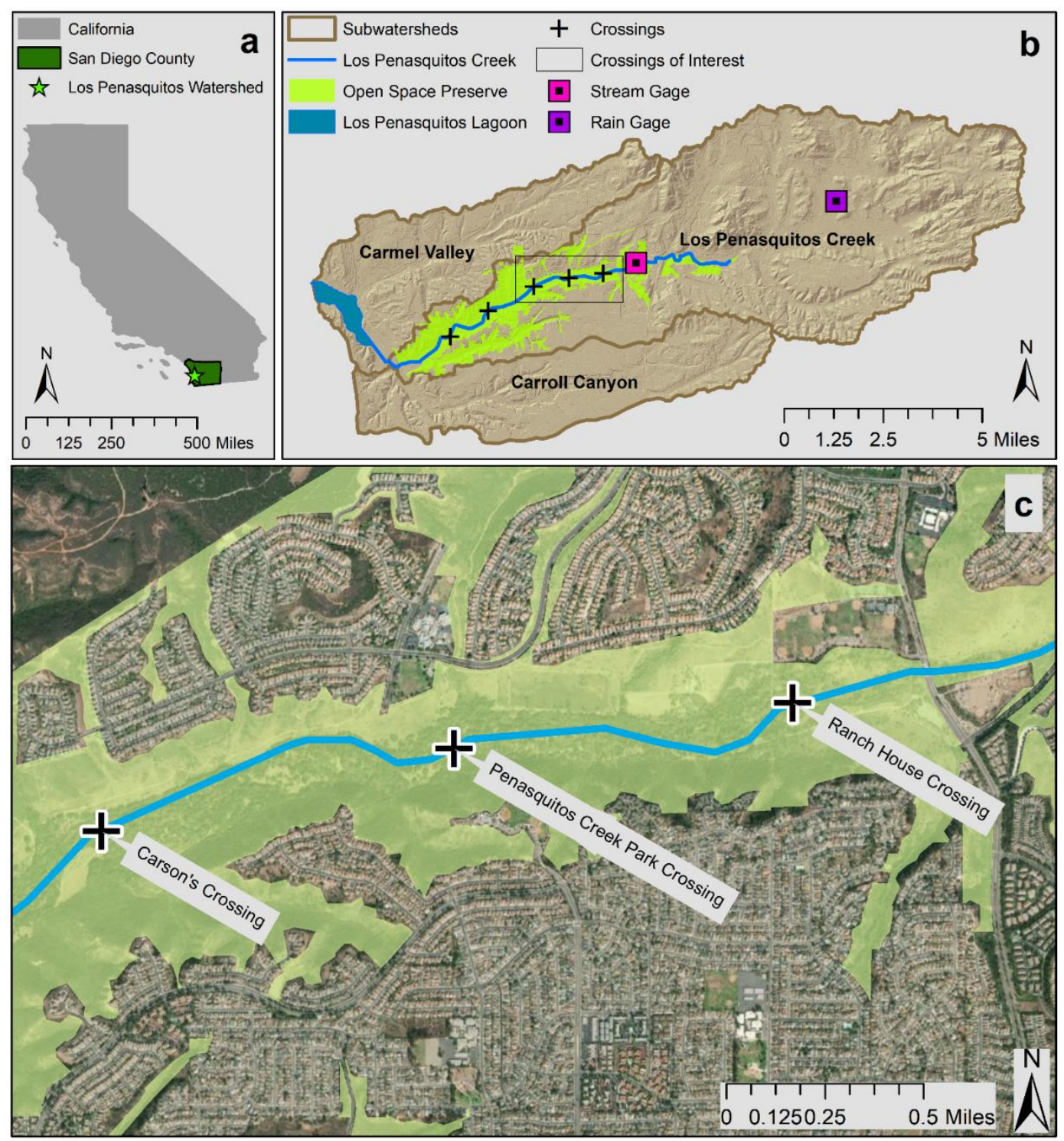

Figure 3.1 (a) Location of watershed within San Diego County, CA (b) Total watershed (-117.2599E - -116.9836E, 32.82913N-33.05549N) and Peñasquitos Sub-watersheds: Carmel Creek (north), Carroll Canyon (South), Los Peñasquitos Creek (LPC) (main). (c) The focus area for this study are the three creek crossings (County controlled) that are prone to damage from flooding (G. Washington, personal communication, August 27, 2020). 


\subsubsection{Climate of study area}

Climate in San Diego is characterized as semi-arid, Mediterranean with dry, hot summers and cool, wet winters (“California Climate Zone 7,” 1963) where annual precipitation is $\sim 25.5 \mathrm{~cm}$ (10 in.) (Figure 3.2). Historically, Los Peñasquitos Creek flow was intermittent due to these climatic conditions but is now perennial due to changes in Land Use/Land Cover (LU/LC) (Smith \& Kraft, 2013; White \& Greer, 2006).

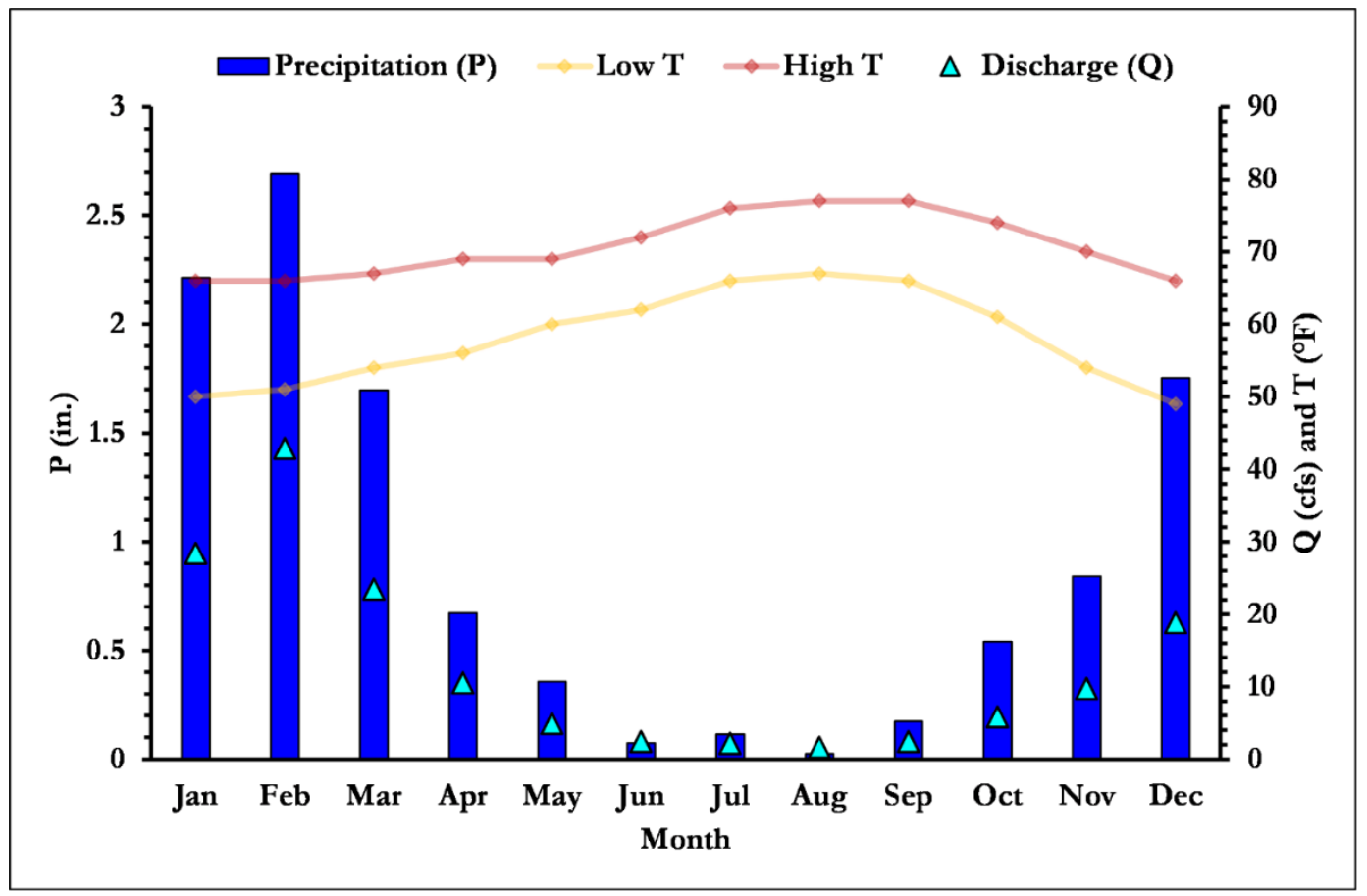

Figure 3.2 Local monthly averages (1989-2019) for climate variables: precipitation, low and high temperatures, and discharge.

Historically, San Diego has cycles of droughts and high rainfall. In a San Diego 50-year climate study by Messner, Miranda, \& Young (2011), the projected modeled scenarios had mixed results where half the scenarios resulted in wetter winters and the other half resulted in drier winters. However, climate models by Macdonald (2010) suggest prolonged droughts and river dependency for fresh water in the southwestern United States. 


\subsubsection{Local hydrological issues}

From 1973-2000, White \& Greer (2006) quantified a $28 \%$ increase in impervious surfaces that resulted in a $200 \%$ increase in runoff. Adding to this study, Bennett (2018) found an additional 8\% increase in urbanization by 2017. Furthermore, flow alteration has caused changes in salinity (Greer \& Stow, 2003) and sedimentation, (e.g. grain size, sediment load), which impact turbidity and influence leachability of pollutants (California Regional Water Quality Board, 2011; Weston Solutions Inc., 2009). Changes in sediment and flow can also affect habitat stability in rivers through erosional processes and morphologic modifications (Birtwell, 1999; Leopold \& Maddock, 1953; Voynova et al., 2017). Moreover, environmental sensitivity is heightened in areas with intermittent tidal flushing and restricted flows (California Department of Transportation, 2009) as well as intensified flows (Stein et al., 2017).

Though Los Peñasquitos Creek is surrounded by canyons and there are less residential communities directly in the floodplain compared to some other southern California coastal watersheds, there are several other sedimentary and ecologic impacts from general baseflow increase (including change from ephemeral to perennial flow) and flooding within the channel. This includes increases in sediment load and accretion, changes in morphology and water quality, increase in riparian vegetation (White \& Greer, 2006), and damage to current park infrastructure (G. Washington, personal communication, August 27, 2020). A main function of the watershed is recreation; however, visitors and campers influence the creek by changing flow patterns through damming, such as 
creating swimming ponds and crossings with logs and rocks. Finding and reverting these alterations, along with projects of removing introduced non-native vegetation (i.e. palm, willows, mule sap, and eucalyptus trees), and regular crossing and side trail repairs due to flooding have become a few of the issues that the Peñasquitos preserve management faces.

The watershed also provides habitat to over 500 plant species, 175 bird species, and several reptiles, amphibians, and mammals (Anderson \& Citizen Scientists, 2020). This function is put to risk by flow changes, both indirectly (contamination, sedimentation) and directly (morphologic). Preserve rangers have observed increases in flood extent and have had to repair train and trail crossing damages (G. Washington, personal communication, August 27, 2020). However, flooding has never been modeled for Los Peñasquitos Creek or nearby coastal canyon creeks. In coastal regions, much of the hydrologic modeling focuses on primary river networks, like flow-ecology impacts on the San Diego River (Stein et al., 2017); or impacts to estuaries, such as Tijuana River Estuary (Luke \& Sanders, 2017) and Los Peñasquitos Lagoon (Tague \& Pohl-costello, 2020). Considering the uncertainty and variability of a changing climate, but the certainty of increasing population, quantifying the risks to and from hydrologic processes is critical for economy, health, and sustainability (Gober, 2010). In efforts to help small, urban, coastal watershed management to improve watershed functions, this study aims to (1) determine the relationship between storm events and flow at Los Peñasquitos Creek using the Antecedent Precipitation Index (API) model and (2) map flood inundation extent for multiple Recurrence 
Intervals (RI-5, 10, 20, 50, 100) and climatic scenarios (IPCC RCP 2.6, 4.5, 6.0 and 8.5) ("IPCC, 2013: Summary for Policy Makers," 2013) for three crossings within the preserve. Together, these data could aid in developing a better monitoring plan for contaminant prone areas and for trail and stream crossing maintenance.

\subsection{Methods}

\subsubsection{Calculating RI Flows}

Velocity was measured in channel and discharge was calculated in order to ground-truth with summer flows from USGS gage (11023340 Los Peñasquitos C NR Poway CA). Fifteen-minute discharge (Q) from 1988-2020 data and the USGS peak flood frequency (PeakFQ) from 1965-2020 streamflow data (Table 3.1) was used to calculate RI-5, 10, 25, and 50 per methodology described in White \& Greer (2006). The USGS provides a single file of PeakFQ data which are annual peak discharges acquired from the USGS 15-minute data to estimate flood magnitude, variance, and annual exceedance probabilities (U.S. Geological Survey \& U.S. Department of the Interior, 2006). This data is commonly used to determine RI. The relationship between RI and flow was plotted and the following logarithmic equation was derived

$$
\text { Eq. } 1 \quad y=c * \ln (x)+b
$$

and used to estimate RI-100 and RI-500 flows, where $y$ is flow in cubic feet per second (cfs), $c$ is slope ( $y$ range, $\ln (x$ range $)), x$ is $\mathrm{RI}$, and $b$ is the intercept ( $y$ range, $\ln (x$ range $))$. RI-5, 10, 25, 50, and 100 were modeled using RAS-Mapper to estimate the inundated areas. 
Table 3.1 Data Sources

\begin{tabular}{|c|c|c|c|}
\hline Data & Description & Source & Link for citation purposes, not for table \\
\hline Terrain & San Diego 2016 DEM & SANDAG & $\begin{array}{l}\text { https://gis.sandag.org/sdgis/rest/services/El } \\
\text { evation/SanDiego_Regional_DEM/ImageS } \\
\text { erver }\end{array}$ \\
\hline \multirow[b]{2}{*}{ Shapefiles } & California & $\begin{array}{l}\text { US Census } \\
\text { Bureau }\end{array}$ & $\begin{array}{l}\text { https://ca.water.usgs.gov/sandiego/data/gis/ } \\
\text { WBD/index.html }\end{array}$ \\
\hline & $\begin{array}{l}\text { San Diego County } \\
\text { Watersheds and } \\
\text { Land Use }\end{array}$ & SANDAG & https://rdw.sandag.org/Account/gisdtview \\
\hline Discharge & $\begin{array}{l}\text { 1988-2020 15-min } \\
1965-2020 \text { PeakFQ }\end{array}$ & USGS & $\begin{array}{l}\text { https://waterdata.usgs.gov/nwis/inventory? } \\
\text { agency_code=USGS\&site_no }=11023340\end{array}$ \\
\hline Precipitation & $\begin{array}{l}\text { Gridded Daily 1948-2020 } \\
\text { CMIP5 Monthly and } \\
\text { Annual Extremes RCP } \\
\text { Projections } \\
1861-2100\end{array}$ & $\begin{array}{l}\text { NOAA } \\
\text { (Climate } \\
\text { Explorer. } \\
\text { KNMI) }\end{array}$ & https://climexp.knmi.nl/get_index.cgi \\
\hline Manning's n & N/A & $\begin{array}{l}\text { USDA } \\
\text { San Diego } \\
\text { Drainage } \\
\text { Design } \\
\text { Manual }\end{array}$ & $\begin{array}{l}\text { https://www.wcc.nrcs.usda.gov/ftpref/wnts } \\
\text { c/H\&H/roughness/wsp2339.pdf } \\
\text { https://www.sandiego.gov/sites/default/file } \\
\text { s/drainage design_manual_jan2017.pdf }\end{array}$ \\
\hline
\end{tabular}

\subsubsection{Estimating runoff from precipitation and CMIP5}

Climate models are used for projecting climate from atmosphere and ocean general circulation models. Other components that respond to climate changes and influence overall atmospheric and oceanic $\mathrm{CO}_{2}$ concentrations are also incorporated and referred to as coupled climate-carbon cycle models. The data models from around the world are used to predict future $\mathrm{CO}_{2}$ concentrations and climate from the current and historic fossil fuel $\mathrm{CO}_{2}$ emissions. (France, Willem, Friedlingstein, \& Munhoven, 2013). These data are the foundation to the Coupled Model Intercomparison Project Phase 5 (CMIP5). Gridded (-117.2599 - 116.9836E,_32.82913-33.05549N) annual maximum consecutive 5-day precipitation (denoted as 'rx5dayETCCDI' on the KNMI website) data from 1861-2100 (Table 3.1) was downloaded for RCP 2.6, 4.5, 6.0, 8.5.To estimate future flows using precipitation, a comparison between the observed winter total precipitation and the CMIP5 model means was made for the current period to 
demonstrate that the model means can provide reasonably good estimates. The CMIP5 winter total precipitation of the current, 1981-2000 period, and future climate scenarios, 2081-2100 was used to determine precipitation changes as the percent of current rainfall. "Transplanting" the observed daily precipitation data to the period of 2081-2100 was then justified to calculate streamflow using the multiple R equation acquired from the API model.

\subsubsection{Antecedent Precipitation Index (API)}

Used in several studies (Descroix et al., 2002; Kozlovská \& Toman, 2010; Sittner, Schaurss, \& Monro, 1969; Vinodkumar et al., 2017; Wen-ping \& Jingsong, 2013), the API method assumes that the influence of precipitation on runoff decreases with each day and is accordingly weighted in the calculation, with the strongest influence being from the most recent rainfall (Nikas et al., 2007):

$$
\text { Eq. } 2 \quad A P I=\operatorname{sum}\left[\left(K^{i}\right) P_{i}\right]
$$

where $\mathrm{K}$ is the regional attenuation coefficient, 0.85 for San Diego (The City of San Diego \& Geosyntec Consultants, 2018; Zhao, Wei, Yang, \& Jiang, 2011), $i$ is the number of days prior to day-of peak flow, and $\mathrm{P}$ is precipitation. To determine the strength of the relationship between runoff and precipitation within the gridded area, a multiple regression analysis was used, where the dependent variable is PeakFQ plotted against the independent variables, API and P.

A hydrograph was created for each PeakFQ date with precipitation up to one month prior and a few days after. For many peak discharge occurrences, 15days prior to the PeakFQ date is when precipitation occurred and could have led to initial soil saturation. Precipitation data showed higher precipitation occurring 
the day-after PeakFQ, and we confirmed that gage reading for this region was done over a 24-hour period rather than at the end of the day. For this reason, API was calculated for 15 -days before and 14 -days before plus 1 day after $(-14,+1)$ to account for the discrepancy in gage reading time. Both were calculated and statistically checked. We decided that including the precipitation from the day after was necessary to best correlate $\mathrm{P}: \mathrm{Q}$. This confirmed that precipitation does in-fact influence discharge. We also calculated API for 10-days (-9+1) and 5-days $(-4+1)$, giving us 4 total API and precipitation variables. The precipitation value was taken for the P on the PeakFQ date, the Peak P in 3-day period within the 15day API and the Peak P within the 3-day period in the $-14+1$, and Peak-P that occurred within a consecutive rainfall. After climate considerations and comparisons of the 4 API and 4 precipitation variables, using the API 5-day range with Peak $\mathrm{P}$ in a consecutive rainfall resulted in the highest multiple $\mathrm{R}(0.7114)$ and lowest P-values (intercept:0.0153, precipitation variable:0.0129, API variable:0.0083).

Ultimately using the multiple R equation (Eq.3) to project future flows based on projected rainfall changes within the study site grid, we first calculated RCP 2.6, 4.5, 6.0 and RCP 8.5 period means (2081-2100:1981-2000) from gridded daily CMIP5 annual extremes projections data from NOAA. The difference of those means for each scenario were calculated. The original observed rainfall data is interpolated and adjusted to the respective percentage increase from the difference of means. This methodology is simplified from an empirical method used in rainfall modeling by Zou, Dai, Wu, Yang, \& Zhang 
(2020). The projected rainfall was then entered in the multiple regression model, which was used to estimate future flows under RCP 2.6, 4.5, 6.0, and 8.5.

\subsubsection{Modeling}

The Hydrologic Engineering Center's River Analysis System (HEC-RAS) software, ArcGIS, and the RAS Mapper tool (in HEC-RAS) were used to evaluate the research questions, RAS Mapper software is used to model flow profiles and create a flood inundation map (Mokhtar, Pradhan, Ghazali, Zulhaidi, \& Shafri, 2018). A 3-meter Digital Elevation Model (DEM) was downloaded from USGS (Table 3.1) and clipped to the watershed. The DEM was used as the surface for running steady-flow analysis. Channel Gradient, needed for the model, was calculated by extracting channel Z-values from the DEM.

River geometry data was digitized in ArcGIS using field surveyed coordinates, aerial imagery, and the DEM. All features were edited from upstream to downstream and left bank to right bank for consistency in RAS-Mapper. The RI-calculated flows were used in steady-flow analysis within HEC-RAS (Wang et al., 2018). Steady-flow analysis is used for steady, gradually varied, or constant and laminar flow of water. This one-dimensional steady-flow model is commonly used in flow analyses of limited channel length because flow does not change and the solutions for either steady or unsteady state will be the same. The simplified inputs for steady-flow analysis is discharge, downstream stages, and Manning's $n$. Then, the program computes elevation, discharge, velocity, and energy slope across each cross section created (Wang et al., 2018). 


\subsection{Results}

\subsubsection{Recurrence Interval Flow Projections}

Annual PeakFQs used to determine frequency, probability, and recurrence intervals (RI) and highlight the changes over the data period. The probability of normally low-chance flows has been increasing since the 1960's (Figure 3.3a). There were only three flow (Q) occurrences within the $20 \%$ probability in the 1960-1990 period. When we compare to the $1990-2020$ period, this increases to eight occurrences, three of which were within $5 \%$ probability in more recent years.

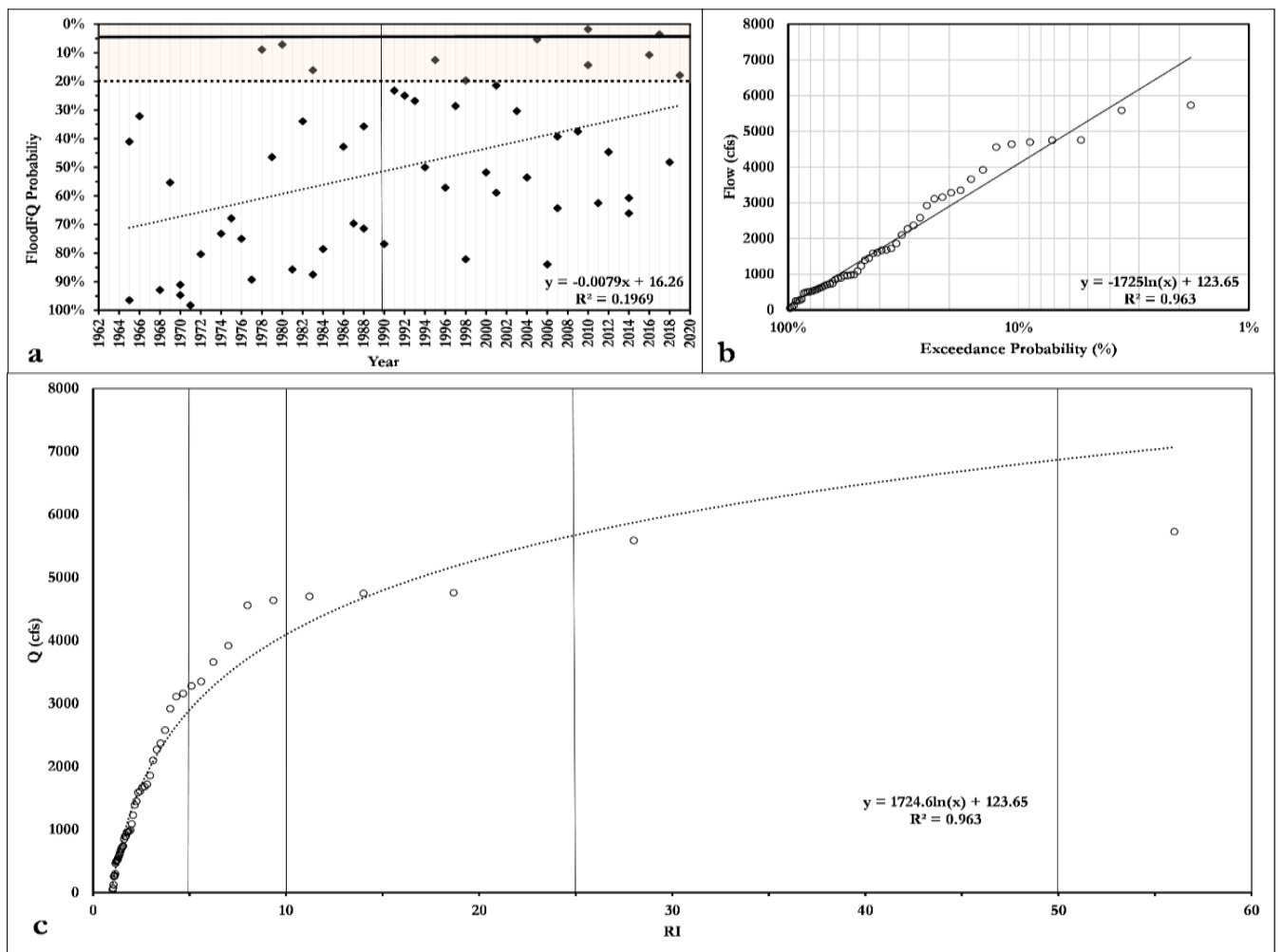

Figure 3.3 (a) Los Peñasquitos Watershed PeakFQ probability frequency increase from approximately two 30-yr periods, 1965-1990 vs 1990-2020. The dotted-line represents a $20 \%$ probability, the bolded-line represents a $5 \%$ probability that a low-chance high-flow event will occur. The probability of these flow events which previously had a $<20 \%$ chance of occurring have nearly tripled in the last 30-years. (b) Los Peñasquitos Creek flow exceedance probability and Recurrence Interval (RI) using PeakFQ data (c) RI vs Flow (Q), equation used for future estimates. 
Recurrence Intervals (RI) (Table 3.2) were calculated from the PeakFQ data. RI-100 and RI-500 were approximated per the logarithmic equation in Figure 3.3, $y=1724.6 \ln (x)+123.65$, where $y$ is flow (cfs) and $x$ is RI. The estimated flows for RI-5, 10, 25, 50, 100, and 500 (Table 3.2) were entered in the steady-flow in HEC-RAS to model the flood extent, three of which were compared (Figure 3.4). Channel width, measured from the modeled flows, increase with higher flows (Table 3.2) but to different magnitudes at each creekcrossing.

Table 3.2 Recurrence Intervals calculated from PeakFQ and estimated channel width extent over right bank (R) and over left bank (L) for selected creek-crossings.

\begin{tabular}{|c|c|c|c|c|c|c|c|c|}
\hline \multicolumn{2}{|l|}{ RI } & Bank & $5-\mathrm{yr}$ & $10-y r$ & 25-yr & $50-\mathrm{yr}$ & $100-y r$ & 500-yr \\
\hline \multicolumn{2}{|c|}{ Observed Flow (cfs) } & & 3,280 & 4,670 & 5,175 & 5,730 & - & - \\
\hline \multicolumn{2}{|c|}{ Estimated Flow (cfs) } & & 2,899 & 4,095 & 5,675 & 6,870 & 8,066 & 10,841 \\
\hline \multirow{6}{*}{$\begin{array}{l}\text { Estimated } \\
\text { Increase } \\
\text { (ft) }\end{array}$} & Ranch House & $\mathrm{R}$ & 1,041 & 1,059 & 1,066 & 1,070 & 1,080 & 1,112 \\
\hline & Crossing & $\mathrm{L}$ & 218 & 227 & 227 & 227 & 236 & 259 \\
\hline & Peñasquitos & $\mathrm{R}$ & 109 & 135 & 149 & 156 & 191 & 405 \\
\hline & Creek Crossing & $\mathrm{L}$ & 79 & 122 & 454 & 469 & 492 & 498 \\
\hline & Carson's & $\mathrm{R}$ & 178 & 241 & 278 & 289 & 305 & 356 \\
\hline & Crossing & $\mathrm{L}$ & 181 & 211 & 221 & 248 & 278 & 280 \\
\hline
\end{tabular}




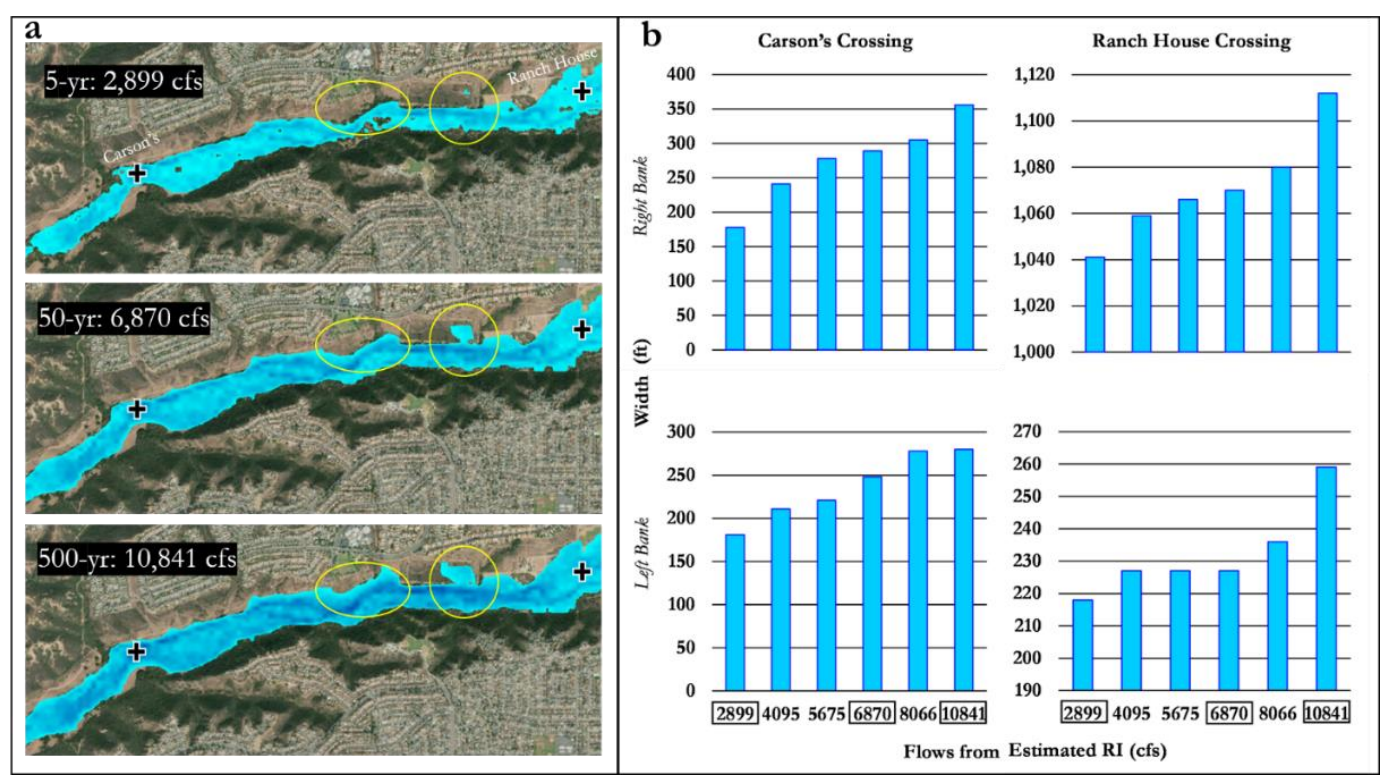

Figure 3.4 (a) RI-5, 2899 cfs (like peak winter flow of 2018-2019, 3350 cfs); RI50, 6870 cfs; RI-500, 10,841 cfs. Plus signs represent crossings and darker shades represent greater depth. Carson's Crossing (left) shown downstream of Ranch House Crossing (right). Circled areas show most prominent inundation from increased flow (b) Channel width enlargement for marked crossings, where right bank is to the north side of the creek and left bank is south.

\subsubsection{RCP Modeled Flow Projections}

As a result of model averaging for CMIP5 data, projected annual P data points have less variability compared to observed rainfall during the 1965-2019 period (Figure 3.5). Each RCP scenario has an overall positive slope across the 1965-2100 timeline, where RCP 2.6 and $4.5=0.0293$, RCP $6.0=0.0302$, and $\operatorname{RCP} 8.5=0.0467$. 


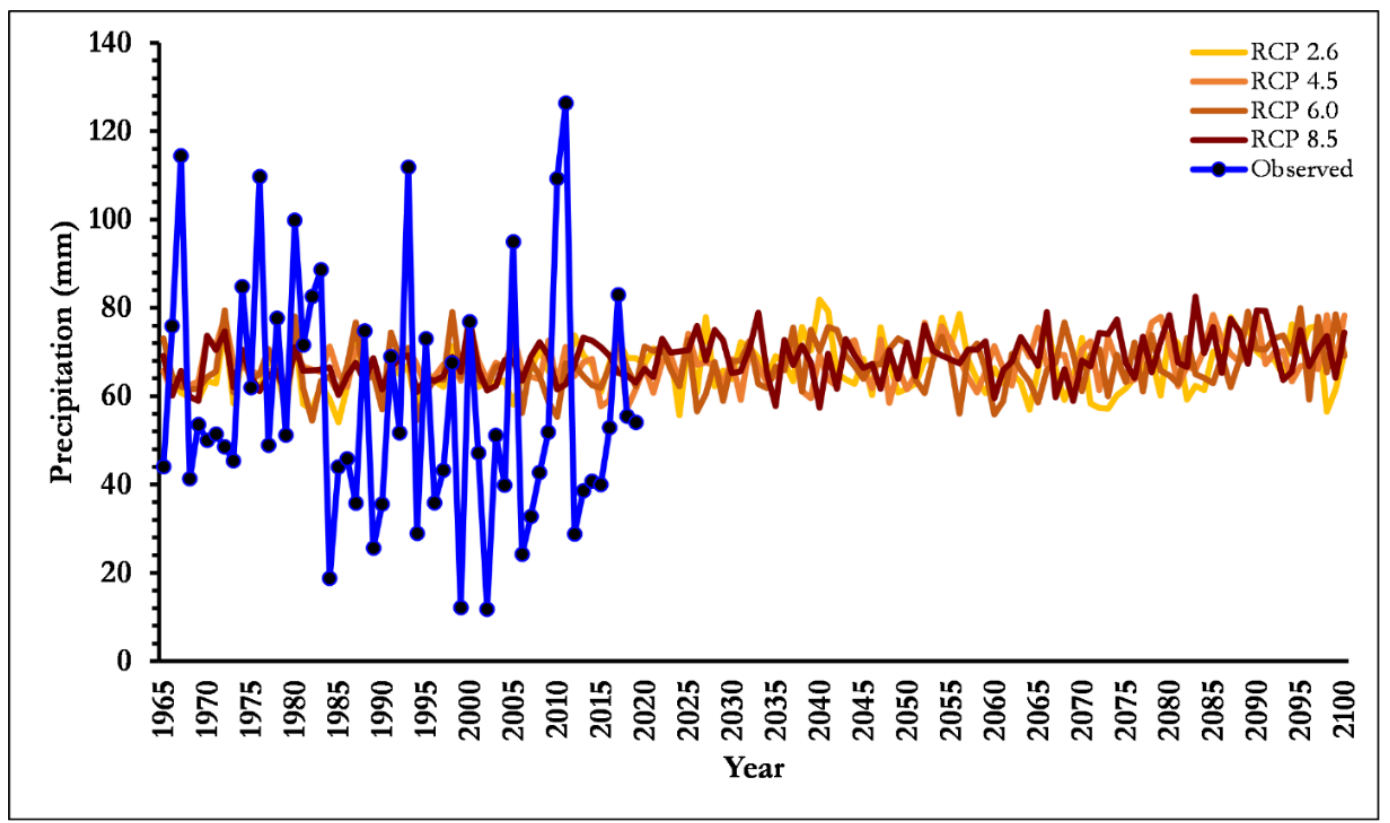

Figure 3.5 Projected annual precipitation (P) extremes (1965-2100) versus Observed 5-day rainfall (1965-2019).

In the averages and difference of means from Table 3.3, the projections have lower variability averaging between only 69-71 $\mathrm{mm}$ for each scenario. Approximation from the observed series would project rainfall to be between 119$124 \mathrm{~mm}$, which agrees with the 'transplant' method (Table 3.3). The following Multiple R-equation was acquired from observed rainfall data:

$$
\text { Eq. } 3 \quad Y=-1046.8379+1132.2457(P)+906.1939(A P I)
$$

where the dependent variable is flow, $Y$, and the independent variables are precipitation, $P$ (in.), and API giving a multiple $\mathrm{R}$ of 0.71 and $\mathrm{p}$-value $<0.02$. For projecting future flows, we use the equation where the independent variable for API is 5-day to best represent the projected RX5 rainfall data. Projected precipitation is a 5-day sum, so 5-day sums of observed peak-flow rainfall was calculated to 'transplant' into the RCP scenarios. The peak rainfall from that new 
series was then used in calculating an API (Eq. 2) and estimated the corresponding flow (Eq. 3) (Table 3.3).

Table 3.3 Adjusted RCP peak precipitation ( $\mathrm{mm}$ ) estimates, transplanted to multiple regression equation (Eq.2) to calculate future flows.

\begin{tabular}{|l|l|l|l|l|}
\hline & RCP 2.6 & RCP 4.5 & RCP 6.0 & RCP 8.5 \\
\hline 2081-2100 & 69.0 & 69.9 & 69.7 & 71.6 \\
\hline 1981-2000 & 63.9 & 66.9 & 65.3 & 66.0 \\
\hline \% increase & $8.1 \%$ & $4.5 \%$ & $6.8 \%$ & $8.4 \%$ \\
& \multicolumn{1}{|c|}{ Observed Series 'Transplant' into Scenario } \\
\hline P (mm) & 123.6 & 119.6 & 122.2 & 124.1 \\
\hline P (in.) & 4.9 & 4.7 & 4.8 & 4.9 \\
API & 4.1 & 4.0 & 4.1 & 4.2 \\
\hline Flow Est.(cfs): & $\underline{8214.8}$ & $\underline{7908.0}$ & $\underline{8105.5}$ & $\underline{8245.6}$ \\
\hline
\end{tabular}

Under each RCP model, the estimated flow is higher than the RI 100-year predictions. With current data, there has not yet been a 100-year flow. With modeled data, the projections estimate that flows will consistently be in the 5-10year RI range (Figure 3.4).

\subsection{Discussion}

Mean discharge for winter and summer months fluctuate from 1988-2020 and there is no overall increasing trend. However, there is an increasing trend in the annual maximum discharge (Figure 3.3) which is not reflected in current RI because of how they are calculated using only historic recordings. Regardless of the RI and increasing flows (Figure 3.4), canyon shape will eventually limit channel enlargement (Table 3.2). Increased depths in several constricted channel areas are illustrated in Figure 3.4a. Additionally, this level of water volume flowing through a constricted canyon would force an increase in channel velocity and erosion (Bierman \& Montgomery, 2020) upstream, thus impacting material transport and ecology (Stein et al., 2017) downstream. The slope of the central part of the canyon (Figure 3.1c) decreases and the channel widens even during 
the low flow season from field surveys taken in the summer. During high flow, this area is most prone to channel widening and material deposition from the lack of constriction and shallowing of slope. Furthermore, transportation and deposition of sediment or structural elements (e.g., woody debris) causes changes to geomorphic features (e.g., pools, riffles, bars, eddies) (Wheaton et al., 2015). In addition to natural geomorphic forcing, this region is part of the open-space preserve that is prone to anthropogenic forcing of flow (i.e., by moving around rocks and branches to create personal swimming pools or creek crossings) (G. Washington, personal communication, August 27, 2020). This not only alters the natural hydrology but creates challenges for management.

However, these structural changes can also be beneficial and help create retention pools for overflow, allowing aquatic organisms to find refuge during high-flow events (Fausch \& Bramblett, 1991; Pasternack, Bounrisavong, \& Parikh, 2008). These scour pools remain during low flow season and have been spotted throughout the creek. The Los Peñasquitos Lagoon is often revered for providing refuge to species, but the function of creeks also providing refuge should not be overlooked - especially near Ranch House Crossing, where overflow pools are deep enough for aquatic organisms to inhabit throughout the year.

In comparing the observed and projected data (Figure 3.5), we see that the projected models have smaller variability which can be attributed to the averaging of results from multiple models. There is a $50 \%$ chance that this region will be subject to wetter winters (Messner et al., 2011), so the overlap of RCP scenarios 
ranging from $4.5 \%-8.4 \%$ increased precipitation should not be ignored because it addresses the variability and magnitude of actual rainfall patterns. Overall, the variability between RCP scenarios was low and comparable to each other (Table 3.3).

When scenarios were applied to projected precipitation flow calculations, while they were comparable to the RI 100-year flows (Table 3.2), 3 of the 4 scenarios resulted in higher flow estimates. This is another reason that confirms that flow magnitude for the respective, previously calculated RI may be changing and addresses how RI, while comparable, is based on past data and may not be the best method going forward. Flood maps need to incorporate future projections based on their study area projections for both precipitation and urbanization. However, for this site, the variability and inconsistency of observed patterns allows these projections to be within reason. In other locations that do not experience drought-storm patterns, this may not be the case.

The relationship between increased development and flow is welldocumented (Conway, 2005; Du et al., 2012; Hawley \& Bledsoe, 2011; Miller et al., 2014; Salvadore et al., 2015; White \& Greer, 2006); even slight increases in impervious surfaces were interpreted as severe hydrologic alteration in a San Diego River case study (Stein et al., 2017) that found >5\% impervious cover resulted in hydrologic alteration. At Los Peñasquitos Watershed, a supplemental study by Bennett (2018) found an additional $8 \%$ increase in impervious surfaces to work by White \& Greer (2006) which quantified $200 \%$ increase in flow from 1973-2000. Figure 3.4 shows that as flows increase, flood-extent and channel 
width also increase. At the first crossing, flooding encroaches the baseball park at RI-5 flows (Figure 3.4b). This is useful for future development planning because parks are low-risk areas that can provide retention for overflows. The channel flows within the canyon where developments exist on either side. Storm drainage and further development could potentially exacerbate downstream flows. This can lead to unfavorable consequences for instream fauna especially in localized velocity zones (Stein et al., 2017).

The duration (days between low and high threshold), magnitude (max monthly mean flow), variability (flashiness), and frequency (median number of events that flow was greater than threshold) are a few of the variables that have been studied for estimating flow (Hawley \& Bledsoe, 2011; Mazor et al., 2018; Stein et al., 2017). These four variables were not analyzed due to the scope of this study, however preliminary data suggests there is indication that increased frequency and/or intensity of rainfall is a contributor to an increase in future high flows due to soil saturation and not enough time between high rainfalls to evaporate. Stein et al. (2017) also found that deforestation at the San Diego River reduced the water storage capacity and uptake, so the effects of future land-use can certainly have an impact at Los Peñasquitos Watershed. Regional flow criteria have been developed with different climatic cycles in mind, however, they do not necessarily account for the future climatic patterns or episodic and frequent events at a regional scale, as seen in Figure 3.5. This is especially important to better maintain habitats, particularly in protected areas that are home to several native species (Stein et al., 2017) and endangered plant species like those at Los 
Peñasquitos Preserve (G. Washington, personal communication, August 27, 2020). Under 2050 land-use projections by SanGIS, Stein et al. (2017) predicts that the middle reach will be most hydrologically altered especially degraded in smaller catchments.

An effective solution to mitigation of flow impacts, recommended by Mazor et al. (2018) is by assessing regional impacts, setting flow target zones, and managing the hydrologic alteration areas, as opposed to mitigating actual stressors, such as flow input. There are currently no storage areas (G. Washington, personal communication, August 27, 2020) which could be a useful mitigation effort for the middle area (Figure 3.1 and Figure 3.4). In times of drought and low flow season, Mazor et al. (2018) found that there was an association with decreased macroinvertebrate communities (possibly due to increased predation). Changes in flow flashiness, and duration of high and low flow events caused the numbers of these communities to decrease most when compared to other variables (Stein et al., 2017).

Some limitations of this study include limited gaging sites and sediment transport data. Without these, it can be challenging to accurately assess impacts at each specific site. Estimating flow conditions at ungauged sites is important in order to account for the local geographic variability and frequently missed relationships (Mazor et al., 2018). Velocity was measured to calculate discharge, which was then used to compare with gage readings. The numbers used in the model are conservative because $\mathrm{Q}$ increases downstream within the middle reach of the preserve (Figure 3.1). For estimating flow through rainfall, creating models 
is challenging due to the stochastic nature of hydrology, fluvial geomorphology, and future uncertainties with climate and urban growth. Increased rainfall and runoff also result in increased vegetation growth. Often, this can result in increased infiltration capacity (Descroix et al., 2002) and potential flow dispersion or impoundment (Pietsch \& Nanson, 2011); however, at Los Peñasquitos Canyon Preserve, there is no strong evidence of natural impoundment or groundwater discharge into streamflow (Bennett, 2010; City of San Diego, 2011; HELIX Environmental Planning, 2015). The duration, magnitude, variability, and frequency of rainfall as well and soil moisture loss from evaporation/evapotranspiration (Vinodkumar et al., 2017) are important factors for predicting flow, but was only measured to a limited capacity through the API model. Future work should include assessing these variables as well as modeling the sediment transport and the deposition patterns.

\subsection{Conclusion}

Los Peñasquitos Watershed's (LPW) PeakFQ has been gradually increasing, where more frequent, low-probability events are occurring regularly. This is an indicator that flows for Recurrence-Intervals periods may always be conservative since those calculations rely on long-term records, that does not account enough for current or future trends due to limited data. This is especially relevant for LPW because from 1973-2000, urbanization had increased from 9$37 \%$, causing runoff to increase $>200 \%$ (White $\&$ Greer, 2006) and an additional 8\% increase occurred from 2000-2017 (M. Bennett, 2018). Flows in the RI-5 range have been occurring anywhere from every couple of years to multiple times 
in one year. Flow models show which areas are prone to overflow and could use mitigation to manage the hydrologic alteration in a high-flow event.

Since runoff at LPW is associated with rainfall patterns (White \& Greer, 2006), we used rainfall to estimate flow. In urban areas, flooding is closely associated with short-duration, high-intensity rainfall (Kulkarni et al., 2014). We confirmed this with LPW by multiple regression using the API-method for 5-day sums and peak precipitation over a consecutive rainfall period.

When compared to observed rainfall, RCP models for 5-day sums have low variability due to averaging of models. To account for the variability, transplanting observed data to the average means percent change (from 19812000 and 2081-2100) provided more realistic outcomes. The predicted flows are still conservative due to limitations of knowing future land-cover change and population growth. RCP scenarios overlap with each other because of the uncertainty in predicted rainfall under each scenario (Messner et al., 2011) but we provide a theoretical estimate to plan for $\sim 8,250$ cfs flows between the next $50-80$ years, with increased frequency of these high flows within the range. In an semiarid region, it is especially important to be cognizant for development because high-evaporation summers encourage management to ignore the potential risks of infrequent high flows (Bekhira et al., 2019), but this should not be considered high priority because both drought and intense flows can have a high impact on ecologic communities, sedimentation, and watershed quality. 


\subsection{Acknowledgements}

This work was supported by a USD Faculty Research Grant 2019 to S. Walther. The authors wish to thank San Diego City Parks and Recreation Department for permitting, specifically Ranger Gina Washington for site access, knowledge and support for the study done at Los Peñasquitos Creek. 


\subsection{References}

Anderson, J., \& Citizen Scientists. (2020). About Nature. Retrieved from https://www.penasquitos.org/about-nature-preserve\#habitats

Bekhira, A., Habi, M., \& Morsli, B. (2019). Management of Hazard of Flooding in Arid Region Urban Agglomeration Using HEC-RAS and GIS Software: The Case of the Bechar's City. Journal of Water and Land Development, 42(7-9), 21-32. https://doi.org/10.2478/jwld-2019-0041

Bennett, J. (2010). General Plan Update Groundwater Study. County of San Diego: Department of Planning and Land Use. Retrieved from https://www.sandiegocounty.gov/content/dam/sdc/pds/gpupdate/docs/BOS_ Aug2011/EIR/Appn_D_GW.pdf

Bennett, M. (2018). Quantifying the Effects of Watershed Urbanization on the Hydrology and Channel Morphology in Los Peñasquitos Reserve. [Conference Presentation Abstract].

Bierman, P. R., \& Montgomery, D. R. (2020). Drainage Basins. In Key Concepts in Geomorphology (2nd ed., pp. 239-270). New York: MacMillan Learning.

Birtwell, I. K. (1999). The Effects of Sediment on Fish and their Habitat. Retrieved from http://www.dfo-mpo.gc.ca/Library/240698.pdf

California Climate Zone 7. (1963). Retrieved from https://www.pge.com/includes/docs/pdfs/about/edusafety/training/pec/toolbo x/arch/climate/california_climate_zone_07.pdf

California Department of Transportation. (2009). Los Peñasquitos Creek Location Hydraulic Study. Retrieved from

https://www.keepsandiegomoving.com/Documents/NCC_doc/EIR/Supportin g/3.09_Hydrology/Los_Peñasquitos_Creek_Location-Hydraulidc-StdyMar09.pdf

California Regional Water Quality Board. (2011). Hydrology and Water Quality. San Diego. Retrieved from https://www.waterboards.ca.gov/sandiego/

Chatterjee, S. (2018). Projected climate change impacts on hydrologic flow regimes in the Great Plains of Kansas. River Research Applications, 34, 195206. https://doi.org/10.1002/rra.3249

Chen, J., \& Kumar, P. (2001). Topographic influence on the seasonal and interannual variation of water and energy balance of basins in North America. Journal of Climate, 14(9), 1989-2014. https://doi.org/10.1175/1520-0442(2001)014<1989:TIOTSA>2.0.CO;2

City of San Diego. (2011). Hydrology and Water Quality. Retrieved from https://www.sandiegocounty.gov/content/dam/sdc/pds/gpupdate/docs/BOS_ Aug2011/EIR/FEIR_2.08_-_Hydrology_2011.pdf

Conway, T. M. (2005). Current and Future Patterns of Land-Use Change in the Coastal Zone of New Jersey. Environment and Planning B: Planning and Design, 32, 877-893. https://doi.org/10.1068/b31170

Descroix, L., Nouvelot, J., \& Vauclin, M. (2002). Evaluation of an Antecedent Precipitation Index to Model Runoff Yield in the Western Sierra Madre (North-West Mexico). Journal of Hydrology, 263, 114-130.

Dettinger, M. D., \& Diaz, H. F. (2002). Global Characteristics of Stream Flow 
Seasonality and Variability. Journal of Hydrometeorology, 1(4), 289-310. https://doi.org/10.1175/1525-7541(2000)001<0289:gcosfs>2.0.co;2

Du, J., Qian, L., Rui, H., Zuo, T., Zheng, D., Xu, Y., \& Xu, C. Y. (2012). Assessing the Effects of Urbanization on Annual Runoff and Flood Events Using an Integrated Hydrological Modeling System for Qinhuai River Basin, China. Journal of Hydrology, 464-465, 127-139.

https://doi.org/10.1016/j.jhydrol.2012.06.057

Fausch, K. D., \& Bramblett, R. G. (1991). Disturbance and Fish Communities in Intermittent Tributaries of a Western Great Plains River Published by : American Society of Ichthyologists and Herpetologists ( ASIH ) Stable URL : https://www.jstor.org/stable/1446392. Copeia, 3, 659-674.

FEMA. (n.d.). All About Flood Maps. Retrieved October 18, 2019, from https://www.floodsmart.gov/why/all-about-flood-maps

France, P. C., Willem, J., Friedlingstein, P., \& Munhoven, G. (2013). Carbon and Other Biogeochemical Cycles 6.

Gober, P. (2010). Desert urbanization and the challenges of water sustainability. Current Opinion in Environmental Sustainability, 2(3), 144-150. https://doi.org/10.1016/j.cosust.2010.06.006

Greer, K., \& Stow, D. (2003). Vegetation Type Conversion in Los PEñasquitos Lagoon, California: An Examination of the Role of Watershed Urbanization. Environmental Management, 31(4), 489-503. https://doi.org/10.1007/s00267-002-2849-6

Hawley, R. J., \& Bledsoe, B. P. (2011). How Do Flow Peaks and Durations Change in Suburbanizing Semi-Arid Watersheds? a Southern California Case Study. Journal of Hydrology, 405(1-2), 69-82. https://doi.org/10.1016/j.jhydrol.2011.05.011

Hawley, R. J., \& Bledsoe, B. P. (2013). Channel enlargement in semiarid suburbanizing watersheds : A southern California case study. Journal of Hydrology, 496, 17-30. https://doi.org/10.1016/j.jhydrol.2013.05.010

HELIX Environmental Planning. (2015). Final Los Penasquitos Canyon Preserve Wetland Enhancement.

IPCC, 2013: Summary for Policy Makers. (2013). Climate Change: The Physical Science Basis. Contribution of Working Group I to the Fifth Assessment Report of the Intergovernmental Panel on Climate Change [Stocker, T.F., D. Qin, G.-K. Plattner, M. Tignor, S.K. Allen, J. Boschung, A. Nauels, Y. Xia, V. $B$.

Kochel, R. C., Miller, J. R., \& Ritter, D. F. (1997). Geomorphic response to minor cyclic climate changes, San Diego County , California, 19, 277-302.

Koster, R. D., Guo, Z., Yang, R., Dirmeyer, P. A., \& Mitchell, K. (2009). On the Nature of Soil Moisture in Land Surface Models. Journal of Climate, 22, 4322-4336. https://doi.org/10.1175/2009JCLI2832.1

Kozlovská, S., \& Toman, F. (2010). Antecedent precipitation index evaluation at chosen climatological stations, 135-140.

Kulkarni, A. T., Eldho, T. I., Rao, E. P., \& Mohan, B. K. (2014). An Integrated Flood Inundation Model for Coastal Urban Watershed of Navi Mumbai, India. Natural Hazards, 73, 403-425. https://doi.org/10.1007/s11069-014- 
1079-6

Leopold, L. B., \& Maddock, T. (1953). The Hydraulic Geometry of Stream Channels and Some Physiographic Implications. Geological Survey. Washington, D.C. Retrieved from https://pubs.usgs.gov/pp/0252/report.pdf

Luke, A., \& Sanders, B. (2017). FloodRISE Mapping Methods for the Tijuana River Valley and Goat Canyon Watershed.

Macdonald, G. M. (2010). Water, climate change, and sustainability in the southwest. Proceedings of the National Academy of Sciences of the United States of America, 107(50), 21256-21262. https://doi.org/10.1073/pnas.0909651107

Mazor, R. D., Mccune, S., May, J. T., Bledsoe, B. P., \& Stein, E. D. (2018). Tools for Managing Hydrologic Alteration on a Regional Scale: Setting Targets to Protect Stream Health. Freshwater Biology, (December 2017), 786-803. https://doi.org/10.1111/fwb.13062

Meixner, T., Manning, A. H., Stonestrom, D. A., Allen, D. M., Ajami, H., Blasch, K. W., ... Walvoord, M. A. (2016). Implications of Projected Climate Change for Groundwater Recharge in the Western United States. Journal of Hydrology, 534, 124-138. https://doi.org/10.1016/j.jhydrol.2015.12.027

Messner, S., Miranda, S. C., \& Young, E. (2011). Climate Change-Related Impacts in the San Diego Region by 2050. Climate Change, 109(Suppl 1), 505-531. https://doi.org/10.1007/s10584-011-0316-1

Miller, J. D., Kim, H., Kjeldsen, T. R., Packman, J., Grebby, S., \& Dearden, R. (2014). Assessing the Impact of Urbanization on Storm Runoff in a PeriUrban Catchment Using Historical Change in Impervious Cover. Journal of Hydrology, 515, 59-70. https://doi.org/10.1016/j.jhydrol.2014.04.011

Mokhtar, E. S., Pradhan, B., Ghazali, A. H., Zulhaidi, H., \& Shafri, M. (2018). Assessing flood inundation mapping through estimated discharge using GIS and HEC-RAS model. Arabian Journal of Geosciences, 11(682). https://doi.org/10.1007/s12517-018-4040-2

Nikas, K., Antonakos, A., Lambrakis, N., \& Kallergis, G. (2007). The Use of "Antecedent Precipitation Index" and "Delay Factor" to Estimate Runoff From Rainfall; A Case Study From Eight Drainage Basins-Achaia, Peloponessos, Greece. Bulletin of the Geological Society of Greece, 37(June 2015).

Nikolic, N., Kostic, L., \& Nikolic, M. (2018). To dam, or not to dam? Abolishment of further flooding impedes the natural revegetation processes after long-term fluvial deposition of copper tailings. Land Degradation and Development, 29(6), 1915-1924. https://doi.org/10.1002/ldr.2921

Pasternack, G. B., Bounrisavong, M. K., \& Parikh, K. K. (2008). Backwater control on riffle - pool hydraulics, fish habitat quality , and sediment transport regime in gravel-bed rivers. Journal of Hydrology, 125-139. https://doi.org/10.1016/j.jhydrol.2008.05.014

Pietsch, T. J., \& Nanson, G. C. (2011). Geomorphology Bankfull Hydraulic Geometry; The Role of In-Channel Vegetation and Downstream Declining Discharges in the Anabranching and Distributary Channels of the Gwydir Distributive Fluvial System, Southeastern Australia. Geomorphology, 129(1- 
2), 152-165. https://doi.org/10.1016/j.geomorph.2011.01.021

Salvadore, E., Bronders, J., \& Batelaan, O. (2015). Hydrological Modelling of

Urbanized Catchments: A Review and Future Directions. Journal of

Hydrology, 529(P1), 62-81. https://doi.org/10.1016/j.jhydrol.2015.06.028

Sittner, W. T., Schaurss, C. E., \& Monro, J. C. (1969). Continuous Hydrograph Synthesis with an API-Type Hydrologic Model. Water Resources Research, 5(5), 1007-1022.

Smith, B. F., \& Kraft, J. R. (2013). A Cultural Resources Study for the Los Peñasquitos Adobe Drainage Project, San Diego County, California (CSD04.03). San Diego. Retrieved from https://www.sandiegocounty.gov/reusable_components/images/dgs/Documen ts/CEQA_LPAdobeExhibitB.pdf

Smith, J. N., \& Schafer, C. T. (1999). Sedimentation, Bioturbation , and Hg Uptake in the Sediments of the Estuary and Gulf of St . Lawrence. Limnology and Oceanography, 44(1), 207-219.

Sridhar, V., Billah, M. M., \& Hildreth, J. W. (2018). Coupled Surface and Groundwater Hydrological Modeling in a Changing Climate. Groundwater, 56(4), 618-635. https://doi.org/10.1111/gwat.12610

Stein, E. D., Mazor, R. D., Mccune, K., Bledsoe, B. P., \& Adams, S. (2017). Application of Regional Flow - Ecology Relationships to Inform Watershed Management Decisions: Application of the ELOHA Framework in the San Diego River Watershed, California, USA. Ecohydrology, (January), 1-16. https://doi.org/10.1002/eco.1869

Stromberg, J. C., Beauchamp, V. B., Dixon, M. D., Lite, S. J., Paradzick, C., Services, E., \& Project, S. R. (2007). Importance of Low-Flow and HighFlow Characteristics to Restoration of Riparian Vegetation Along Rivers in Arid South-Western United States. Freshwater Biology, 52, 651-679. https://doi.org/10.1111/j.1365-2427.2006.01713.x

Tague, C., \& Pohl-costello, M. (2020). The Potential Utility of Physically Based Hydrologic Modeling in Ungauged Urban Streams, 98(4), 818-833.

The City of San Diego, \& Geosyntec Consultants. (2018). Storm Water Standards. BMP Design Manual.

Trimble, S. W. (2003). Historical hydrographic and hydrologic changes in the San Diego creek watershed, Newport Bay, California. Journal of Historical Geography, 3, 422-444. https://doi.org/10.1006/jhge.2001.0485

U.S. Geological Survey, \& U.S. Department of the Interior. (2006). Estimating Magnitude and Frequency of Floods.

Vinodkumar, Dharssi, I., Bally, J., Steinle, P., McJannet, D., \& Walker, J. (2017). Comparison of Soil Wetness from Multiple Models Over Australia with Observations. Water Resources Research, 53, 633-646. https://doi.org/10.1002/2015WR017738.Received

Voynova, Y. G., Brix, H., Petersen, W., Weigelt-krenz, S., \& Scharfe, M. (2017). Extreme Flood Impact on Estuarine and Coastal Biogeochemistry: The 2013 Elbe Flood. Biogeosciences, 14, 541-557. https://doi.org/10.5194/bg-14-5412017

Walawender, M. J. (1999). The Penninslar Ranges: A Geological Guide to San 
Diego 's Back Country. Kendall Hunt Pub Co.

Wang, J., Zhang, Z., Greimann, B., \& Huang, V. (2018). Application and evaluation of the HEC-RAS - riparian vegetation simulation module to the Sacramento River. Ecological Modelling, 368, 158-168. https://doi.org/10.1016/j.ecolmodel.2017.11.011

Wen-ping, X. I. E., \& Jing-song, Y. (2013). Assessment of Soil Water Content in Field with Antecedent Precipitation Index and Groundwater Depth in the Yangtze River Estuary. Journal of Integrative Agriculture, 12(April), 711722. https://doi.org/10.1016/S2095-3119(13)60289-0

Weston Solutions Inc. (2009). Los Peñasquitos Lagoon TMDL - Watershed Phase I Sediment Source Identification Study Watershed Phase I Sediment Source Final Report. Retrieved from https://www.sandiego.gov/sites/default/files/lospensedimentstudy.pdf

Wheaton, J. M., Fryirs, K. A., Brierley, G., Bangen, S. G., Bouwes, N., \& O'Brien, G. (2015). Geomorphic mapping and taxonomy of fluvial landforms. Geomorphology, 248(November), 273-295. https://doi.org/10.1016/j.geomorph.2015.07.010

White, M. D., \& Greer, K. A. (2006). The Effects of Watershed Urbanization on the Stream Hydrology and Riparian Vegetation of Los Peñasquitos Creek, California. Landscape and Urban Planning, 74(2), 125-138.

https://doi.org/10.1016/j.landurbplan.2004.11.015

Zhao, Y., Wei, F., Yang, H., \& Jiang, Y. (2011). Discussion on Using Antecedent Precipitation Index to Supplement Relative Soil Moisture Data Series. Procedia Environmental Sciences, 10, 1489-1495. https://doi.org/10.1016/j.proenv.2011.09.237

Zou, X., Dai, Q., Wu, K., Yang, Q., \& Zhang, S. (2020). An Empirical Ensemble Rainfall Nowcasting Model Using Multi - Scaled Analogues. Natural Hazards, 103(1), 165-188. https://doi.org/10.1007/s11069-020-03964-3 


\section{CHAPTER 4: SUMMARY AND CONCLUSIONS}

\subsection{Summary and Conclusions}

Rivers are dynamic systems (Vinodkumar et al., 2017) that have long been studied through the lens of multiple disciplines because of their range of ecosystem services (Chatterjee, 2018; Fletcher et al., 2013). To better understand the impacts of stressors on these sensitive systems and ultimately how rivers can incur change, it is necessary to approach fluvial and hydrologic studies locally (Lecce, 1997; Walther, 2016) and holistically (Jarvie, Neal, \& Withers, 2006; Pietsch \& Nanson, 2011; Salvadore, Bronders, \& Batelaan, 2015). Establishing baseline data improves monitoring efficiency (Doran, 2016; Liu, Adam, \& Hamlet, 2013), and continued monitoring encourages adaptive management with considerations to changes in climate and urbanization (Walther, 2016).

In this thesis, I quantified morphologic variables, developed a method to combine large gravels and sievable sediment, screened for contaminants, developed a model to estimate runoff from precipitation, and modeled flows for five estimated flows. I found that slope differentiated the study area into an upper, middle, and lower reach which explained the reach-by-reach patterns exhibited by several other variables, including depth (D), velocity (V), and elevation (Z). Channel grain size (CGS) at 50\% in the cumulative grain size distribution (D50 values) decrease downstream and range from $0.25 \mathrm{~mm}-45 \mathrm{~m}$, bank D50 values are finer than channel values in the upper reach, after which the bank and channel values are less distinct. $\mathrm{D}$ is inversely related with $\mathrm{V}\left(\mathrm{R}^{2}=0.743\right)$ and $\mathrm{Z}\left(\mathrm{R}^{2}=\right.$ 0.884) and D, V, Z, D50s overall follow traditional downstream trends (Bierman 
\& Montgomery, 2020). Width (W) is most responsive to discharge (Q), confirming the findings of Pietsch \& Nanson (2011). W and CGS D50 are inversely related, supporting the results from Rengers \& Wohl (2007) and Walther (2016).

Grain size at LPC was spatially heterogeneous and did not have a strong correlation to metal concentrations, going against riverine sediment-metal findings by Marasinghe Wadige et al. (2016) and Phillips \& Slattery (2007). Metals and \%OC do not exhibit a longitudinal pattern at LPC. Few specific locations could use continued monitoring for specific metals, particularly $\mathrm{Cu}, \mathrm{Hg}$, and As, which often lined up (As) at or above ( $\mathrm{Cu}$ and $\mathrm{Hg}$ ) ERL limits. $\mathrm{Zn}, \mathrm{Pb}, \mathrm{As}$ were most correlated to \% OC supporting Marasinghe Wadige et al. (2016) \%OC was often also associated with qualitative observations of vegetation abundance in-channel and on banks. Phosphate increases within each reach but is not often above screening levels of $0.1 \mathrm{mg} / \mathrm{L}$ except at the confluence, $3 \mathrm{VC}$ and crossing near horse trails. Reach-by-reach patterns are also seen temperature, salinity, \& $\mathrm{pH}$.

Next, I determined a relationship between rainfall and runoff that uses a multiple regression empirical formula where API (5-day) and P (peak in a consecutive period) are independent variables used to estimate peak-flows. Rainfall is a highly variable measure when estimating runoff. Known recurrence intervals for LPC are as follows: RI-5=3,280, RI-10=4,670, RI-25=5,175, RI$50=5,730$, while estimated recurrence intervals are RI-5=2,899, RI-10=4,095, RI$25=5,675$, RI-50 $=6,870$, RI-100 $=8,066$, RI-500 $=10,841 \mathrm{cfs}$. The RI estimates 
were smaller for RI years 5 and 10, but larger for higher year intervals. The RCP estimates ranged from 7,908-8,246 cfs for 50-100 years, all higher than the RI estimated values. However, because estimates calculated from recurrence intervals use historic data, they do not reflect current and projected trends. Thus, RCP projections better include impacts from climate change in predicting flow.

Flow modeling for the RCP estimate discharge values of 7,908-8,246 cfs provide probable flood inundation and width extent. Locations most at risk for flooding under high-flow scenarios are the baseball park and directly west (by Ranch House Crossing) and the area south of Peñasquitos Creek Crossing, especially for flows $>4,095$ cfs. Carson's Crossing will experience strong flows and continued annual crossing damages because of impounding due to canyon constriction directly upstream. The data show that that metals at Carson's Crossing (5SA) and Ranch House Crossing (4CA) increase with distance from the channel center. Specifically, $\mathrm{Zn}, \mathrm{Cu}, \mathrm{Pb}$ increase in concentration, especially towards the right bank. This may be attributed to a combination of a physiochemical rich environment, \%OC, finer grain sizes with increasing width, and proximity to development.

The first two questions of this study contribute to acquiring data for Los Peñasquitos Creek at a localized longitudinal scale for comparison against future measurements, as well as suggest monitoring sites for future sampling. These data include morphologic characteristics, grain size, metals, phosphate, \%OC and the overall connectivity between these variables along with a qualitative assessment of local influences (riparian zone, urbanization, horse and hiker traffic, etc.). 
Additionally, we gathered samples at the lagoon to determine what influence the creek is having on metal and nutrient input into the lagoon. The last two questions of this study attempt to inform management on specific crossings or areas along the upper/middle preserve to create retention areas and longer crossings. To reduce expenses incurred from regular preserve maintenance, these data overall provide focus areas for monitoring, as well as planning for increased frequency of high-flows.

\subsection{Future Work and Closing Remarks}

Based on the findings from this research, recommendations for future studies conducted at Los Peñasquitos Creek and Peñasquitos sub watershed should address several broad topics. These include sediment accretion throughout the creek: determining major sources, relationship with riparian zone, and output to the south side of the lagoon. Continue monitoring for trace metals in recommended localized areas and test for bioavailability and mobility of $\mathrm{Hg}$, $\mathrm{As}$, $\mathrm{Cu}$, and $\mathrm{Pb}$ at Chicarita Creek $(1 \mathrm{CH})$, near Ranch House Crossing (4CA) or Peñasquitos Creek Crossing (5SA), and Wagon Wheel Crossing (7PB). Nutrient studies every few years at the confluence and preserve horse trail crossings, 3VC, 4CA, 5SA could be helpful for insights to potential eutrophication. We recommend estimating runoff every 5 years using precipitation and land-use change to better estimate future flows by incorporating future land-use change and storm drain installation within Peñasquitos sub watershed. Future flows can also be used to model fluvial processes, material (contaminant) mobilization, and 
riparian zone change. Finally, these methods can be applied to future studies on Carmel Creek and Carroll Canyon Creek tributaries.

This study emphasizes the urgency of comprehensive projects that consider morphology and changes to hydrology at a local scale. This is critical in small, coastal, densely-populated watersheds in semi-arid and arid climates because they are at risk for exacerbated drought-storm cycles in a changing climate. These small creeks in dry climates are often ignored because of the high evaporation and ephemeral or limited flow for most of the year, yet the ecosystem is, in fact, more sensitive to changes in runoff (Bekhira, Habi, \& Morsli, 2019). These creeks flow through small watersheds with limited open-space and funding: it is imperative to acknowledge their ecosystem services, address risks to the specific watershed, identify solutions, and help improve management of these unique, ecologically, culturally, and economically important spaces. 


\subsection{References}

Bekhira, A., Habi, M., \& Morsli, B. (2019). Management of Hazard of Flooding in Arid Region Urban Agglomeration Using HEC-RAS and GIS Software: The Case of the Bechar's City. Journal of Water and Land Development, 42(7-9), 21-32. https://doi.org/10.2478/jwld-2019-0041

Bierman, P. R., \& Montgomery, D. R. (2020). Drainage Basins. In Key Concepts in Geomorphology (2nd ed., pp. 239-270). New York: MacMillan Learning.

Cesar, R., Egler, S., Polivanov, H., Castilhos, Z., \& Rodrigues, A. P. (2011). Mercury, Copper and Zinc Contamination in Soils and Fluvial Sediments From an Abandoned Gold Mining Area in Southern Minas Gerais State, Brazil. Environmental Earth Sciences, 64(1), 211-222. https://doi.org/10.1007/s12665-010-0840-8

Doran, C. (2016). Land Use and Its Relationship to Riparian Zone Organic Carbon Storage on the Upper Hunter River. University of Wollongong.

Jarvie, H. P., Neal, C., \& Withers, P. J. A. (2006). Sewage-Effluent Phosphorus: A Greater Risk to River Eutrophication Than Agricultural Phosphorus? Science of the Total Environment, 360, 246-253. https://doi.org/10.1016/j.scitotenv.2005.08.038

Lecce, S. A. (1997). Nonlinear Downstream Changes in Stream Power on Wisconsin's Blue River. Association of American Geographers, 87(3), 471486.

Liu, M., Adam, J. C., \& Hamlet, A. F. (2013). Spatial-Temporal Variations of Evapotranspiration and Runoff/ Precipitation Ratios Responding to the Changing Climate in the Pacific Northwest During 1921-2006. Journal of Geophysical Research Atmospheres, 118(2), 380-394. https://doi.org/10.1029/2012JD018400

Marasinghe Wadige, C. P. M., Taylor, A. M., Krikowa, F., \& Maher, W. A. (2016). Sediment Metal Concentration Survey Along the Mine-Affected Molonglo River, NSW, Australia. Archives of Environmental Contamination and Toxicology, 70(3), 572-582. https://doi.org/10.1007/s00244-015-0259-z

Phillips, J. D., \& Slattery, M. C. (2007). Downstream Trends in Discharge, Slope, and Stream Power in a Lower Coastal Plain River, 290-303.

https://doi.org/10.1016/j.jhydrol.2006.10.018

Pietsch, T. J., \& Nanson, G. C. (2011). Geomorphology Bankfull Hydraulic Geometry; The Role of In-Channel Vegetation and Downstream Declining Discharges in the Anabranching and Distributary Channels of the Gwydir Distributive Fluvial System, Southeastern Australia. Geomorphology, 129(12), 152-165. https://doi.org/10.1016/j.geomorph.2011.01.021

Rengers, F., \& Wohl, E. (2007). Trends of Grain Sizes on Gravel Bars in the Rio Chagres, Panama. Geomorphology, 83, 282-293. https://doi.org/10.1016/j.geomorph.2006.02.019

Salvadore, E., Bronders, J., \& Batelaan, O. (2015). Hydrological Modelling of Urbanized Catchments: A Review and Future Directions. Journal of Hydrology, 529(P1), 62-81. https://doi.org/10.1016/j.jhydrol.2015.06.028

Walther, S. C. (2016). Environmental Flow Development: Geomorphic Considerations from the McKenzie River, Oregon. Yearbook of the 
Association of Pacific Coast Geographers, 78, 94-119. https://doi.org/10.1353/pcg.2016.0007 


\section{APPENDIX A: Site descriptions}

\section{CH: Chicarita Creek}

$1 \mathrm{CH}$ is the tributary sample site, located south of Black Mountain and north of 2SB. It feeds under a couple of local bridges into the confluence at $3 \mathrm{VC}$. There are residential developments farther from the left bank and business buildings on the right bank. Chicarita creek appears sinuous from aerial view and on-site but is curved because of the geography of the canyon. The channel sits at a higher elevation than the other sites and lies between two steep upward slopes on either bank. This site is part of the Santiago Peak Volcanics, where there are larger rocks, unconsolidated throughout the creek. There may be some added gravels. The sediment ranges from sand at point bars to embedded boulders in the channel. There are high cut banks carved by water and a few riffle-pool-riffle present. Larger cobbles lie in the riffles slightly upstream in the meander. Vegetation includes large trees, chaparral, tangled roots and branches up the carved banks, several reeds, and grass on the left bank. There are some floral plants on both banks and not much algae compared to other sites.

Field measurements and sampling information (06/20/2019),

Qgage: $1.91 \pm 0.09 \mathrm{GH}: 2.86 \pm 0.01$

One cross section was surveyed at $\mathrm{CH}$. The cross-section was $16 \mathrm{~m}$, with the channel width being separated by a small vegetated island. The channel was $2.55 \mathrm{~m}$ to the left of the island and $2.1 \mathrm{~m}$ to the right, where velocity was greater. The total width of the channel slightly upstream or downstream the island was around $6 \mathrm{~m}$. A total of four water samples and eight sediment samples were collected (three in-channel), and a gravel count slightly upstream the cross section surveyed. The highwater mark was $1.6 \mathrm{~m}$ on the left bank. The right bank has a sharp bend and is scoured out several meters.
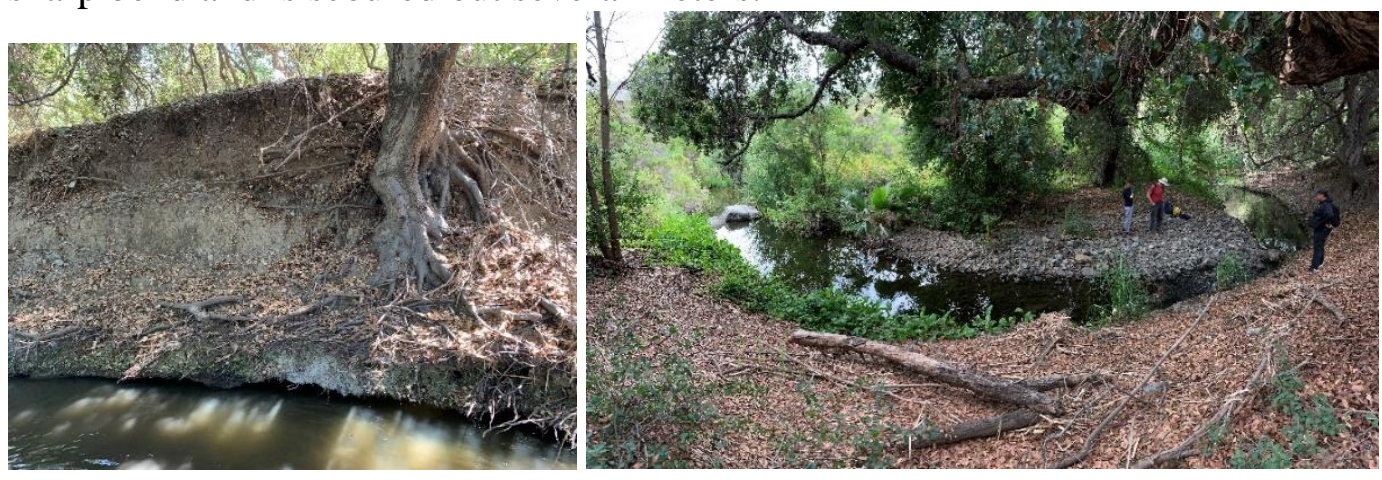

\section{SB: Springbrook}

The farthest upstream site, 2SB was surveyed across the multiple channels formed here. The site is on Friar's formation with some granites, gabbro, cyanite, and tonalites. It is not on the preserve and instead lies alongside dense residential developments. Less than $1 / 3$ kilometer from the left bank, with a gentler slope (elevation increase $6 \mathrm{~m}$ ), lies a neighborhood and a trail. Farther upstream on left 
bank is another neighborhood. Within $0.8 \mathrm{~km}$ from right bank is a large development. The right bank slopes higher with an elevation increase of about 15 $\mathrm{m}$. Entering the channel from left bank, downstream an overhead bridge, there is a steep drop off into a dry cobble-embedded channel. The drop-off is evidence of a wet-season well-eroded bank. Downstream of the dry channel is a scour pool. The sediment overall ranges from sand to large cobbles. Deposition embeds mostly the right bank. Sediment also looked unconsolidated, except at the bottom of the riffle and farther towards right bank. Under the cobbles was sand-sized sediment. Of the four channels created at this site, the main flow comes from the second channel. The two cobble-bedded channels closer to right bank are mostly dry with no flow. Between Channel 2 and 3 are palm trees that would not naturally be found in this riparian zone and have likely washed into the canyon from landscaping in the surrounding residential areas. There is denser tree vegetation that impacted accessibility and right-channel algae. Dense vegetation was not expected here but may also be influenced by water and nutrient input related to residential urbanization.

Field measurements and sampling information (06/20/2019)

Qgage: $1.91 \pm 0.09 \mathrm{GH}: 2.86 \pm 0.01$

One $30 \mathrm{~m}$ cross section was surveyed. Of the four channels that formed, the main channel width was $\sim 3 \mathrm{~m}$ with two velocities measured. A total of four water samples and eight sediment samples (five in-channel) were collected, in addition to gravel grab samples. The high-water mark was $0.26 \mathrm{~m}$.

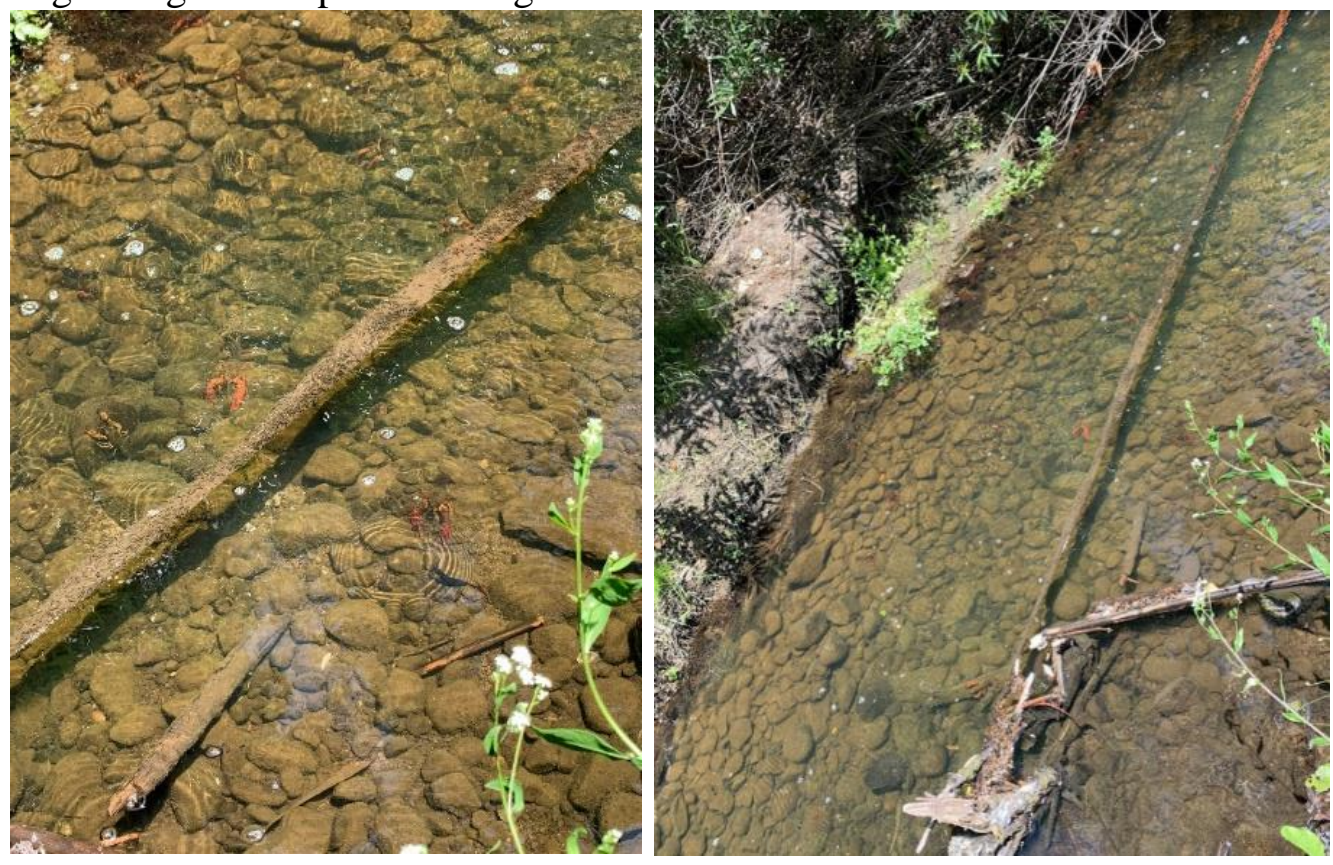

\section{VC: Via Cabezon}

$3 \mathrm{VC}$ is upstream from the preserve and the confluence for the main channel and tributary. The channel lies between an upper sloped canyon on the 
left bank and a large residential neighborhood 1/3 kilometer from the right bank. The canyon is narrower at VC than sites downstream. In addition to narrowed geography, several storm drains are located near the right bank of the site contributing to higher flow. A concrete road goes through the channel connecting the right and left bank. The road acts like a 'run-of-river' dam where water back up behind it where erosion has formed a pool and pours over it differently due to its smoothed impervious surface. Upstream of the crossing is more natural, whereas downstream is anthropogenically influenced from increased flow velocity and added riprap, both rocks and concrete. The added riprap also gets eroded and contributes to the localized downstream environment. There are riffles naturally occurring upstream. Downstream there is also a riffle-pool because of the added riprap. The water falls immediately after the concrete path. Both banks have still-water and most of the flow is central. Vegetation is the reason for the still water and small side streams. The channel banks are teeming with sedges. Toppled over sedges close to the banks, are evidence of higher flow. Downstream, past the cross section, cobbles are covered with both brown and green algae, floating and laying over the rocks/concrete. Possibly due to more sun exposure and less tree coverage, and/or nutrient input from urbanization and lower $\mathrm{pH}$.

Field measurements and sampling information (06/14/2019)

Q gage: $1.96 \pm 0.14 \mathrm{GH}: 2.87 \pm 0.02$

Two $36 \mathrm{~m}$ cross sections were surveyed. Channel width at the cross sections were about $6-8 \mathrm{~m}$ and widened in the downstream pool. A total of seven water samples and eight sediment samples (five in-channel) were collected. Four velocities were measured at each cross section and discharges for the upper cross-section were used for statistical purposes. The highwater mark was recorded at $2.5 \mathrm{~m}$ at both banks.
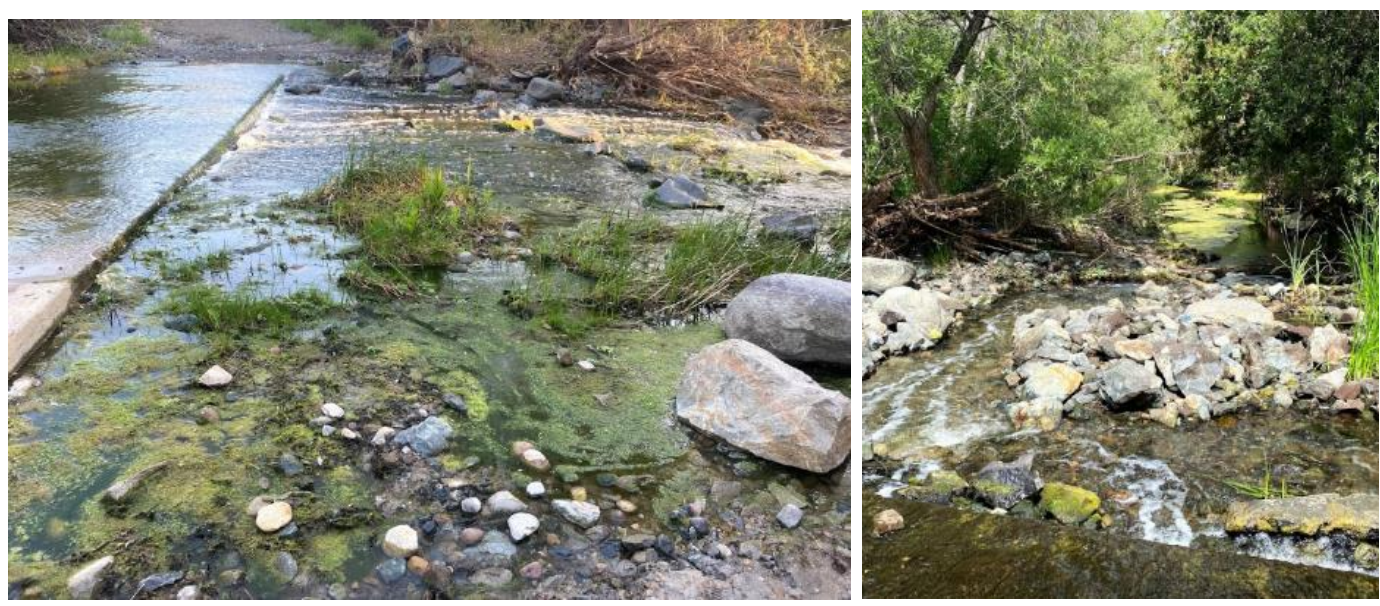

4CA: Canyonside

4CA is one of the research sites on the preserve (near Ranch House Crossing) and is closest to the upstream confluence. Two cross sections were surveyed, in part due to accessibility but also to capture the variation in pool-riffle 
local geography at this site (CA-1 and CA-2, respectively). Three channels form at CA-1, the right bank drops into the first and only flowing channel. Farther into the right bank is a scour pool from overflow. The next three channels toward left bank are dry and form banks between each other. The slope is flatter here than at the upstream sites and could be what causes the channel to spread out, creating the wider floodplain. There is very little flow in the primary channel, causing finer sediment to settle. Sediment ranges from silt to gravel in the dry channels. Sediment is tangled with organic matter from the dense tree vegetation and bank erosion. As CA-1 flows downstream under a toe-bridge into CA-2, the main channel only slightly widens but multiple channels are not seen. This could be because vegetation is too dense to access the full floodplain or because the poolriffle system funnels the flow. Gravels and cobbles are in this channel with finer sediment underneath. After the bridge, a tree stands on a vegetated island. Flow comes from either side of the island. Left bank is tangled with vegetation and there is slower flow. The flow from the right of the vegetated island contributes to faster flow and the riffle. There are no urbanized residential areas directly near this site. A community park is $<0.32 \mathrm{~km}$ away from the right bank. Since the site is on the preserve, it is a heavily trafficked area with hikers, bikers, camps, and horse-back riders.

Field measurements and sampling information (06/18/2019) Qgage: $2.25 \pm 0.07 \mathrm{GH}: 2.91 \pm 0.01$

CA1: The full cross section length was $43 \mathrm{~m}$, the channel width was $7.5 \mathrm{~m}$. CA2: Only a partial cross section length was possible at this site due to dense vegetation and accessibility. The channel width was $6.2 \mathrm{~m}$.

A total of five water samples and nine sediment samples (four in-channel) were collected, with a gravel count was done at CA2. CA1 had two velocity measurements while CA2 had four, due to variation of flow. Discharge was calculated separately for both but discharge for CA2 is used for all research purposes.

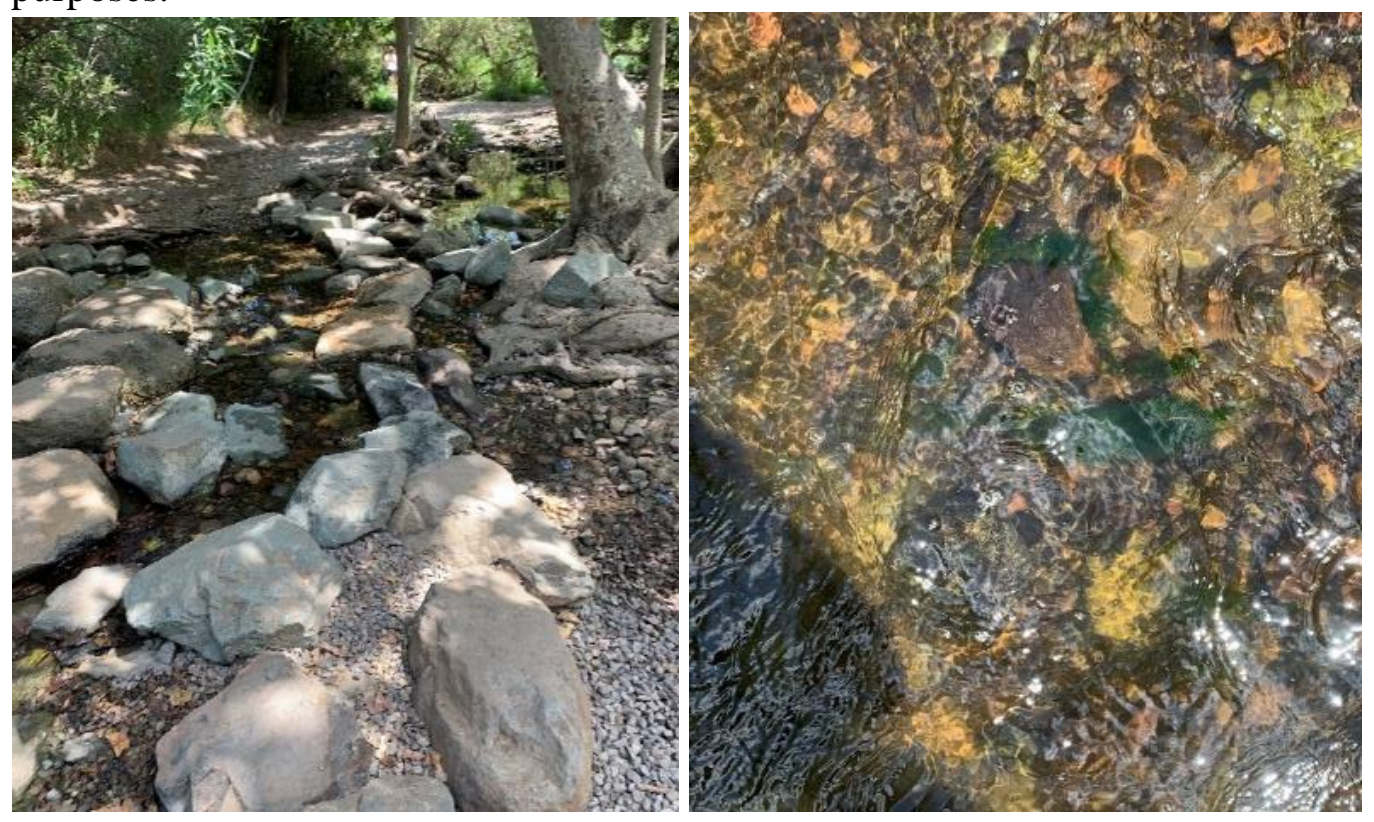




\section{SA: Salix Way}

5SA is also on the preserve (Carson's Crossing). It is also upstream to the waterfall. One cross section was surveyed at this site due to vegetation and access limitations. Within this single cross section, there are five channels. The channel closest to the right bank is deepest, as we progress to left bank, there is pooling, and then a slow flow second channel. Vegetation follows, and then a third cobblebedded fast flow channel. There is again vegetation, and then a back channel, dried out, followed by vegetation, and then a small riffle pool, medium flow channel. After the fifth channel is a sixth dried out sandy-bottomed back channel. The sediment ranges from clay to cobbles. Cobbles are mostly found in the $3^{\text {rd }}$ channel, with some cobble deposits in the $4^{\text {th }}$ and $5^{\text {th }}$ channel. The $1^{\text {st }}$ and $2^{\text {nd }}$ channels are mostly silty sand and some clay(?). Left bank has a horse trail. Vegetation between every channel includes poison oak, trees, invasive palm trees (carried from yards in local neighborhoods), Some flower bushes lie downstream, algae is present in channel 4 and algae covered cobbles are seen in channel 3. Each channel has reeds along the edges. Less than 1/3 kilometer from right bank is a residential development. This may be contributing to drainage and invasive palms.

Field measurements and sampling information (06/13/2019):

Q gage: $1.98 \pm 0.07 \mathrm{GH}: 2.87 \pm 0.01$

A single cross section was taken. The auto-level $(119.2 \mathrm{~cm})$ was set at left bank and went to a segment width of $50 \mathrm{~m}$. A GPS point was taken $7 \mathrm{~m}$ from the Auto level, at the trail point. The HW at right bank, around $50 \mathrm{~m} \mathrm{SW}$ was around 33 $\mathrm{cm}$. The second right bank $\mathrm{HW}$ was recorded at $48 \mathrm{~m} \mathrm{SW}$ and approximately 46 $\mathrm{cm}$. The three left bank HW marks was $69 \mathrm{~cm}, 69 \mathrm{~cm}$, and $78 \mathrm{~cm}$ at $6 \mathrm{~m} \mathrm{SW}$, downstream. Nine water samples and seventeen sediment samples (thirteen inchannel) and a gravel grab sample was taken in Channel 3. A total of eight velocities were taken, with at least one measurement per channel. Although each channel was separated by bank, a total discharge was calculated for the site since they all merge.
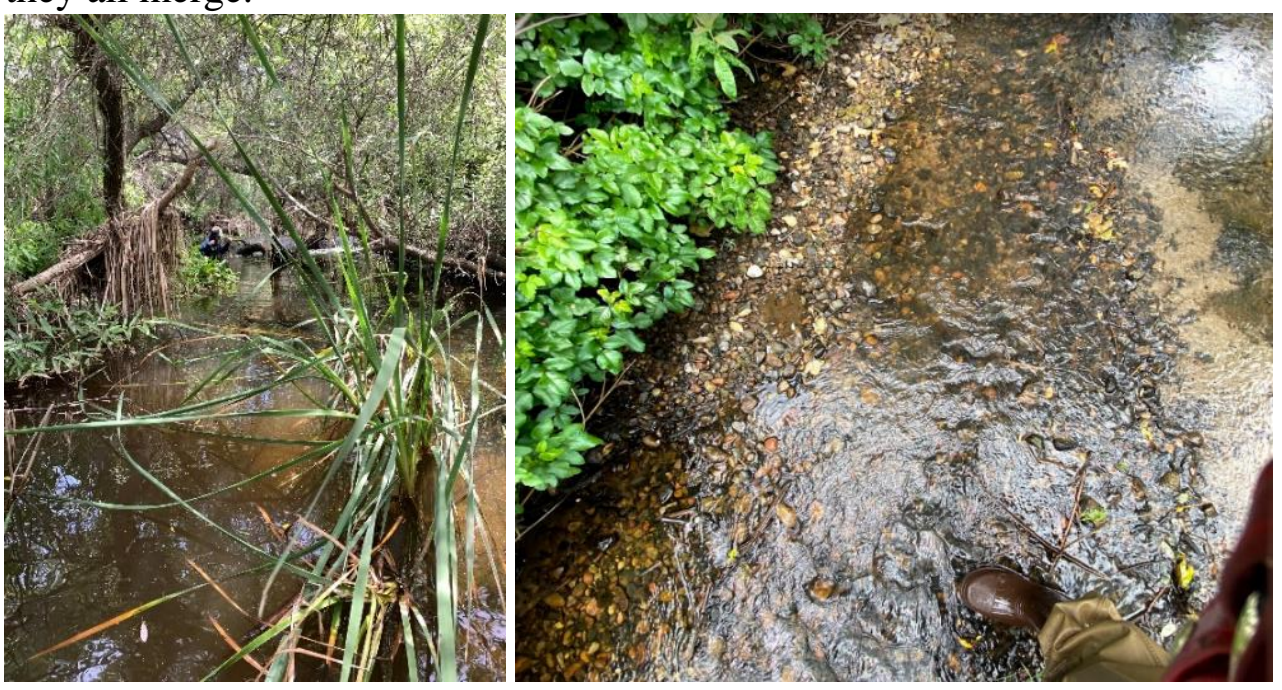


\section{SY: Sycamore Crossing}

$6 \mathrm{SY}$ is located on the south side of the Los Peñasquitos preserve and owned by the city. It is located before the I-5 bridge, approximately $2 \mathrm{~km}$ upstream from Wagon Wheel Crossing. Though the urbanization is similar to that of Wagon Wheel Crossing, Sycamore Crossing is unique because it is directly intersected by a horse trail and possibly exposed to coliform. There are also walking trails near and around this crossing and may have influence from hikers. The vegetation includes reeds, sedges, dense tree canopies, and chaparral. Reeds are more abundant downstream the bridge. The area is characterized as the Peñasquitos formation and Jurassic formation passed the waterfall. There are two dried back channels near the left bank that has cobble deposits. There is a small island in the central area of the channel, where mounds of sand have been deposited to the right side of the island and there is more sand accretion on the right bank. Water's edge was not recorded for the dried back channels. Most of the flow channelizes between 9-22 $\mathrm{m}$ despite the width, there is a vegetated island, but water goes around.

Field measurements and sampling information (06/21/2019):

Qgage: $2.21 \pm 0.2 \mathrm{GH}: 2.90 \pm 0.03$

One cross section was taken at $6 \mathrm{SY}$ due to survey limitations. A transect tape and Auto-level $(94.5 \mathrm{~cm})$ was set at left bank and reached $62 \mathrm{~m}$ to right bank. The GPS location was taken outside the cross section, at the 76 and $75 \mathrm{~m}$ mark (14 m, and $13 \mathrm{~m}$ farther right bank from the transect tape). There was a mini island, sand mound that went up to the $13.6 \mathrm{~m}$ mark farther downstream, before the bridge. Most of the flow was between the 16-17 $\mathrm{m}$ where there is a bridge. There is a small riffle upstream, the bridge, and then reeds downstream. Though the water's edge was recorded at $22 \mathrm{~m}$, the water goes around, but the flow funnels under the bridge. Sedges are right of the riffle, and two dry back channels follow.

Downstream of the sedges is the island and sand accretion is piled beyond the island. A trail leads from the $62 \mathrm{~m}$ segment width to beyond the sand dune. High water mark was taken $1.89 \mathrm{~m}$ from $11.5 \mathrm{~m} \mathrm{SW}$, elevation was recorded at $2.12 \mathrm{~m}$. Another high-water mark was taken $1.06 \mathrm{~m}$ from $21.5 \mathrm{~m} \mathrm{SW}$, with an elevation of $1.4 \mathrm{~m}$. Channel width was $12.8 \mathrm{~m}$ and a backwater channel $8.1 \mathrm{~m}$. Four water samples and nine sediment samples (four in channel) were collected. Three velocity measurements were taken in the main channel.

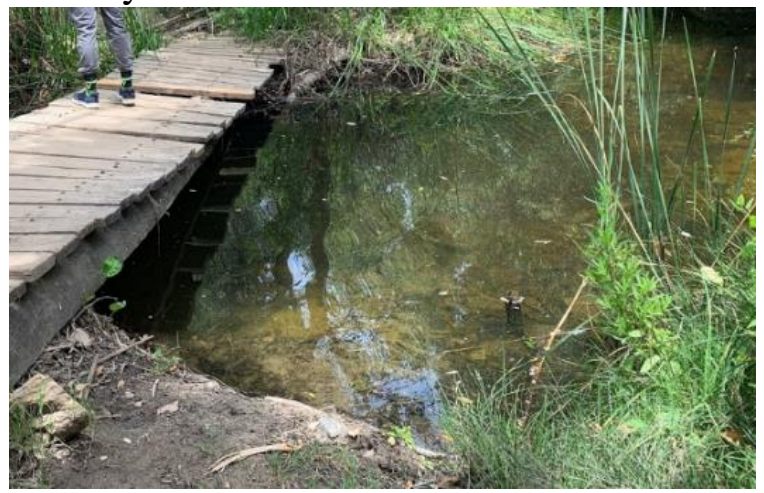




\section{PB: Wagon Wheel Crossing}

7PB on the south side of Los Peñasquitos preserve. This area is owned by the City. The site is located before the I- 5 bridge where there are taller trees. There is no development on the immediate south side. On the north side, there is a single-family home residential community at the canyon top. Downstream there are some biotech companies. The vegetation is characterized by reeds, grasses, trees, dry shrubs, and vines. There is no vegetation in the channel except the reeds. Biota also includes crayfish and small nail-sized fish. Geology and sediment include larger rocks on the left and right banks. Some larger jagged rocks are in the stream. Past the bridge, there are some grasses followed by small, somewhat smooth jagged rocks. Some larger rocks potentially blocking deposition. Where the grass is, on the left bank, there is finer clay/silt sized sediment deposition. The newly deposited sediment attaches onto the vegetation on the bank, and the organic decay also contributes to the finer sediment.

Field measurements and sampling information: (06/12/2019)

$Q_{\text {gage: }} 2.03 \pm 0.17 \mathrm{GH}: 2.88 \pm 0.02$

A transect tape and Auto-level $(112 \mathrm{~cm})$ was set at the left bank and reached $35 \mathrm{~m}$ to the right bank. The first transect is PB_3 which was $2.85 \mathrm{~m}$ downstream of PB_2 (at downstream edge of bridge) and $4.95 \mathrm{~m}$ downstream of PB_1 (at upstream edge of bridge). The YSI reading was taken, center channel, at PB_2. PB_1 was approximately $30 \mathrm{~m}$. GPS and auto-level/stadia points were taken fully at PB_1 and PB_3. A total of nine water samples and thirteen sediment samples were collected (ten in-channel). Three velocities were recorded for each cross section, nine in total. Discharge was calculated for the first cross section since it had the least anthropogenic disturbance.
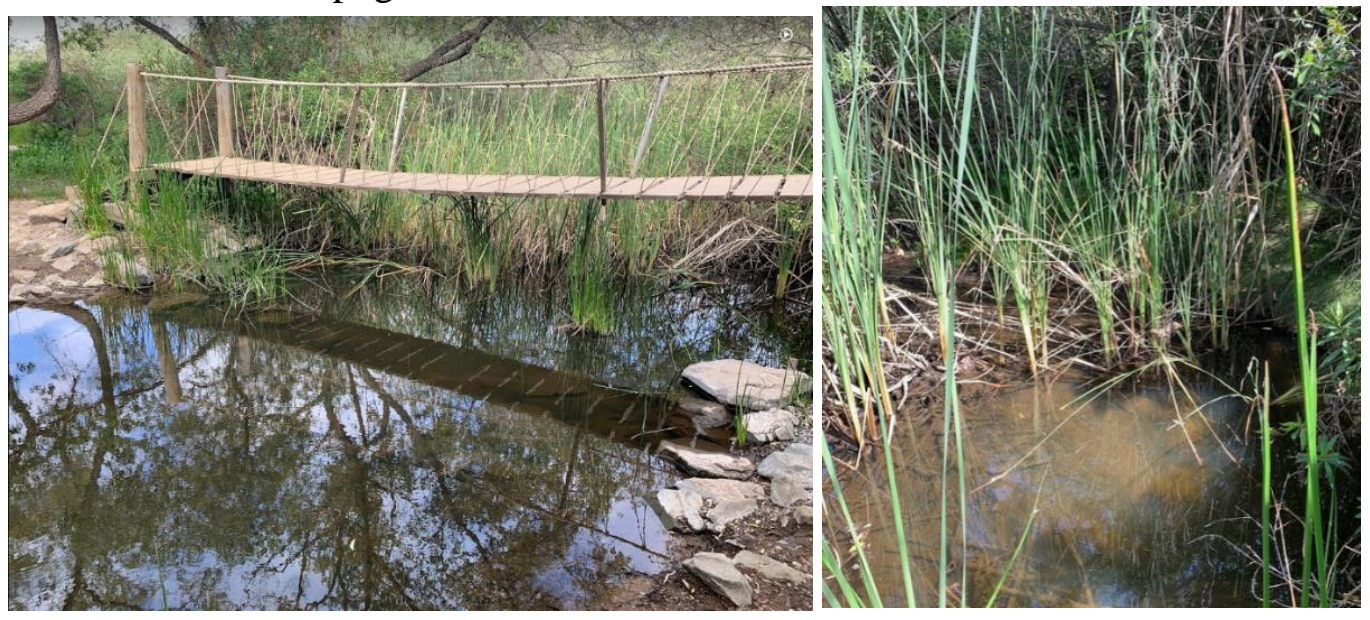

\section{LPL: Los Peñasquitos Lagoon}

The lagoon sites are all located on what is referred to as the 'South Side' of the lagoon. These sites were chosen based on concurrent graduate research. There are three sub-sites. 8LPL-a: Located farthest east closest to the estuary, next to train tracks. This site is not very well shaded, is grassy short chapparal, 
and flow is typically fast, shallow, and fresh. The flow depends on the tide. During low tide, flow is more turbulent and during high or normal tide there is quick flow, but not turbulent or laminar. Gravels are about $4 \mathrm{~mm}$ or less and the channel width is about 1 meter. 8LPL-b: Located closest to the public hiking trail and is characterized with larger bushes and pickleweed. The channel is about 2-3 $\mathrm{m}$ wide and about $1.2 \mathrm{~m}$ deep, deeper than site a. Larger bushes and pickleweed. 8LPL-c: Located closest to the mouth of the estuary on the east side. Water comes in from the ocean but calms down when it goes to the side channel. This site contains an oyster reef. The reason for the oysters occupying this location is not well-known but are brought by the ocean and settle when the water settles. While these oysters are invasive, only the shells exist in the reef. This provides a good habitat for the fish by providing shelter. They also slow the water by acting as biological roughness. This site is most exposed to tidal changes. It is also mostly saltwater unless there is a rainfall event, bringing the freshwater to about 8 ppt.
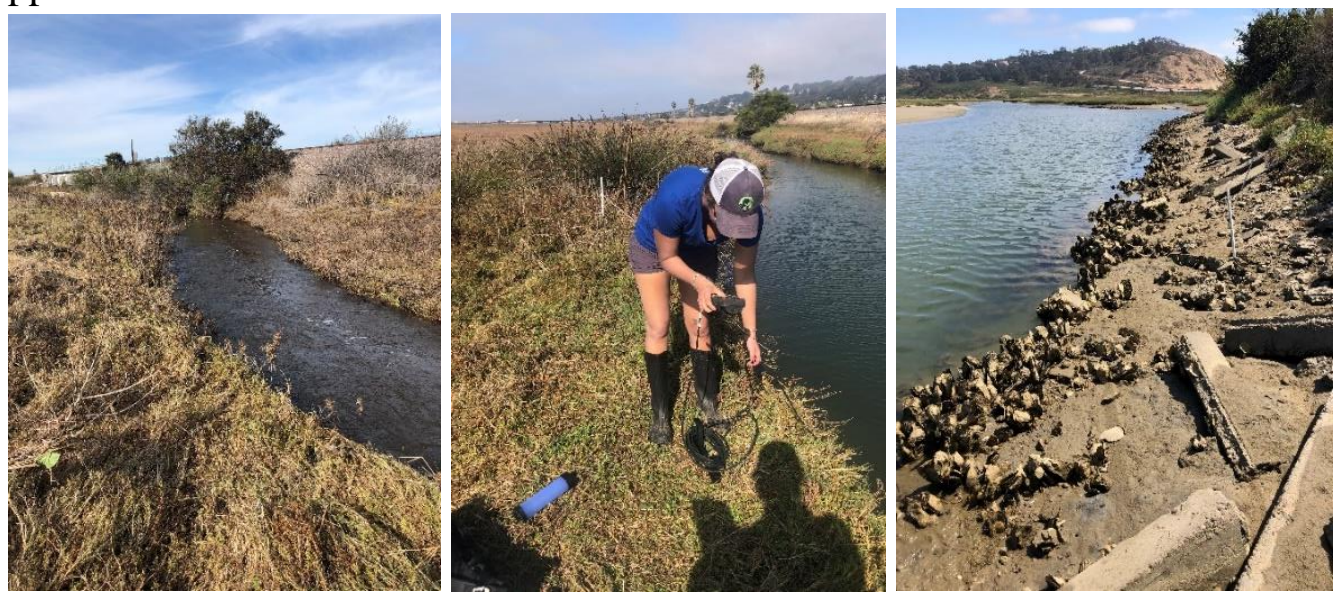

c 
Width (m)

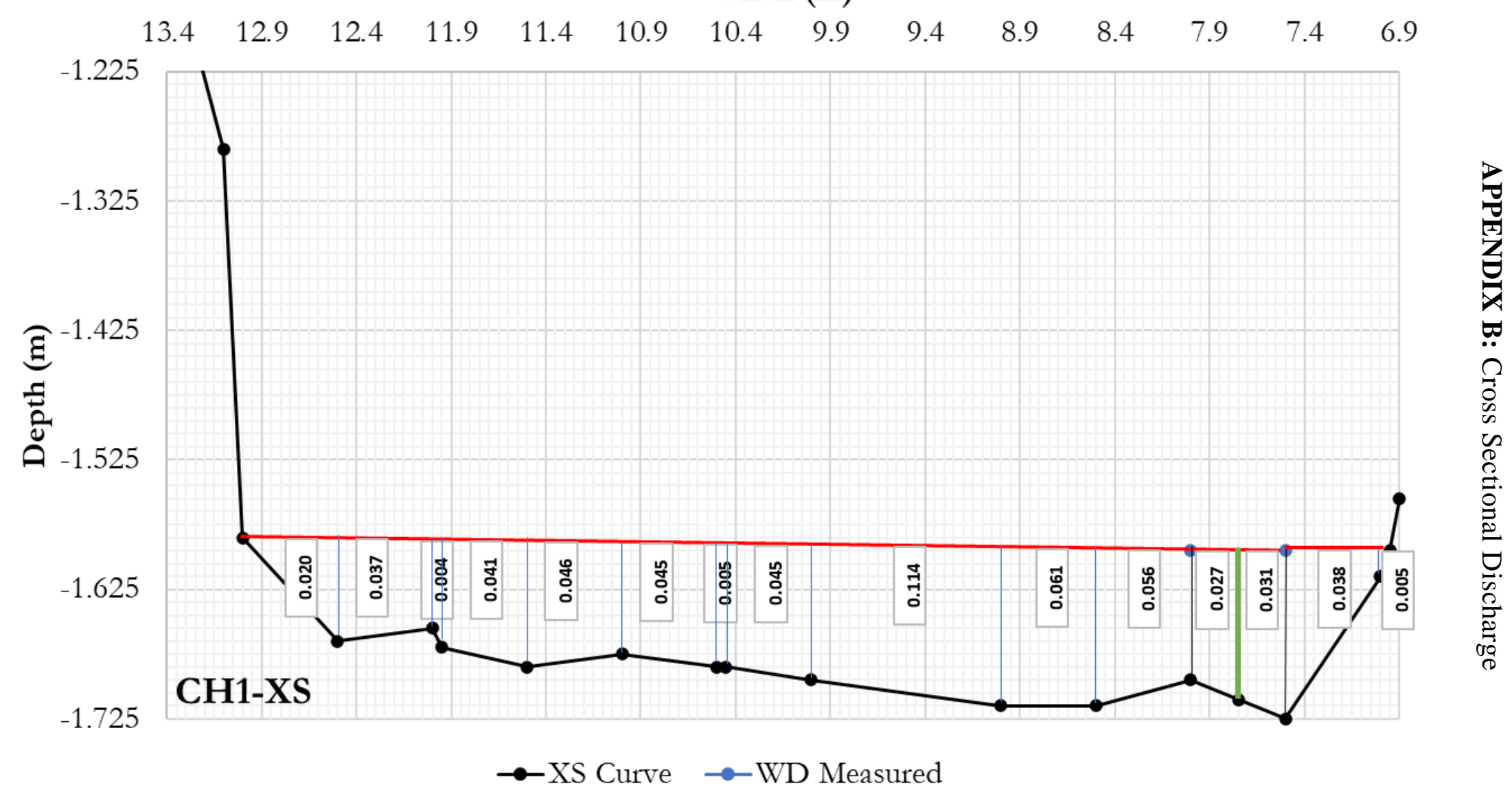




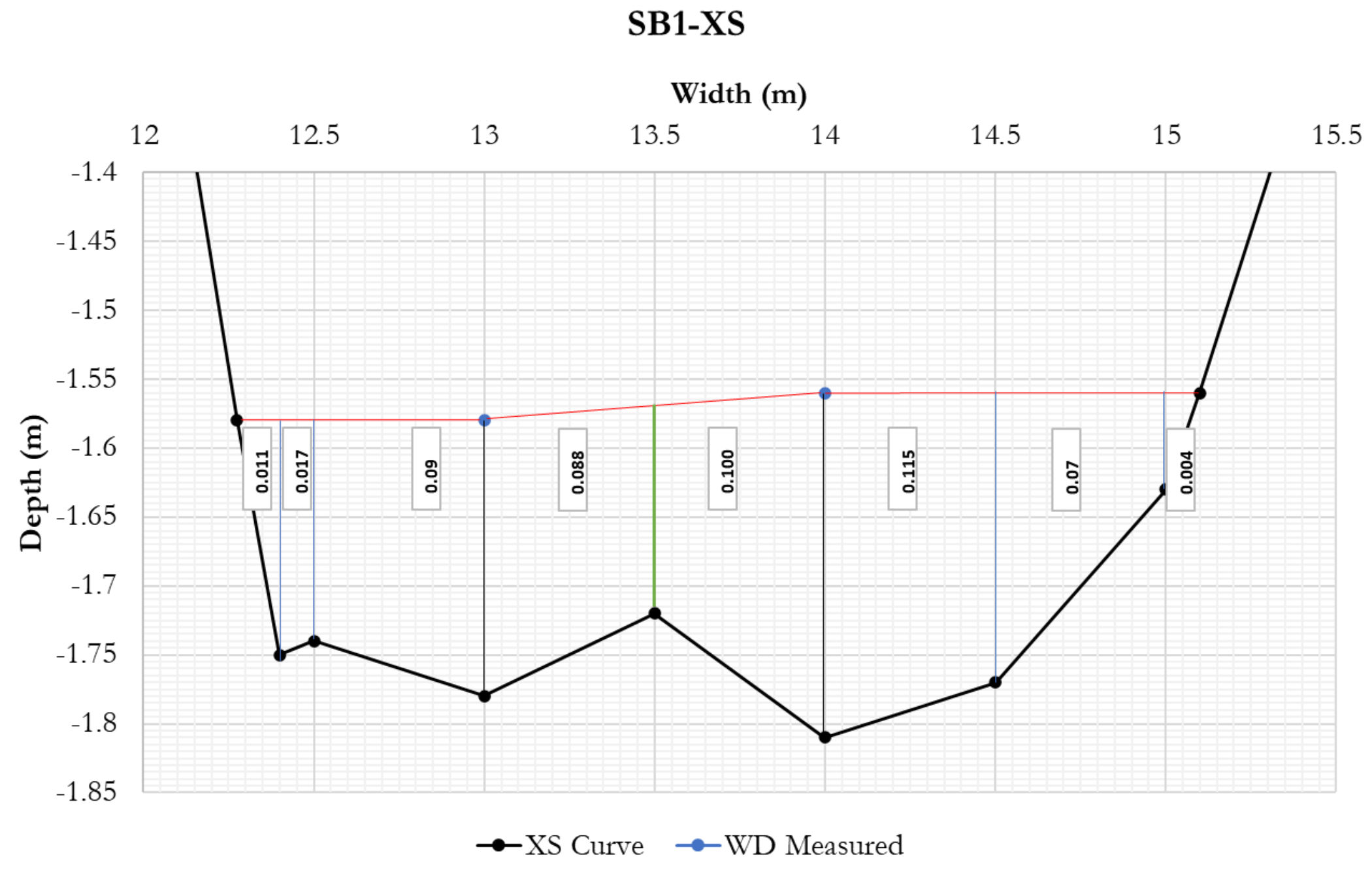




\section{VC1-XS}

\section{Width (m)}

$\begin{array}{lllllllllllllllllllllll}11 & 11.5 & 12 & 12.5 & 13 & 13.5 & 14 & 14.5 & 15 & 15.5 & 16 & 16.5 & 17 & 17.5 & 18 & 18.5 & 19 & 19.5 & 20 & 20.5 & 21 & 21.5 & 22\end{array}$

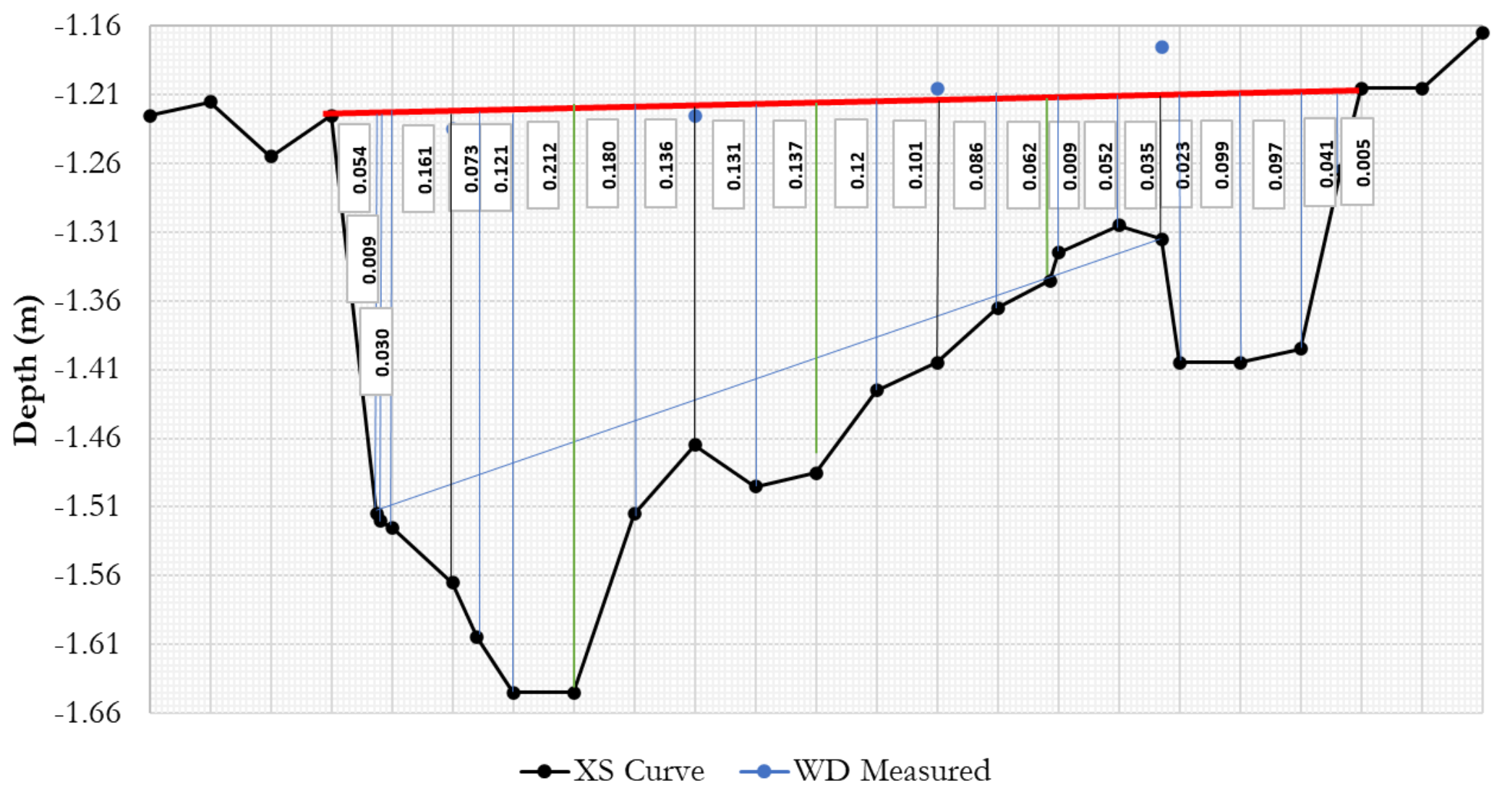




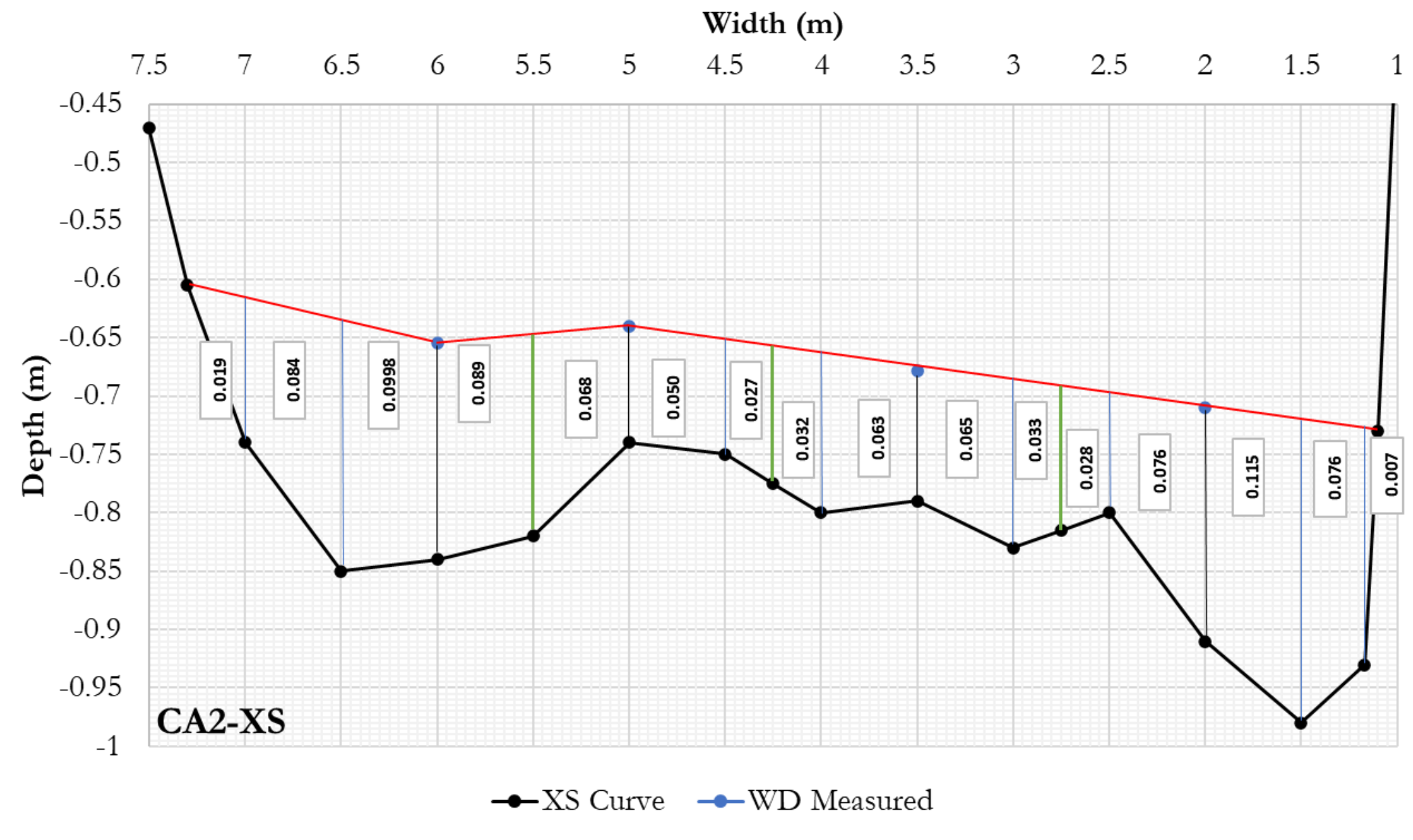




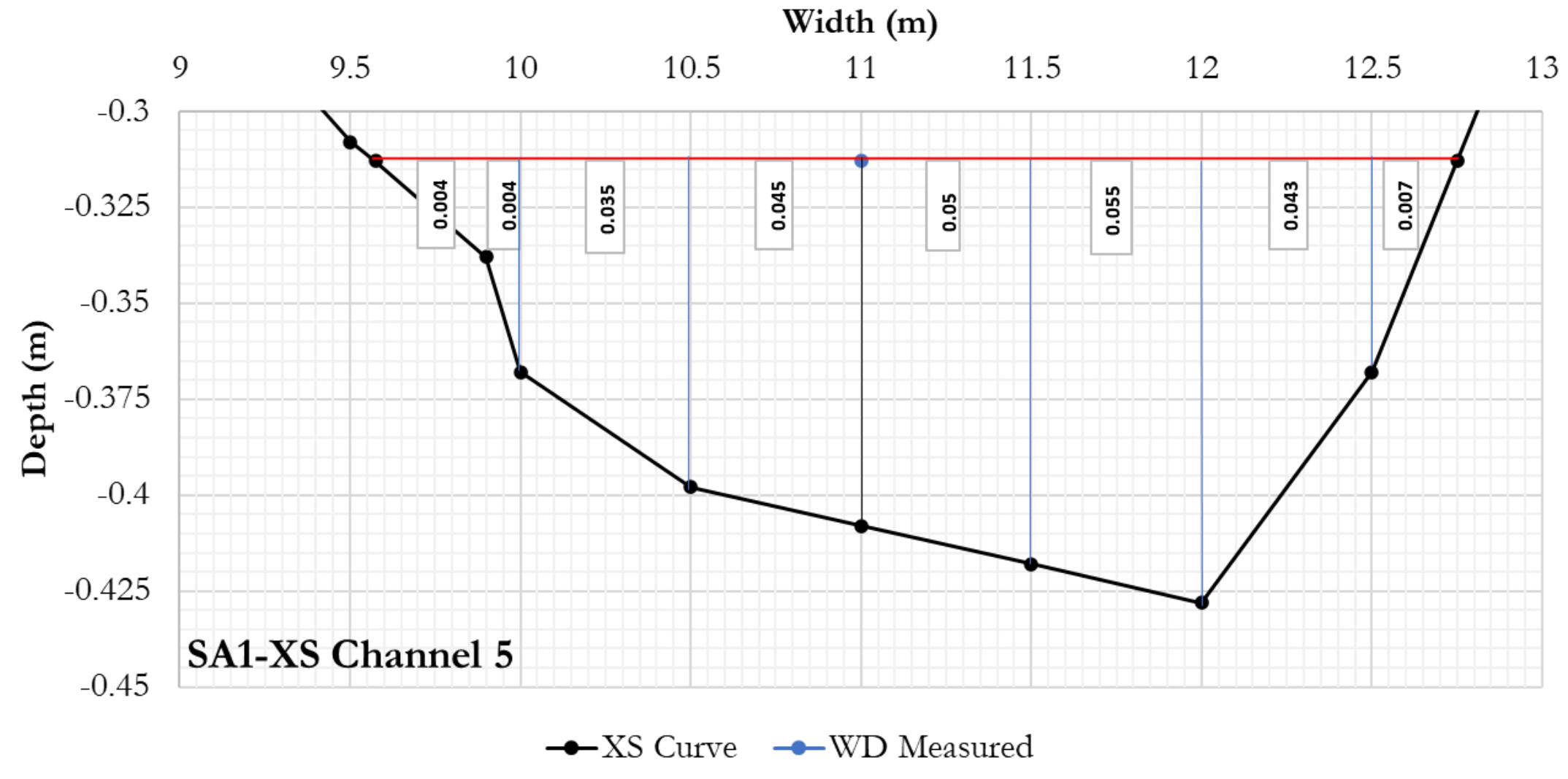

$\vec{q}$ 


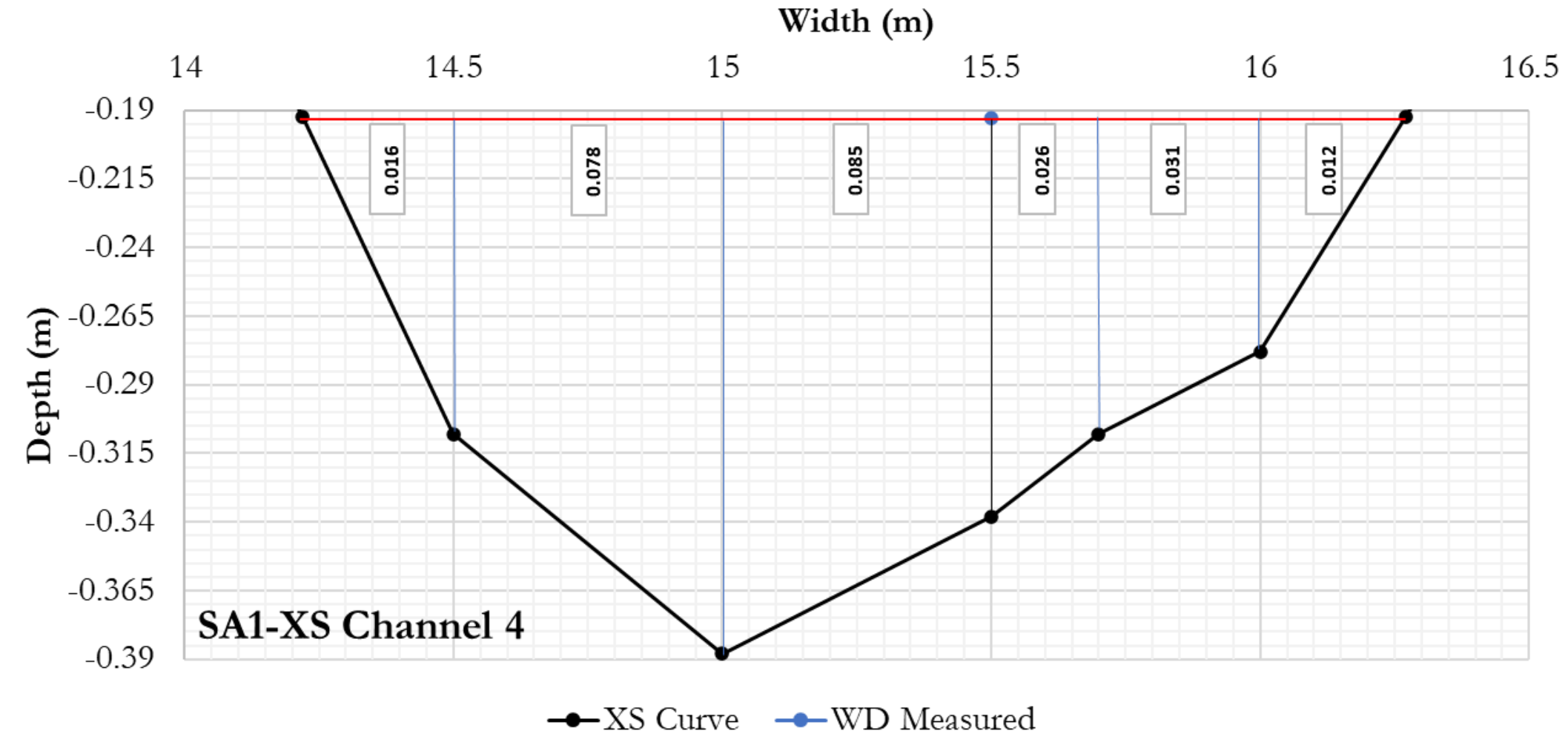

o 


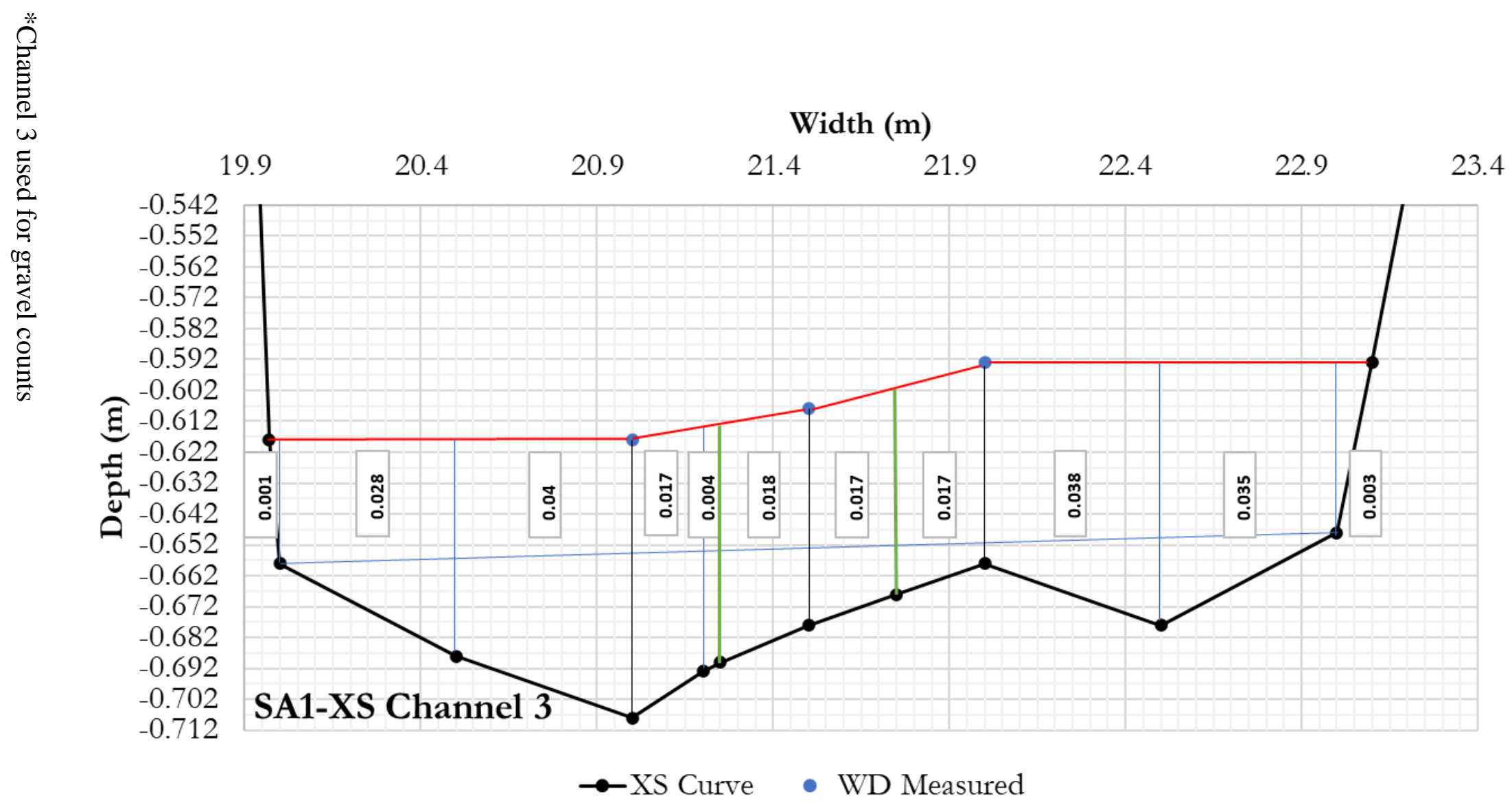

\& 


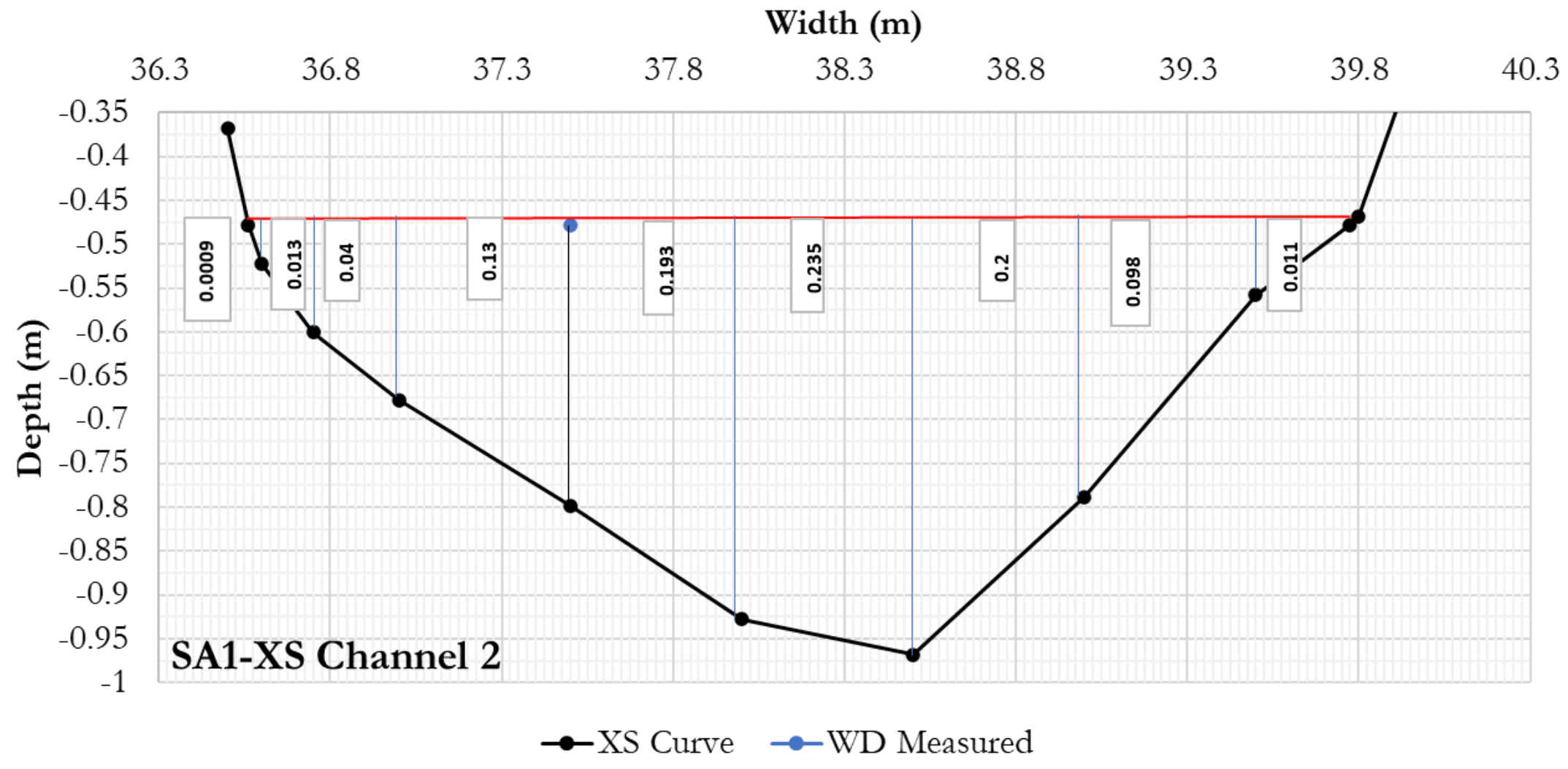

s 
SA1-XS Channel 1

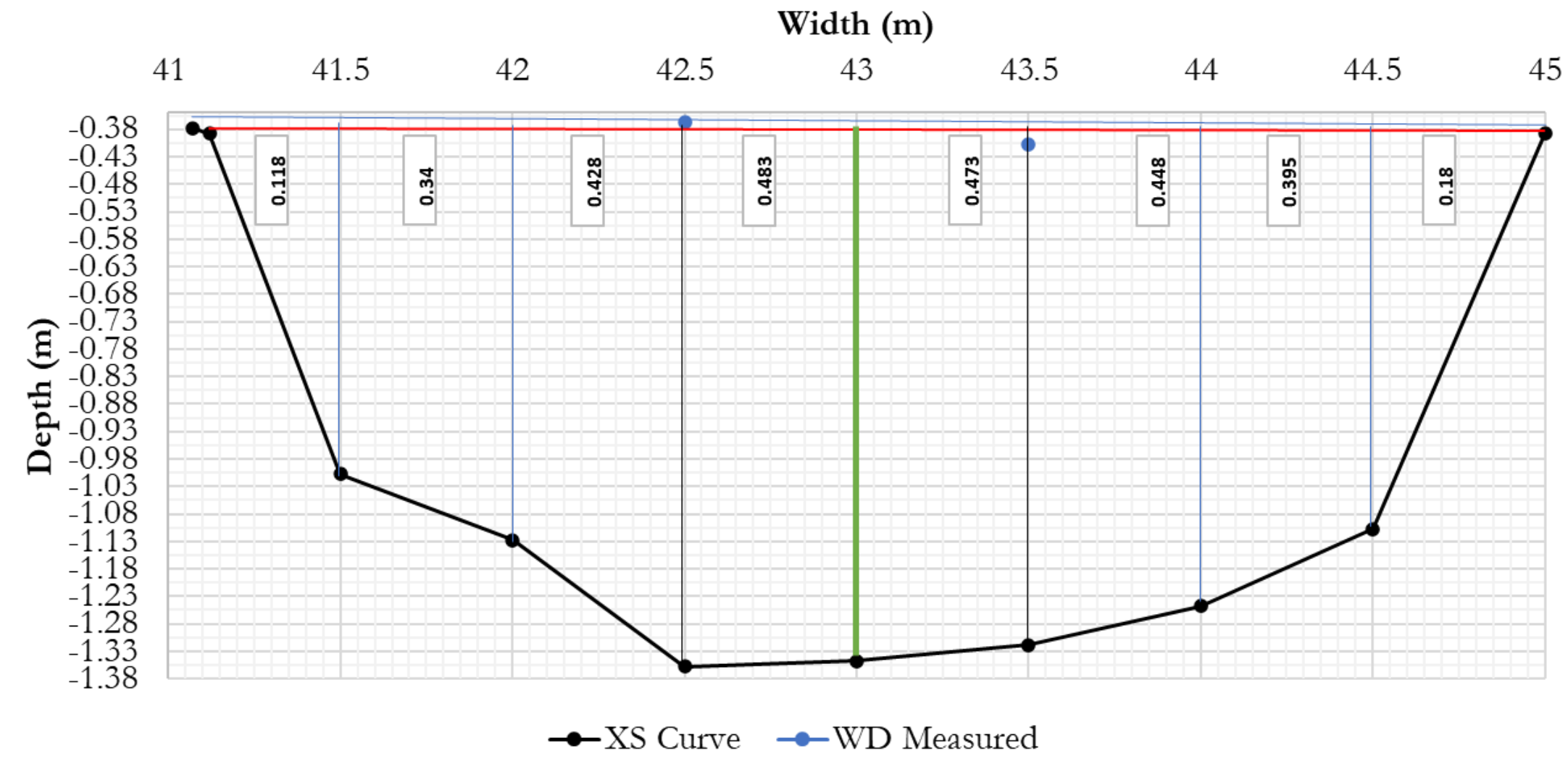




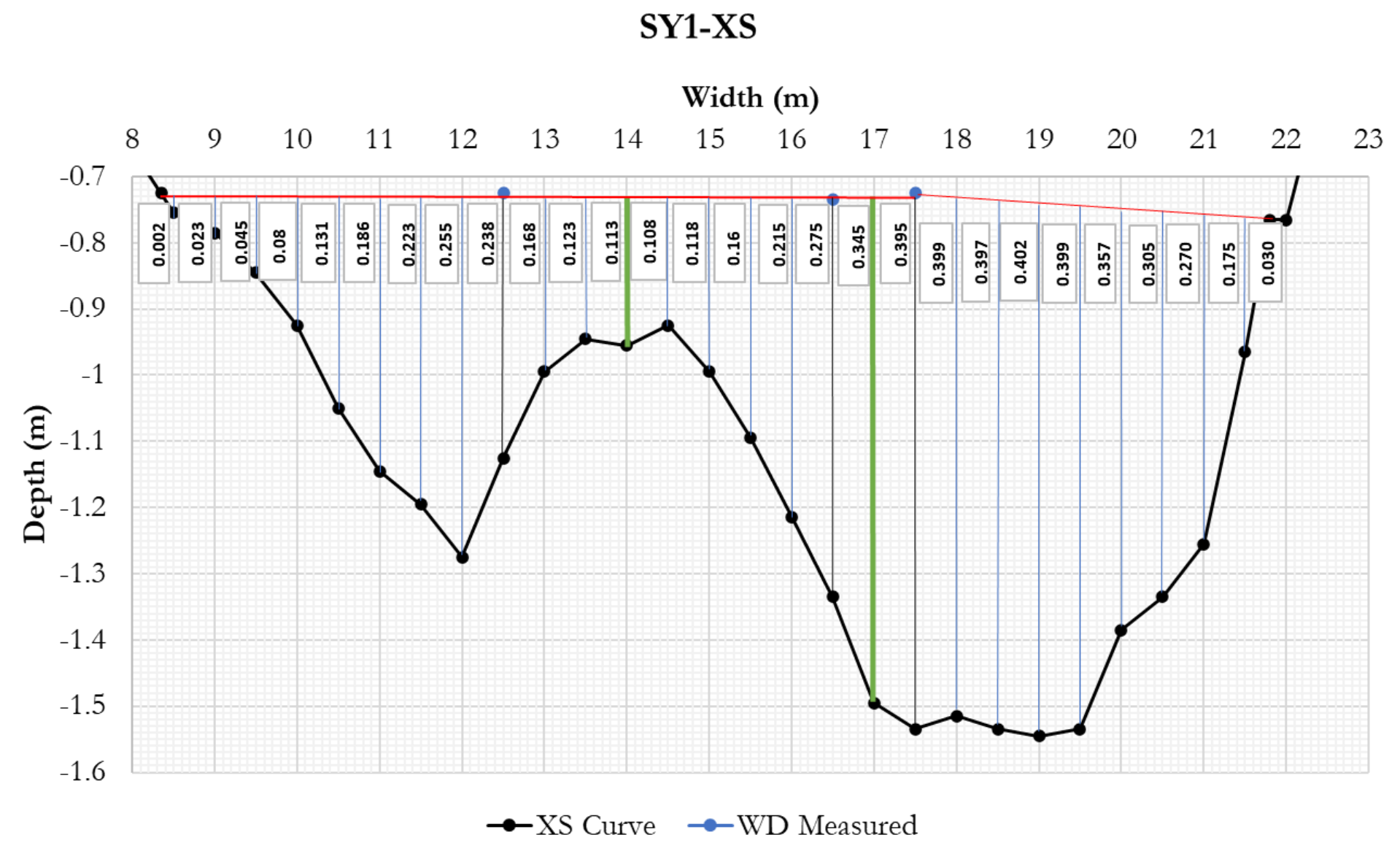

в 


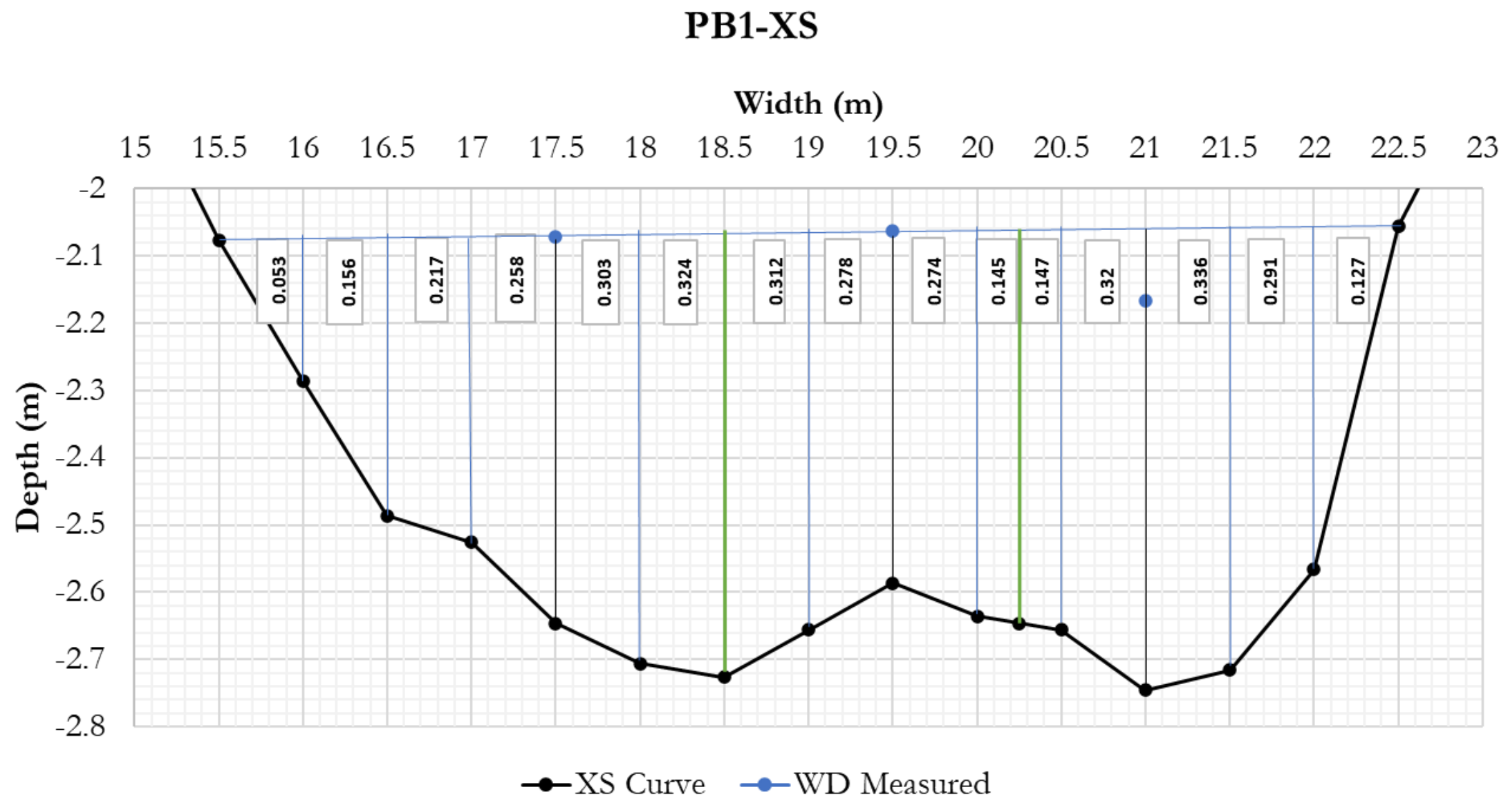

$\Xi$ 


\begin{tabular}{|c|c|c|c|c|c|c|c|c|c|c|c|c|c|c|c|c|}
\hline $\begin{array}{c}\text { Gravel } \\
\text { Grab }\end{array}$ & $\begin{array}{l}\text { Mass } \\
\text { Error }\end{array}$ & $\begin{array}{c}90 \\
\mathrm{~mm}\end{array}$ & $\begin{array}{c}64 \\
\mathrm{~mm}\end{array}$ & $\begin{array}{c}45 \\
\mathrm{~mm}\end{array}$ & $\begin{array}{c}32 \\
\mathbf{m m}\end{array}$ & $\begin{array}{c}22.6 \\
\mathrm{~m}\end{array}$ & $\begin{array}{c}16 \\
\mathrm{~mm}\end{array}$ & $\begin{array}{c}8 \\
\mathrm{~mm}\end{array}$ & $\begin{array}{c}4 \\
\mathrm{~mm}\end{array}$ & $\begin{array}{c}2 \\
\mathrm{~mm}\end{array}$ & $\begin{array}{c}1 \\
\mathbf{m m}\end{array}$ & $\begin{array}{l}0.5 \\
\mathrm{~mm}\end{array}$ & $\begin{array}{r}0.25 \\
\mathrm{~mm}\end{array}$ & $\begin{array}{c}0.125 \\
\mathrm{~mm}\end{array}$ & $\begin{array}{c}0.063 \\
\mathrm{~mm}\end{array}$ & $\begin{array}{c}<0.063 \\
\mathrm{~mm}\end{array}$ \\
\hline CH-L & 0 & 0 & 0 & 59.36 & 9.2 & 5.17 & 5.11 & 11.4 & 4.98 & 2.64 & 1.35 & 0.52 & 0.14 & 0.04 & 0.03 & 0.07 \\
\hline CH-M & 0.01 & 0 & 0 & 20.13 & 9.02 & 7.6 & 11.49 & 15 & 10.9 & 9.84 & 9.89 & 4.28 & 1.27 & 0.27 & 0.15 & 0.17 \\
\hline CH-R & 0 & 30.11 & 32.28 & 14.56 & 16.49 & 5.55 & 0 & 0.78 & 0.2 & 0.03 & 0 & 0 & 0 & 0 & 0 & 0 \\
\hline SB-L & 0 & 0 & 0 & 36.7 & 16.03 & 20.9 & 10.81 & 5.21 & 2.01 & 2.29 & 2.89 & 1.96 & 0.82 & 0.16 & 0.07 & 0.08 \\
\hline SB-R & 0 & 0 & 57.72 & 23.59 & 10.59 & 2.5 & 2.51 & 1.57 & 0.47 & 0.43 & 0.4 & 0.14 & 0.04 & 0.01 & 0.01 & 0 \\
\hline VC-L & 0 & 0 & 43.75 & 23.58 & 15.81 & 6.37 & 4.44 & 5.08 & 0.86 & 0.08 & 0.01 & 0 & 0 & 0 & 0 & 0 \\
\hline VC-R & 0.02 & 0 & 0 & 0 & 35.34 & 13.17 & 11.07 & 14.2 & 11.2 & 5.88 & 4.7 & 3.16 & 0.93 & 0.17 & 0.09 & 0.07 \\
\hline CA-R & 0.01 & 0 & 0 & 0 & 12.08 & 36.72 & 20.4 & 25.1 & 3.9 & 1.01 & 0.4 & 0.19 & 0.08 & 0.04 & 0.03 & 0.02 \\
\hline CA-L & 0.01 & 0 & 33.29 & 10.59 & 25.47 & 5.92 & 7.92 & 8.99 & 1.95 & 1.44 & 1.22 & 1.62 & 1.15 & 0.32 & 0.11 & 0.05 \\
\hline CA-M & 0 & 0 & 0 & 0 & 19.17 & 12.91 & 20.81 & 20.1 & 4.48 & 3.18 & 4.79 & 7.38 & 5.14 & 1.53 & 0.35 & 0.15 \\
\hline SA-M & 0.03 & 0 & 0 & 0 & 8.07 & 26.66 & 19.68 & 16.1 & 6.21 & 5.36 & 7.55 & 7.11 & 2.65 & 0.48 & 0.09 & 0.08 \\
\hline SA-M & 0.02 & 0 & 0 & 0 & 7.77 & 19.81 & 18.04 & 23.6 & 8.45 & 6.32 & 6.81 & 6.35 & 2.42 & 0.4 & 0.06 & 0.09 \\
\hline SA-R & 0.01 & 0 & 0 & 11.2 & 46.41 & 18.96 & 7.29 & 7.93 & 3.22 & 1.35 & 1.63 & 1.54 & 0.52 & 0.09 & 0.03 & 0.02 \\
\hline
\end{tabular}




\begin{tabular}{|c|c|c|c|c|c|c|c|c|}
\hline Sample ID & $\begin{array}{c}4 \\
\mathrm{~mm}\end{array}$ & $\begin{array}{c}2 \\
\mathbf{m m}\end{array}$ & $\begin{array}{c}\mathbf{1} \\
\mathbf{m m}\end{array}$ & $\begin{array}{c}0.5 \\
\mathrm{~mm}\end{array}$ & $\begin{array}{l}0.25 \\
\mathrm{~mm}\end{array}$ & $\begin{array}{c}0.125 \\
\mathrm{~mm}\end{array}$ & $\begin{array}{c}0.063 \\
\mathrm{~mm}\end{array}$ & $\begin{array}{c}<0.063 \\
\mathrm{~mm}\end{array}$ \\
\hline CH_1_11 & 20.37 & 21.24 & 33.96 & 16.91 & 4.75 & 1.24 & 0.69 & 0.78 \\
\hline CH_1_8 & 56.07 & 13.15 & 15.08 & 9.23 & 3.87 & 1.40 & 0.63 & 0.53 \\
\hline $\mathrm{CH} \_2 \_7 \_3.5 \mathrm{D}$ & 1.08 & 7.27 & 45.93 & 36.85 & 5.06 & 1.45 & 1.08 & 1.24 \\
\hline SB_0_13_3.5U & 54.20 & 17.02 & 12.53 & 9.16 & 4.87 & 1.46 & 0.45 & 0.29 \\
\hline SB_1_15 & 2.38 & 3.69 & 9.43 & 29.62 & 41.72 & 11.99 & 0.93 & 0.03 \\
\hline SB_1_14 & 36.15 & 17.74 & 19.97 & 15.73 & 8.00 & 1.70 & 0.40 & 0.31 \\
\hline SB_1_13 & 25.80 & 13.81 & 28.73 & 24.10 & 6.24 & 1.07 & 0.17 & 0.17 \\
\hline SB_2_13_4D & 63.11 & 14.73 & 11.10 & 7.17 & 2.99 & 0.56 & 0.17 & 0.17 \\
\hline VC_1_18 & 31.16 & 7.76 & 12.11 & 15.10 & 14.56 & 9.25 & 5.99 & 3.81 \\
\hline VC_1_13.7 & 61.81 & 14.02 & 10.29 & 8.45 & 3.88 & 0.80 & 0.35 & 0.35 \\
\hline VC_1.5_18 & 66.84 & 12.90 & 10.37 & 6.54 & 2.66 & 0.52 & 0.13 & 0.09 \\
\hline VC_1.5_15 & 68.56 & 11.26 & 9.31 & 6.19 & 3.33 & 0.91 & 0.29 & 0.22 \\
\hline VC_2_26 & 45.19 & 19.96 & 13.13 & 8.48 & 5.27 & 2.90 & 2.07 & 2.90 \\
\hline CA_1_25.5 & 65.38 & 5.24 & 7.60 & 10.38 & 7.69 & 2.13 & 0.83 & 0.65 \\
\hline CA_1_22 & 71.71 & 7.42 & 7.80 & 6.96 & 4.01 & 1.20 & 0.46 & 0.35 \\
\hline CA_2_5 & 60.85 & 6.50 & 9.80 & 13.17 & 8.52 & 1.04 & 0.12 & 0.06 \\
\hline CA_2_2 & 0.68 & 4.27 & 32.04 & 47.92 & 11.67 & 1.94 & 0.82 & 0.67 \\
\hline SA_0_43U & 56.24 & 5.44 & 6.93 & 12.15 & 13.64 & 3.72 & 1.05 & 0.78 \\
\hline SA_0_38U & 4.49 & 4.82 & 7.80 & 12.95 & 34.38 & 20.24 & 7.59 & 7.67 \\
\hline SA_0_11U & 16.24 & 10.55 & 13.43 & 16.74 & 20.66 & 11.16 & 6.08 & 5.08 \\
\hline SA_1_43 & 48.14 & 3.01 & 9.65 & 21.68 & 14.25 & 2.48 & 0.53 & 0.27 \\
\hline SA_1_36.6 & 6.06 & 4.85 & 8.39 & 19.57 & 36.35 & 16.96 & 4.94 & 2.94 \\
\hline SA_1_23 & 29.20 & 5.63 & 9.15 & 26.11 & 23.62 & 4.93 & 0.76 & 0.54 \\
\hline SA_1_21.2 & 49.21 & 7.28 & 9.35 & 12.51 & 15.64 & 5.21 & 0.63 & 0.17 \\
\hline SA_1_15.7 & 8.65 & 15.41 & 18.55 & 17.17 & 15.04 & 8.90 & 6.14 & 10.03 \\
\hline SA_1_15 & 16.53 & 5.23 & 11.67 & 10.36 & 10.55 & 17.09 & 15.97 & 12.61 \\
\hline SA_2_41.3D & 1.07 & 1.99 & 14.67 & 42.99 & 27.28 & 6.34 & 2.48 & 3.06 \\
\hline SA_2_38D & 3.59 & 3.74 & 5.30 & 24.65 & 41.81 & 12.48 & 4.06 & 4.21 \\
\hline SA_2_11D & 18.79 & 17.47 & 13.86 & 11.57 & 11.32 & 9.27 & 7.96 & 9.60 \\
\hline SY_1_17 & 0.00 & 0.24 & 10.32 & 60.08 & 26.40 & 2.34 & 0.44 & 0.21 \\
\hline SY_1_16 & 43.65 & 13.13 & 15.61 & 13.50 & 8.08 & 4.21 & 1.40 & 0.40 \\
\hline SY_1_11 & 2.30 & 5.19 & 10.77 & 13.81 & 23.99 & 27.27 & 11.17 & 5.40 \\
\hline SY_1_32.5_7D & 0.00 & 2.12 & 18.38 & 39.44 & 37.21 & 2.44 & 0.15 & 0.09 \\
\hline
\end{tabular}




\begin{tabular}{|c|c|c|c|c|c|c|c|c|}
\hline PB_1_21 & 34.34 & 13.50 & 10.01 & 7.68 & 6.29 & 6.05 & 7.80 & 14.09 \\
\hline PB_1_19.5 & 34.71 & 3.26 & 4.05 & 12.21 & 22.64 & 10.72 & 6.53 & 5.82 \\
\hline PB_1_17.5 & 30.35 & 4.36 & 12.22 & 23.49 & 17.78 & 5.51 & 3.51 & 2.70 \\
\hline PB_2_22 & 3.55 & 7.09 & 13.51 & 24.16 & 23.48 & 11.32 & 8.95 & 7.43 \\
\hline PB_2_21 & 1.18 & 15.34 & 25.07 & 16.22 & 10.62 & 7.96 & 7.96 & 15.63 \\
\hline PB_2_19 & 38.87 & 2.80 & 3.43 & 12.23 & 26.28 & 9.59 & 3.87 & 2.92 \\
\hline PB_2_15 & 0.07 & 1.60 & 5.94 & 35.26 & 46.21 & 8.24 & 1.67 & 1.00 \\
\hline PB_3_22 & 28.07 & 5.38 & 9.99 & 23.11 & 22.09 & 7.22 & 2.59 & 1.44 \\
\hline PB_3_21 & 5.28 & 12.93 & 14.48 & 11.78 & 9.78 & 9.27 & 16.34 & 19.69 \\
\hline PB_3_19 & 3.48 & 10.57 & 14.88 & 11.54 & 8.21 & 7.65 & 14.74 & 28.79 \\
\hline CH_0_6_1U & 14.63 & 16.38 & 19.10 & 17.58 & 15.28 & 8.84 & 4.80 & 3.28 \\
\hline CH_1_13.1 & 33.37 & 11.18 & 18.74 & 14.93 & 11.66 & 5.29 & 2.50 & 2.20 \\
\hline CH_1_9.8 & 78.56 & 8.03 & 6.99 & 3.71 & 1.74 & 0.48 & 0.24 & 0.25 \\
\hline CH_1_6.5 & 35.85 & 16.17 & 12.35 & 9.79 & 9.93 & 7.20 & 4.54 & 4.11 \\
\hline CH_1_5 & 35.37 & 14.51 & 11.06 & 11.12 & 12.94 & 7.92 & 4.11 & 2.96 \\
\hline SB_1_19 & 1.79 & 4.14 & 8.77 & 25.67 & 41.60 & 13.88 & 3.02 & 1.15 \\
\hline SB_1_10 & 2.62 & 6.53 & 11.82 & 23.85 & 32.83 & 15.30 & 4.81 & 2.23 \\
\hline SB_1_3.4 & 8.49 & 4.94 & 8.59 & 9.94 & 30.60 & 22.81 & 10.07 & 4.53 \\
\hline VC_1_28 & 22.50 & 11.55 & 13.69 & 18.28 & 21.47 & 8.36 & 2.52 & 1.48 \\
\hline VC_1_5 & 44.78 & 6.99 & 8.46 & 13.67 & 14.30 & 6.37 & 2.92 & 2.40 \\
\hline VC_2_9 & 1.71 & 1.62 & 9.70 & 41.38 & 37.27 & 6.45 & 1.17 & 0.72 \\
\hline CA_1_35.5 & 23.32 & 22.16 & 16.62 & 10.50 & 5.54 & 6.12 & 6.71 & 8.16 \\
\hline CA_1_28 & 0.44 & 5.69 & 14.29 & 21.72 & 28.28 & 15.01 & 8.02 & 6.56 \\
\hline CA_1_18.5 & 0.12 & 3.72 & 11.28 & 12.97 & 24.85 & 20.41 & 15.01 & 11.76 \\
\hline CA_1_11 & 3.36 & 21.07 & 21.56 & 13.45 & 10.68 & 9.69 & 9.30 & 10.78 \\
\hline CA_2_10 & 0.55 & 7.29 & 15.68 & 19.67 & 26.00 & 15.27 & 8.12 & 7.43 \\
\hline CA_2_.5 & 0.00 & 3.21 & 16.36 & 20.11 & 25.84 & 18.50 & 9.48 & 6.50 \\
\hline SA_1_46.2 & 29.40 & 26.13 & 22.14 & 10.89 & 4.54 & 2.54 & 1.63 & 2.72 \\
\hline SA_1_30 & 1.10 & 4.08 & 10.05 & 33.12 & 41.44 & 8.32 & 1.26 & 0.63 \\
\hline SA_1_16.7 & 0.76 & 6.85 & 13.52 & 20.42 & 31.07 & 16.44 & 5.79 & 5.15 \\
\hline SA_1_13.5 & 15.53 & 19.47 & 17.74 & 18.67 & 16.27 & 6.28 & 2.90 & 3.20 \\
\hline SY_1_53 & 20.56 & 11.63 & 13.50 & 18.69 & 23.26 & 9.24 & 2.18 & 1.04 \\
\hline SY_1_39 & 2.30 & 4.10 & 4.92 & 18.45 & 48.53 & 19.22 & 1.53 & 0.86 \\
\hline SY_1_26 & 34.93 & 9.59 & 17.99 & 19.15 & 13.66 & 3.39 & 0.76 & 0.45 \\
\hline SY_1_24 & 0.00 & 0.71 & 2.73 & 14.70 & 52.95 & 21.62 & 4.56 & 2.73 \\
\hline PB_1_27.5 & 17.71 & 6.46 & 16.42 & 27.31 & 16.79 & 5.54 & 4.06 & 5.17 \\
\hline PB_3_27 & 14.54 & 8.77 & 12.51 & 20.80 & 20.06 & 9.99 & 7.55 & 5.85 \\
\hline PB_3_16 & 9.79 & 5.79 & 10.02 & 25.84 & 30.46 & 10.73 & 3.92 & 3.37 \\
\hline
\end{tabular}


APPENDIX D: Bulk metals data

\begin{tabular}{|c|c|c|c|c|c|c|c|c|}
\hline $\mathbf{X S}$ & Rep & $\mathrm{Cr}$ & $\mathbf{C u}$ & $\mathbf{Z n}$ & As & Cd & $\mathrm{Hg}$ & $\mathbf{P b}$ \\
\hline PB_3_16 & $\mathrm{R} 1$ & 32 & 62 & 83 & 9 & $<\mathrm{LOD}$ & $<\mathrm{LOD}$ & 13.8 \\
\hline PB_3_16 & $\mathrm{R} 2$ & 29 & 72 & 85.4 & 8.9 & $<\mathrm{LOD}$ & 3.4 & 14.3 \\
\hline PB_3_16 & $\mathrm{R} 3$ & 26 & 46.1 & 67.9 & 5.8 & $<\mathrm{LOD}$ & $<\mathrm{LOD}$ & 17.1 \\
\hline PB_3_16 & $\mathrm{R} 4$ & 22 & 35.2 & 56.9 & 3.9 & $<\mathrm{LOD}$ & 3.4 & 14.8 \\
\hline PB_3_16 & $\mathrm{R} 5$ & 28 & 48 & 76.1 & 6.5 & $<\mathrm{LOD}$ & $<\mathrm{LOD}$ & 15.8 \\
\hline PB_3_16 & R6 & 28 & 38.9 & 82.8 & 7.5 & $<\mathrm{LOD}$ & 4.7 & 19.4 \\
\hline PB_3_16 & R7 & 28 & 41.3 & 70.8 & 7.5 & $<\mathrm{LOD}$ & 3.3 & 14.9 \\
\hline PB_3_19 & $\mathrm{R} 1$ & 28 & 63 & 89.4 & 20.8 & $<\mathrm{LOD}$ & 5.1 & 23.5 \\
\hline PB_3_19 & $\mathrm{R} 2$ & 29 & 67 & 80.7 & 19.7 & $<\mathrm{LOD}$ & 4 & 22.7 \\
\hline PB_3_19 & R3 & 47 & 96 & 113 & 29.8 & $<\mathrm{LOD}$ & 5.5 & 26.9 \\
\hline PB_3_19 & $\mathrm{R} 4$ & 29 & 61 & 87.9 & 20.7 & $<\mathrm{LOD}$ & 5.1 & 23.3 \\
\hline PB_3_19 & $\mathrm{R} 5$ & 29 & 65 & 89.5 & 19.9 & $<\mathrm{LOD}$ & 4.4 & 25.7 \\
\hline PB_3_19 & R6 & 38 & 60 & 87 & 20 & $<\mathrm{LOD}$ & 5.8 & 26.4 \\
\hline PB_3_21 & $\mathrm{R} 1$ & 26 & 92 & 85.5 & 14.4 & $<\mathrm{LOD}$ & 3.8 & 25.2 \\
\hline PB_3_21 & $\mathrm{R} 2$ & 29 & 90 & 79.8 & 14.8 & $<\mathrm{LOD}$ & 3.9 & 21.9 \\
\hline PB_3_21 & $\mathrm{R} 3$ & 31 & 93 & 83.6 & 15.9 & $<\mathrm{LOD}$ & 7.9 & 22.1 \\
\hline PB_3_21 & $\mathrm{R} 4$ & 29 & 74 & 78.1 & 13.3 & $<\mathrm{LOD}$ & 4.6 & 24.3 \\
\hline PB_3_21 & $\mathrm{R} 5$ & 31 & 80 & 83.4 & 15.1 & $<\mathrm{LOD}$ & $<\mathrm{LOD}$ & 26.2 \\
\hline PB_3_21 & R6 & 28 & 83 & 84.7 & 12 & $<\mathrm{LOD}$ & 3.7 & 26 \\
\hline PB_3_22 & $\mathrm{R} 1$ & 18.2 & 74 & 55.4 & 4.2 & $<\mathrm{LOD}$ & $<\mathrm{LOD}$ & 12.1 \\
\hline PB_3_22 & $\mathrm{R} 2$ & 22 & 87 & 80.5 & 8.1 & $<\mathrm{LOD}$ & $<\mathrm{LOD}$ & 10.4 \\
\hline PB_3_22 & $\mathrm{R} 3$ & 13.5 & 59 & 50.8 & 4.6 & $<\mathrm{LOD}$ & $<\mathrm{LOD}$ & 9.8 \\
\hline PB_3_22 & $\mathrm{R} 4$ & 17.7 & 76 & 62.7 & 7 & $<\mathrm{LOD}$ & 2.9 & 8 \\
\hline PB_3_22 & $\mathrm{R} 5$ & 14.8 & 51.6 & 49.3 & 4.1 & $<\mathrm{LOD}$ & $<\mathrm{LOD}$ & 8.7 \\
\hline PB_3_22 & R6 & 14.9 & 62 & 53.9 & 4.7 & $<\mathrm{LOD}$ & $<\mathrm{LOD}$ & 11.3 \\
\hline PB_3_27 & $\mathrm{R} 1$ & 23 & 86 & 87.7 & 8.9 & $<\mathrm{LOD}$ & 4 & 16.1 \\
\hline PB_3_27 & $\mathrm{R} 2$ & 24 & 87 & 96.8 & 9.7 & $<\mathrm{LOD}$ & 4.3 & 16.5 \\
\hline PB_3_27 & R3 & 25 & 69 & 85 & 11.5 & 2.8 & 3 & 15.5 \\
\hline PB_3_27 & $\mathrm{R} 4$ & 27 & 80 & 88.4 & 8.3 & $<\mathrm{LOD}$ & 3.9 & 15.8 \\
\hline PB_3_27 & $\mathrm{R} 5$ & 22 & 69 & 88.4 & 9.5 & $<\mathrm{LOD}$ & $<\mathrm{LOD}$ & 15.7 \\
\hline PB_3_27 & R6 & 21 & 59 & 85.9 & 9.9 & $<\mathrm{LOD}$ & $<\mathrm{LOD}$ & 15.3 \\
\hline PB_2_15 & $\mathrm{R} 1$ & 19.4 & 32.8 & 36 & 2.5 & $<\mathrm{LOD}$ & 3.3 & 14.1 \\
\hline PB_2_15 & $\mathrm{R} 2$ & 19 & 25.9 & 38.7 & 2.8 & $<\mathrm{LOD}$ & $<\mathrm{LOD}$ & 14.8 \\
\hline PB_2_15 & $\mathrm{R} 3$ & 18.8 & 31.6 & 36.6 & $<\mathrm{LOD}$ & $<\mathrm{LOD}$ & 3.2 & 14.3 \\
\hline PB_2_15 & $\mathrm{R} 4$ & 18.5 & 30.3 & 37.2 & 6.5 & $<\mathrm{LOD}$ & $<\mathrm{LOD}$ & 13.8 \\
\hline PB_2_15 & $\mathrm{R} 5$ & 17.1 & 30.9 & 39.2 & 5.1 & $<\mathrm{LOD}$ & $<\mathrm{LOD}$ & 13.1 \\
\hline PB_2_15 & R6 & 14.6 & 26.7 & 37.3 & 4.7 & $<\mathrm{LOD}$ & $<\mathrm{LOD}$ & 12.2 \\
\hline PB_2_15 & R7 & 17.7 & 31.9 & 39.6 & 3.9 & $<\mathrm{LOD}$ & $<\mathrm{LOD}$ & 12.9 \\
\hline
\end{tabular}




\begin{tabular}{|c|c|c|c|c|c|c|c|c|}
\hline PB_2_19 & $\mathrm{R} 1$ & 22 & 136 & 129 & 92 & $<\mathrm{LOD}$ & 6.3 & 32.3 \\
\hline PB_2_19 & $\mathrm{R} 2$ & 19 & 110 & 118 & 86.8 & $<\mathrm{LOD}$ & 4.5 & 33.3 \\
\hline PB_2_19 & R3 & 18 & 108 & 121 & 91.4 & $<\mathrm{LOD}$ & 6.2 & 33.6 \\
\hline PB_2_19 & $\mathrm{R} 4$ & 23 & 101 & 123 & 87.1 & $<\mathrm{LOD}$ & 5.3 & 34.3 \\
\hline PB_2_19 & R5 & 19 & 104 & 123 & 90.3 & $<\mathrm{LOD}$ & 7.2 & 32.6 \\
\hline PB_2_19 & R6 & 26 & 93 & 129 & 91.1 & $<\mathrm{LOD}$ & 5 & 35.5 \\
\hline PB_2_21 & $\mathrm{R} 1$ & 35 & 66 & 98.7 & 17.9 & $<\mathrm{LOD}$ & 6 & 34.3 \\
\hline PB_2_21 & $\mathrm{R} 2$ & 29 & 67 & 98 & 16.8 & $<\mathrm{LOD}$ & 5 & 32.5 \\
\hline PB_2_21 & R3 & 28 & 71 & 104 & 16.7 & $<\mathrm{LOD}$ & 6.9 & 35.7 \\
\hline PB_2_21 & $\mathrm{R} 4$ & 31 & 60 & 97 & 17.8 & $<\mathrm{LOD}$ & 3.6 & 33.7 \\
\hline PB_2_21 & R5 & 29 & 60 & 98.2 & 18.5 & $<\mathrm{LOD}$ & 6.5 & 34.9 \\
\hline PB_2_21 & R6 & 31 & 61 & 101 & 14.6 & $<\mathrm{LOD}$ & 4.5 & 36.9 \\
\hline PB_2_22 & $\mathrm{R} 1$ & 24 & 81 & 112 & 13.3 & $<\mathrm{LOD}$ & 3.8 & 15.8 \\
\hline PB_2_22 & $\mathrm{R} 2$ & 23 & 61 & 114 & 11.8 & $<\mathrm{LOD}$ & $<\mathrm{LOD}$ & 15.3 \\
\hline PB_2_22 & $\mathrm{R} 3$ & 27 & 73 & 125 & 15.8 & $<\mathrm{LOD}$ & $<\mathrm{LOD}$ & 15 \\
\hline PB_2_22 & $\mathrm{R} 4$ & 28 & 77 & 114 & 13.2 & $<\mathrm{LOD}$ & 3.1 & 18.3 \\
\hline PB_2_22 & R5 & 22 & 81 & 120 & 14.6 & $<\mathrm{LOD}$ & 4.6 & 14.6 \\
\hline PB_2_22 & R6 & 23 & 73 & 132 & 16.1 & $<\mathrm{LOD}$ & 4.1 & 16.4 \\
\hline PB_1_17.5 & $\mathrm{R} 1$ & 19 & 43.2 & 55.1 & 9.1 & $<\mathrm{LOD}$ & $<\mathrm{LOD}$ & 16.5 \\
\hline PB_1_17.5 & $\mathrm{R} 2$ & 22 & 46 & 60.8 & 9.9 & $<\mathrm{LOD}$ & $<$ LOD & 13.5 \\
\hline PB_1_17.5 & R3 & 18 & 64 & 76.6 & 12.3 & $<\mathrm{LOD}$ & 4 & 16.4 \\
\hline PB_1_17.5 & $\mathrm{R} 4$ & 18.7 & 32 & 43.2 & 6.8 & $<\mathrm{LOD}$ & $<\mathrm{LOD}$ & 12 \\
\hline PB_1_17.5 & $\mathrm{R} 5$ & 24 & 57 & 74.5 & 12.7 & $<\mathrm{LOD}$ & 4.8 & 18.4 \\
\hline PB_1_17.5 & R6 & 23 & 48 & 66.9 & 11.3 & $<\mathrm{LOD}$ & $<\mathrm{LOD}$ & 14.5 \\
\hline PB_1_19.5 & $\mathrm{R} 1$ & 25 & 76 & 149 & 19.4 & $<\mathrm{LOD}$ & $<\mathrm{LOD}$ & 18.9 \\
\hline PB_1_19.5 & $\mathrm{R} 2$ & 27 & 99 & 254 & 36.6 & $<\mathrm{LOD}$ & 6.2 & 23.5 \\
\hline PB_1_19.5 & $\mathrm{R} 3$ & 24 & 72 & 168 & 21.3 & $<\mathrm{LOD}$ & 5.4 & 21.6 \\
\hline PB_1_19.5 & $\mathrm{R} 4$ & 24 & 63 & 150 & 20.1 & $<\mathrm{LOD}$ & $<\mathrm{LOD}$ & 18.3 \\
\hline PB_1_19.5 & R5 & 31 & 76 & 166 & 19.6 & $<\mathrm{LOD}$ & 3.3 & 20.9 \\
\hline PB_1_19.5 & R6 & 21 & 69 & 190 & 22.2 & $<\mathrm{LOD}$ & $<\mathrm{LOD}$ & 18.2 \\
\hline PB_1_21 & $\mathrm{R} 1$ & 23 & 73 & 58 & 9.3 & $<\mathrm{LOD}$ & $<\mathrm{LOD}$ & 14.8 \\
\hline PB_1_21 & $\mathrm{R} 2$ & 12.2 & 42.8 & 44.9 & 7.7 & $<\mathrm{LOD}$ & $<\mathrm{LOD}$ & 8.6 \\
\hline PB_1_21 & $\mathrm{R} 3$ & 14.3 & 42.8 & 39 & 5.5 & $<\mathrm{LOD}$ & $<\mathrm{LOD}$ & 11 \\
\hline PB_1_21 & $\mathrm{R} 4$ & 23 & 77 & 55.8 & 9.4 & $<\mathrm{LOD}$ & $<\mathrm{LOD}$ & 14.5 \\
\hline PB_1_21 & $\mathrm{R} 5$ & 24 & 61 & 50.5 & 7.8 & $<\mathrm{LOD}$ & 4.4 & 12.8 \\
\hline PB_1_21 & R6 & 24 & 79 & 63.2 & 11.8 & $<\mathrm{LOD}$ & $<\mathrm{LOD}$ & 13.5 \\
\hline PB_1_27.5 & $\mathrm{R} 1$ & 28 & 67 & 126 & 14.8 & $<\mathrm{LOD}$ & $<$ LOD & 17.6 \\
\hline PB_1_27.5 & $\mathrm{R} 2$ & 32 & 79 & 126 & 13.4 & $<\mathrm{LOD}$ & 3.2 & 19.3 \\
\hline PB_1_27.5 & $\mathrm{R} 3$ & 28 & 66 & 134 & 15.5 & $<\mathrm{LOD}$ & 5 & 21.7 \\
\hline PB_1_27.5 & $\mathrm{R} 4$ & 27 & 57 & 108 & 12.1 & $<\mathrm{LOD}$ & $<\mathrm{LOD}$ & 16.7 \\
\hline PB_1_27.5 & R5 & 31 & 79 & 133 & 14.5 & $<\mathrm{LOD}$ & 4.5 & 20.6 \\
\hline PB_1_27.5 & R6 & 25 & 58 & 114 & 14.9 & $<\mathrm{LOD}$ & 3 & 17 \\
\hline
\end{tabular}




\begin{tabular}{|c|c|c|c|c|c|c|c|c|}
\hline SY_1_11 & $\mathrm{R} 1$ & 25 & 54 & 71.2 & 9.1 & $<\mathrm{LOD}$ & 4.3 & 14.3 \\
\hline SY_1_11 & $\mathrm{R} 2$ & 30 & 41 & 69.1 & 9.7 & $<\mathrm{LOD}$ & $<\mathrm{LOD}$ & 16.8 \\
\hline SY_1_11 & $\mathrm{R} 3$ & 18 & 71 & 79.5 & 7.7 & $<\mathrm{LOD}$ & 4.5 & 15.7 \\
\hline SY_1_11 & $\mathrm{R} 4$ & 23 & 41.6 & 68.8 & 7.7 & $<\mathrm{LOD}$ & 3.4 & 15.6 \\
\hline SY_1_11 & $\mathrm{R} 5$ & 20 & 50 & 73 & 7.6 & $<\mathrm{LOD}$ & 3.2 & 17.4 \\
\hline SY_1_11 & R6 & 27 & 62 & 81.9 & 7.8 & $<\mathrm{LOD}$ & 5.1 & 18.9 \\
\hline SY_1_16 & $\mathrm{R} 1$ & 16.3 & 52 & 35.7 & 4.3 & $<\mathrm{LOD}$ & 3.5 & 9.7 \\
\hline SY_1_16 & $\mathrm{R} 2$ & 14 & 59 & 38.5 & 5.2 & $<\mathrm{LOD}$ & $<\mathrm{LOD}$ & 10.5 \\
\hline SY_1_16 & $\mathrm{R} 3$ & 23 & 82 & 48.4 & 3.9 & $<\mathrm{LOD}$ & $<\mathrm{LOD}$ & 11.3 \\
\hline SY_1_16 & $\mathrm{R} 4$ & 23.9 & 77 & 45.6 & 3.7 & $<\mathrm{LOD}$ & $<\mathrm{LOD}$ & 9.4 \\
\hline SY_1_16 & $\mathrm{R} 5$ & 27 & 99 & 56.2 & 3.2 & $<\mathrm{LOD}$ & 3.7 & 15.1 \\
\hline SY_1_16 & R6 & 21.2 & 60 & 36.3 & 3 & $<\mathrm{LOD}$ & $<\mathrm{LOD}$ & 8.4 \\
\hline SY_1_16 & R7 & 21.2 & 75 & 42.5 & 4 & $<\mathrm{LOD}$ & 3.1 & 12.4 \\
\hline SY_1_17 & $\mathrm{R} 1$ & 16.9 & 41.1 & 31.3 & 5.5 & $<\mathrm{LOD}$ & $<\mathrm{LOD}$ & 8.2 \\
\hline SY_1_17 & $\mathrm{R} 2$ & 10.4 & 49 & 26.8 & $<\mathrm{LOD}$ & $<\mathrm{LOD}$ & $<\mathrm{LOD}$ & 8.9 \\
\hline SY_1_17 & $\mathrm{R} 3$ & 11.7 & 40.5 & 26.3 & 2.5 & $<\mathrm{LOD}$ & 3.7 & 7.1 \\
\hline SY_1_17 & $\mathrm{R} 4$ & 13.6 & 51.9 & 32.1 & $<\mathrm{LOD}$ & $<\mathrm{LOD}$ & $<\mathrm{LOD}$ & 7.1 \\
\hline SY_1_17 & $\mathrm{R} 5$ & 9.6 & 34.1 & 28.7 & $<\mathrm{LOD}$ & $<\mathrm{LOD}$ & $<\mathrm{LOD}$ & 9 \\
\hline SY_1_17 & R6 & 12.6 & 61 & 36.3 & $<\mathrm{LOD}$ & $<\mathrm{LOD}$ & $<\mathrm{LOD}$ & 12.9 \\
\hline SY_1_24 & $\mathrm{R} 1$ & 20 & 31.2 & 70.4 & 3.3 & $<\mathrm{LOD}$ & 3.9 & 15.1 \\
\hline SY_1_24 & $\mathrm{R} 2$ & 25 & 27.7 & 61.9 & 5.5 & $<\mathrm{LOD}$ & $<\mathrm{LOD}$ & 12.1 \\
\hline SY_1_24 & $\mathrm{R} 3$ & 13.3 & 23.4 & 52.6 & 3.5 & $<\mathrm{LOD}$ & $<\mathrm{LOD}$ & 12.2 \\
\hline SY_1_24 & $\mathrm{R} 4$ & 16 & 28 & 66.1 & 6.7 & $<\mathrm{LOD}$ & $<\mathrm{LOD}$ & 12.4 \\
\hline SY_1_24 & $\mathrm{R} 5$ & 18 & 30 & 53.6 & 3.8 & $<\mathrm{LOD}$ & 2.9 & 11.6 \\
\hline SY_1_24 & R6 & 19 & 28.1 & 62.8 & 5.9 & $<\mathrm{LOD}$ & $<\mathrm{LOD}$ & 12.2 \\
\hline SY_1_26 & $\mathrm{R} 1$ & 14.6 & 34.4 & 31.5 & 2.9 & $<\mathrm{LOD}$ & 3.2 & 8.4 \\
\hline SY_1_26 & $\mathrm{R} 2$ & 12.5 & 36.9 & 27.9 & 2.9 & $<\mathrm{LOD}$ & 3.3 & 9.4 \\
\hline SY_1_26 & $\mathrm{R} 3$ & 13 & 38.4 & 32.9 & 2.9 & $<\mathrm{LOD}$ & 4.1 & 9.6 \\
\hline SY_1_26 & $\mathrm{R} 4$ & 10.3 & 25.6 & 24.3 & 2.1 & $<\mathrm{LOD}$ & $<\mathrm{LOD}$ & 9.5 \\
\hline SY_1_26 & $\mathrm{R} 5$ & 13.1 & 29.1 & 25.6 & 2.4 & $<\mathrm{LOD}$ & $<\mathrm{LOD}$ & 6.8 \\
\hline SY_1_26 & R6 & 35 & 67 & 44.7 & 5.6 & $<\mathrm{LOD}$ & $<\mathrm{LOD}$ & 10.1 \\
\hline SY_1_32.5 & $\mathrm{R} 1$ & 13.7 & 57 & 33.3 & $<\mathrm{LOD}$ & $<\mathrm{LOD}$ & 3.2 & 11.7 \\
\hline SY_1_32.5 & $\mathrm{R} 2$ & 21 & 99 & 48.8 & 3.8 & $<\mathrm{LOD}$ & $<\mathrm{LOD}$ & 9.3 \\
\hline SY_1_32.5 & $\mathrm{R} 3$ & 13.3 & 44.4 & 26.6 & $<\mathrm{LOD}$ & $<\mathrm{LOD}$ & $<\mathrm{LOD}$ & 9.3 \\
\hline SY_1_32.5 & $\mathrm{R} 4$ & 13.1 & 39.7 & 27.9 & $<\mathrm{LOD}$ & $<\mathrm{LOD}$ & $<\mathrm{LOD}$ & 7.5 \\
\hline SY_1_32.5 & $\mathrm{R} 5$ & 12.8 & 43.6 & 29.3 & 2.6 & $<\mathrm{LOD}$ & 3.1 & 7.2 \\
\hline SY_1_32.5 & R6 & 13.8 & 34 & 27.9 & 3.4 & $<\mathrm{LOD}$ & 2.8 & 8.7 \\
\hline
\end{tabular}




\begin{tabular}{|c|c|c|c|c|c|c|c|c|}
\hline SY_1_39 & $\mathrm{R} 1$ & 17.8 & 49.6 & 42.7 & 3.8 & $<\mathrm{LOD}$ & $<$ LOD & 9.5 \\
\hline SY_1_39 & $\mathrm{R} 2$ & 14.6 & 36.9 & 35.7 & 3.9 & $<\mathrm{LOD}$ & 3.1 & 8.9 \\
\hline SY_1_39 & R3 & 19 & 54 & 48.2 & 3.6 & 2.5 & $<\mathrm{LOD}$ & 9.8 \\
\hline SY_1_39 & $\mathrm{R} 4$ & 15.6 & 40.4 & 37.8 & 4.2 & $<\mathrm{LOD}$ & $<\mathrm{LOD}$ & 9.7 \\
\hline SY_1_39 & $\mathrm{R} 5$ & 11.7 & 33.2 & 34.4 & $<\mathrm{LOD}$ & $<\mathrm{LOD}$ & $<\mathrm{LOD}$ & 8.5 \\
\hline SY_1_39 & $\mathrm{R} 7$ & 19.1 & 40.6 & 40.1 & 3.3 & $<\mathrm{LOD}$ & $<\mathrm{LOD}$ & 10 \\
\hline SY_1_53 & $\mathrm{R} 1$ & 25 & 79 & 68.1 & 7 & $<\mathrm{LOD}$ & 4.8 & 11.8 \\
\hline SY_1_53 & $\mathrm{R} 2$ & 17.4 & 67 & 47.5 & 5.1 & $<\mathrm{LOD}$ & $<\mathrm{LOD}$ & 12.1 \\
\hline SY_1_53 & R3 & 18 & 75 & 54.6 & 4.7 & $<\mathrm{LOD}$ & $<\mathrm{LOD}$ & 11.5 \\
\hline SY_1_53 & $\mathrm{R} 4$ & 17.3 & 57 & 51.5 & 7.2 & $<\mathrm{LOD}$ & 3.9 & 10.8 \\
\hline SY_1_53 & R5 & 23 & 102 & 70.2 & 7.8 & 2.6 & 5 & 13 \\
\hline SY_1_53 & R6 & 17 & 55 & 48.6 & 4.8 & $<\mathrm{LOD}$ & $<\mathrm{LOD}$ & 11.2 \\
\hline SA_1_11D & $\mathrm{R} 1$ & 25 & 34.4 & 74 & 7.7 & $<\mathrm{LOD}$ & 5.5 & 24.3 \\
\hline SA_1_11D & $\mathrm{R} 2$ & 27 & 39 & 77.2 & 8.5 & $<\mathrm{LOD}$ & 4.7 & 24.7 \\
\hline SA_1_11D & $\mathrm{R} 3$ & 26 & 42 & 77.1 & 8.5 & $<\mathrm{LOD}$ & 3.6 & 24.9 \\
\hline SA_1_11D & $\mathrm{R} 4$ & 26 & 39 & 70.7 & 9.6 & $<\mathrm{LOD}$ & 3.7 & 23 \\
\hline SA_1_11D & $\mathrm{R} 5$ & 24 & 36 & 77.3 & 8.7 & $<\mathrm{LOD}$ & 5.9 & 24.7 \\
\hline SA_1_11D & R6 & 27 & 41 & 82.4 & 11 & 2.3 & 4.7 & 21.3 \\
\hline SA_1_11U & $\mathrm{R} 1$ & 29 & 37 & 83.1 & 9 & $<\mathrm{LOD}$ & 4.8 & 30.5 \\
\hline SA_1_11U & $\mathrm{R} 2$ & 24 & 33 & 78.4 & 7.2 & $<\mathrm{LOD}$ & 4.9 & 30 \\
\hline SA_1_11U & R3 & 30 & 40 & 79.9 & 8.1 & $<\mathrm{LOD}$ & 4.7 & 30.4 \\
\hline SA_1_11U & $\mathrm{R} 4$ & 29 & 39 & 84.5 & 10.3 & $<\mathrm{LOD}$ & 4.5 & 30 \\
\hline SA_1_11U & $\mathrm{R} 5$ & 26 & 37 & 82.2 & 11.6 & $<\mathrm{LOD}$ & 4.3 & 27.9 \\
\hline SA_1_11U & R6 & 28 & 40 & 83.7 & 9.7 & $<\mathrm{LOD}$ & 5.3 & 30 \\
\hline SA_1_38D & $\mathrm{R} 1$ & 23 & 56 & 65.8 & 5.2 & $<\mathrm{LOD}$ & 3.9 & 13.8 \\
\hline SA_1_38D & $\mathrm{R} 2$ & 23 & 40.9 & 59.2 & 4.6 & $<\mathrm{LOD}$ & 3 & 13.5 \\
\hline SA_1_38D & $\mathrm{R} 3$ & 22 & 30.5 & 55.5 & 6.4 & $<\mathrm{LOD}$ & $<\mathrm{LOD}$ & 10.2 \\
\hline SA_1_38D & $\mathrm{R} 4$ & 25 & 38.4 & 53.4 & 6.2 & $<\mathrm{LOD}$ & $<\mathrm{LOD}$ & 9 \\
\hline SA_1_38D & R5 & 23 & 33.1 & 66.1 & 5.2 & $<\mathrm{LOD}$ & $<\mathrm{LOD}$ & 11 \\
\hline SA_1_38D & R6 & 20.6 & 31.6 & 48.8 & 5.5 & $<\mathrm{LOD}$ & 3.9 & 9.4 \\
\hline SA_1_38U & $\mathrm{R} 1$ & 27 & 37.5 & 64.1 & 10.4 & $<\mathrm{LOD}$ & 3.5 & 15.9 \\
\hline SA_1_38U & $\mathrm{R} 2$ & 27 & 20.3 & 42.5 & 6.7 & $<\mathrm{LOD}$ & 3.6 & 14.4 \\
\hline SA_1_38U & $\mathrm{R} 3$ & 26 & 26.9 & 57.7 & 9 & $<\mathrm{LOD}$ & 4.1 & 14.3 \\
\hline SA_1_38U & $\mathrm{R} 4$ & 25 & 18.1 & 48.5 & 6.4 & $<\mathrm{LOD}$ & 3.2 & 14.1 \\
\hline SA_1_38U & $\mathrm{R} 5$ & 23 & 22.3 & 50.4 & 6.2 & $<\mathrm{LOD}$ & 3.4 & 15.6 \\
\hline SA_1_38U & R6 & 22 & 22.2 & 48.9 & 7.2 & $<\mathrm{LOD}$ & 5.3 & 15.6 \\
\hline SA_1_41.3D & $\mathrm{R} 1$ & 22 & 30.9 & 76.9 & 3.9 & $<\mathrm{LOD}$ & 3.2 & 15.6 \\
\hline SA_1_41.3D & $\mathrm{R} 2$ & 35 & 36 & 94 & 4.6 & $<\mathrm{LOD}$ & 6.3 & 13.8 \\
\hline SA_1_41.3D & R3 & 27 & 26.5 & 78.4 & 5.1 & $<\mathrm{LOD}$ & $<\mathrm{LOD}$ & 13.3 \\
\hline SA_1_41.3D & $\mathrm{R} 4$ & 23 & 24 & 61.1 & 4.2 & $<\mathrm{LOD}$ & 2.9 & 14.5 \\
\hline SA_1_41.3D & R5 & 23 & 23.1 & 60 & 5.2 & $<\mathrm{LOD}$ & $<\mathrm{LOD}$ & 10.6 \\
\hline SA_1_41.3D & R6 & 22 & 26.2 & 69.6 & 4.3 & $<\mathrm{LOD}$ & $<\mathrm{LOD}$ & 13.2 \\
\hline
\end{tabular}




\begin{tabular}{|c|c|c|c|c|c|c|c|c|}
\hline SA_1_43 & $\mathrm{R} 1$ & 15.3 & 27.2 & 37.6 & 2.6 & $<\mathrm{LOD}$ & $<\mathrm{LOD}$ & 10.8 \\
\hline SA_1_43 & $\mathrm{R} 2$ & 21 & 39.6 & 55.7 & 4.6 & $<\mathrm{LOD}$ & 4.1 & 12.4 \\
\hline SA_1_43 & R3 & 14.8 & 25.1 & 35.1 & 2.5 & $<\mathrm{LOD}$ & $<\mathrm{LOD}$ & 11.6 \\
\hline SA_1_43 & $\mathrm{R} 4$ & 19.8 & 29.9 & 45 & 3.5 & $<\mathrm{LOD}$ & 3.2 & 10.1 \\
\hline SA_1_43 & R5 & 20 & 27.9 & 44.8 & 4.4 & $<\mathrm{LOD}$ & $<\mathrm{LOD}$ & 9.7 \\
\hline SA_1_43 & R6 & 15.5 & 26.1 & 40.2 & 4.5 & $<\mathrm{LOD}$ & 3.1 & 8.9 \\
\hline SA_1_13.5 & $\mathrm{R} 1$ & 22 & 44 & 104 & 9.7 & $<\mathrm{LOD}$ & 4.9 & 22.9 \\
\hline SA_1_13.5 & $\mathrm{R} 2$ & 28 & 36.6 & 104 & 12.2 & $<\mathrm{LOD}$ & 3.8 & 20.2 \\
\hline SA_1_13.5 & R3 & 23 & 40 & 104 & 10.8 & $<\mathrm{LOD}$ & 3.8 & 20.3 \\
\hline SA_1_13.5 & R4 & 29 & 38 & 104 & 10.2 & $<\mathrm{LOD}$ & 4.5 & 21.1 \\
\hline SA_1_13.5 & R5 & 24 & 44 & 108 & 13.1 & $<\mathrm{LOD}$ & $<$ LOD & 20.3 \\
\hline SA_1_13.5 & R6 & 34 & 43 & 108 & 9.8 & $<\mathrm{LOD}$ & 5.5 & 21.2 \\
\hline SA_1_15 & $\mathrm{R} 1$ & 23 & 30.1 & 75.8 & 9.4 & $<\mathrm{LOD}$ & 5.9 & 25.9 \\
\hline SA_1_15 & $\mathrm{R} 2$ & 25 & 34.4 & 80.1 & 9.7 & $<\mathrm{LOD}$ & 6.2 & 27.1 \\
\hline SA_1_15 & R3 & 27 & 31.1 & 75.7 & 11.1 & $<\mathrm{LOD}$ & $<\mathrm{LOD}$ & 23.2 \\
\hline SA_1_15 & $\mathrm{R} 4$ & 28 & 33.4 & 83 & 10.7 & $<\mathrm{LOD}$ & 4.8 & 26.3 \\
\hline SA_1_15 & R5 & 29 & 25 & 77.6 & 9.8 & $<\mathrm{LOD}$ & 4.3 & 22.1 \\
\hline SA_1_15 & R6 & 25 & 31.4 & 76.5 & 9.2 & $<\mathrm{LOD}$ & 4.8 & 24.9 \\
\hline SA_1_15.7 & $\mathrm{R} 1$ & 36 & 52 & 115 & 12.9 & $<\mathrm{LOD}$ & 5.2 & 23.6 \\
\hline SA_1_15.7 & $\mathrm{R} 2$ & 33 & 42 & 107 & 12.8 & $<\mathrm{LOD}$ & 4.1 & 24.2 \\
\hline SA_1_15.7 & R3 & 29 & 55 & 112 & 12.1 & $<\mathrm{LOD}$ & 6 & 27.2 \\
\hline SA_1_15.7 & $\mathrm{R} 4$ & 33 & 42 & 102 & 14 & $<\mathrm{LOD}$ & 5.1 & 21.6 \\
\hline SA_1_15.7 & R5 & 35 & 47 & 111 & 12.6 & $<\mathrm{LOD}$ & 5.6 & 26.2 \\
\hline SA_1_15.7 & R6 & 36 & 41 & 105 & 12.1 & $<\mathrm{LOD}$ & 5.3 & 27.2 \\
\hline SA_1_16.7 & $\mathrm{R} 1$ & 25 & 65 & 146 & 7.3 & $<\mathrm{LOD}$ & 3.1 & 18.7 \\
\hline SA_1_16.7 & $\mathrm{R} 2$ & 26 & 44 & 139 & 7.8 & $<\mathrm{LOD}$ & 3.6 & 17.9 \\
\hline SA_1_16.7 & R3 & 28 & 40 & 129 & 8 & $<\mathrm{LOD}$ & $<\mathrm{LOD}$ & 18.5 \\
\hline SA_1_16.7 & $\mathrm{R} 4$ & 22 & 44 & 130 & 6.8 & $<\mathrm{LOD}$ & 4.4 & 18 \\
\hline SA_1_16.7 & R5 & 21 & 42 & 131 & 8.7 & $<\mathrm{LOD}$ & $<\mathrm{LOD}$ & 16.3 \\
\hline SA_1_16.7 & R6 & 33 & 50 & 156 & 7.6 & $<\mathrm{LOD}$ & $<\mathrm{LOD}$ & 19.1 \\
\hline SA_1_21 & $\mathrm{R} 1$ & 21 & 37.6 & 51.9 & 2.7 & $<\mathrm{LOD}$ & $<\mathrm{LOD}$ & 9.6 \\
\hline SA_1_21 & $\mathrm{R} 2$ & 21 & 30.6 & 40.4 & 5 & $<\mathrm{LOD}$ & $<\mathrm{LOD}$ & 4.8 \\
\hline SA_1_21 & R3 & 18 & 28.2 & 37.9 & 3.2 & $<\mathrm{LOD}$ & $<\mathrm{LOD}$ & 8.1 \\
\hline SA_1_21 & $\mathrm{R} 4$ & 23 & 27.3 & 37.9 & 2.4 & $<\mathrm{LOD}$ & $<\mathrm{LOD}$ & 9.8 \\
\hline SA_1_21 & R5 & 22 & 36.1 & 46.4 & 5.5 & $<\mathrm{LOD}$ & 3.4 & 10.7 \\
\hline SA_1_21 & R6 & 23 & 89 & 79.1 & 6.6 & $<\mathrm{LOD}$ & 3.2 & 15.9 \\
\hline SA_1_21.2 & $\mathrm{R} 1$ & 11.5 & 31.8 & 31.9 & 4.1 & $<\mathrm{LOD}$ & $<$ LOD & 7 \\
\hline SA_1_21.2 & $\mathrm{R} 2$ & 12.3 & 21.4 & 28 & $<\mathrm{LOD}$ & $<\mathrm{LOD}$ & $<\mathrm{LOD}$ & 9.2 \\
\hline SA_1_21.2 & $\mathrm{R} 3$ & 13.7 & 32.9 & 38.3 & 3.2 & $<\mathrm{LOD}$ & $<\mathrm{LOD}$ & 9 \\
\hline SA_1_21.2 & $\mathrm{R} 4$ & 11.7 & 26.6 & 32.9 & 2.6 & $<\mathrm{LOD}$ & 3.8 & 8.6 \\
\hline SA_1_21.2 & R5 & 12.7 & 24.2 & 26.2 & 2.2 & $<\mathrm{LOD}$ & $<\mathrm{LOD}$ & 8.6 \\
\hline SA_1_21.2 & R6 & 10.3 & 25 & 30.9 & 2.4 & $<\mathrm{LOD}$ & $<\mathrm{LOD}$ & 8.2 \\
\hline
\end{tabular}




\begin{tabular}{|c|c|c|c|c|c|c|c|c|}
\hline SA_1_25 & $\mathrm{R} 1$ & 15 & 25.7 & 29.7 & $<$ LOD & $<$ LOD & 3.2 & 7.9 \\
\hline SA_1_25 & $\mathrm{R} 2$ & 10.4 & 18.3 & 26.4 & $<\mathrm{LOD}$ & $<\mathrm{LOD}$ & $<\mathrm{LOD}$ & 7.3 \\
\hline SA_1_25 & R3 & 16 & 28.3 & 37.5 & $<\mathrm{LOD}$ & $<\mathrm{LOD}$ & $<\mathrm{LOD}$ & 8.9 \\
\hline SA_1_25 & $\mathrm{R} 4$ & 12.8 & 20.1 & 29.1 & 2.3 & $<\mathrm{LOD}$ & 3.2 & 6.6 \\
\hline SA_1_25 & R5 & 12.7 & 27.2 & 31.1 & 2.3 & $<\mathrm{LOD}$ & 3.1 & 6.3 \\
\hline SA_1_25 & R6 & 13.2 & 20.9 & 30.8 & 2.5 & $<\mathrm{LOD}$ & 3.9 & 9.3 \\
\hline SA_1_30 & $\mathrm{R} 1$ & 17.2 & 19.7 & 47.7 & 4.1 & $<\mathrm{LOD}$ & $<\mathrm{LOD}$ & 11.7 \\
\hline SA_1_30 & $\mathrm{R} 2$ & 13.4 & 25.1 & 43.6 & 2.6 & $<\mathrm{LOD}$ & $<\mathrm{LOD}$ & 10.2 \\
\hline SA_1_30 & R3 & 17.8 & 22.9 & 43.1 & 2.8 & $<\mathrm{LOD}$ & 2.7 & 10.3 \\
\hline SA_1_30 & R4 & 11.2 & 25.4 & 53.5 & 2.9 & $<\mathrm{LOD}$ & 4.3 & 10.5 \\
\hline SA_1_30 & R5 & 13.8 & 18.7 & 47.5 & $<\mathrm{LOD}$ & $<\mathrm{LOD}$ & $<$ LOD & 10.7 \\
\hline SA_1_30 & R6 & 12 & 22.5 & 43.8 & 2.6 & $<\mathrm{LOD}$ & 3.2 & 9 \\
\hline SA_1_36.6 & $\mathrm{R} 1$ & 14.8 & 40.6 & 38.2 & 2.4 & $<\mathrm{LOD}$ & $<\mathrm{LOD}$ & 12.1 \\
\hline SA_1_36.6 & $\mathrm{R} 2$ & 22 & 41.5 & 45.3 & 4.4 & $<\mathrm{LOD}$ & 3.1 & 10.8 \\
\hline SA_1_36.6 & R3 & 18.7 & 32.5 & 35.4 & 2.7 & $<\mathrm{LOD}$ & $<\mathrm{LOD}$ & 13.6 \\
\hline SA_1_36.6 & $\mathrm{R} 4$ & 25 & 61 & 62.1 & $<\mathrm{LOD}$ & $<\mathrm{LOD}$ & 3.3 & 16.7 \\
\hline SA_1_36.6 & R5 & 19 & 58 & 53.4 & 4.1 & $<\mathrm{LOD}$ & $<\mathrm{LOD}$ & 13.9 \\
\hline SA_1_36.6 & R6 & 16.5 & 38.3 & 44 & 4.3 & $<\mathrm{LOD}$ & $<\mathrm{LOD}$ & 11.1 \\
\hline SA_1_43 & $\mathrm{R} 1$ & 38 & 35.1 & 69.3 & 6.7 & $<\mathrm{LOD}$ & $<\mathrm{LOD}$ & 15.2 \\
\hline SA_1_43 & $\mathrm{R} 2$ & 17.4 & 31.4 & 53.4 & 4.6 & $<\mathrm{LOD}$ & 3.7 & 13 \\
\hline SA_1_43 & R3 & 21 & 39.2 & 74.3 & 5.8 & $<\mathrm{LOD}$ & 3 & 15.1 \\
\hline SA_1_43 & R4 & 24 & 28.9 & 74.9 & 5.3 & $<\mathrm{LOD}$ & 3 & 15.8 \\
\hline SA_1_43 & R5 & 25 & 32.1 & 62.4 & 5.9 & $<\mathrm{LOD}$ & 3.3 & 12.8 \\
\hline SA_1_43 & R6 & 25 & 35.2 & 70.2 & 5.2 & $<\mathrm{LOD}$ & 4.1 & 15.4 \\
\hline SA_1_46.2 & $\mathrm{R} 1$ & 26 & 68 & 241 & 10.1 & $<\mathrm{LOD}$ & $<\mathrm{LOD}$ & 27 \\
\hline SA_1_46.2 & $\mathrm{R} 2$ & 28 & 85 & 230 & 8.5 & $<\mathrm{LOD}$ & 4.4 & 25.6 \\
\hline SA_1_46.2 & R3 & 32 & 80 & 232 & 9.5 & $<\mathrm{LOD}$ & $<\mathrm{LOD}$ & 25.9 \\
\hline SA_1_46.2 & $\mathrm{R} 4$ & 28 & 74 & 242 & 10.2 & $<\mathrm{LOD}$ & $<\mathrm{LOD}$ & 27.6 \\
\hline SA_1_46.2 & R5 & 29 & 88 & 238 & 10 & $<\mathrm{LOD}$ & 4.2 & 25.7 \\
\hline SA_1_46.2 & R6 & 26 & 84 & 231 & 10.9 & $<\mathrm{LOD}$ & $<\mathrm{LOD}$ & 24 \\
\hline CA_2_.5 & $\mathrm{R} 1$ & 15.7 & 46.5 & 32.6 & 2.3 & $<\mathrm{LOD}$ & $<\mathrm{LOD}$ & 8.6 \\
\hline CA_2_.5 & $\mathrm{R} 2$ & 10.7 & 35.2 & 30.7 & 2.2 & $<\mathrm{LOD}$ & $<\mathrm{LOD}$ & 8.2 \\
\hline CA_2_.5 & R3 & 16.3 & 40.1 & 37.4 & $<\mathrm{LOD}$ & $<\mathrm{LOD}$ & 3.4 & 8.3 \\
\hline CA_2_.5 & $\mathrm{R} 4$ & 13.3 & 52 & 34.8 & 2.5 & $<\mathrm{LOD}$ & $<\mathrm{LOD}$ & 8.9 \\
\hline CA_2_.5 & R5 & 16.6 & 62 & 44.9 & 2.9 & $<\mathrm{LOD}$ & $<\mathrm{LOD}$ & 8.4 \\
\hline CA_2_.5 & R6 & 14.6 & 49.1 & 38.9 & 2.4 & $<\mathrm{LOD}$ & 2.7 & 6.7 \\
\hline CA_2_2 & $\mathrm{R} 1$ & 21 & 85 & 74.1 & 3.6 & $<\mathrm{LOD}$ & $<$ LOD & 13.3 \\
\hline CA_2_2 & $\mathrm{R} 2$ & 20.4 & 53 & 50.7 & 4 & $<\mathrm{LOD}$ & 4.3 & 7.9 \\
\hline CA_2_2 & R3 & 10.2 & 39.2 & 38.4 & 2.5 & $<\mathrm{LOD}$ & 3.5 & 7.8 \\
\hline CA_2_2 & R4 & 14.2 & 37.9 & 37.6 & 2.5 & $<\mathrm{LOD}$ & 3.4 & 8.8 \\
\hline CA_2_2 & R5 & 13.8 & 33.1 & 41.9 & 3.2 & 2.7 & $<\mathrm{LOD}$ & 8 \\
\hline CA_2_2 & R6 & 16.4 & 45.7 & 50.5 & 4.4 & $<\mathrm{LOD}$ & $<\mathrm{LOD}$ & 7.5 \\
\hline
\end{tabular}




\begin{tabular}{|c|c|c|c|c|c|c|c|c|}
\hline CA_2_5 & $\mathrm{R} 1$ & 17.3 & 44.1 & 45.2 & 3.1 & $<\mathrm{LOD}$ & $<$ LOD & 7.7 \\
\hline CA_2_5 & $\mathrm{R} 2$ & 33 & 79 & 54.8 & 3.2 & $<\mathrm{LOD}$ & $<\mathrm{LOD}$ & 9.9 \\
\hline CA_2_5 & R3 & 13.7 & 43.6 & 36 & $<\mathrm{LOD}$ & $<\mathrm{LOD}$ & $<\mathrm{LOD}$ & 8.7 \\
\hline CA_2_5 & $\mathrm{R} 4$ & 16.2 & 52 & 41.2 & $<\mathrm{LOD}$ & $<\mathrm{LOD}$ & $<\mathrm{LOD}$ & 9.6 \\
\hline CA_2_5 & $\mathrm{R} 5$ & 14.6 & 43.2 & 38.3 & $<\mathrm{LOD}$ & $<\mathrm{LOD}$ & $<\mathrm{LOD}$ & 9.4 \\
\hline CA_2_5 & R6 & 13.5 & 41.2 & 35.3 & 5.2 & $<\mathrm{LOD}$ & 3.8 & 5.1 \\
\hline CA_2_10 & $\mathrm{R} 1$ & 39 & 47 & 85.7 & 10.2 & $<\mathrm{LOD}$ & 5.2 & 22.6 \\
\hline CA_2_10 & $\mathrm{R} 2$ & 24 & 36 & 76.6 & 8.3 & $<\mathrm{LOD}$ & $<\mathrm{LOD}$ & 20.3 \\
\hline CA_2_10 & R3 & 44 & 38 & 82.8 & 8.4 & $<\mathrm{LOD}$ & 4.7 & 21.6 \\
\hline CA_2_10 & $\mathrm{R} 4$ & 34 & 41 & 82.8 & 6.7 & $<\mathrm{LOD}$ & 3.4 & 24.2 \\
\hline CA_2_10 & R5 & 29 & 40 & 81.5 & 6.7 & $<\mathrm{LOD}$ & 3.6 & 20.2 \\
\hline CA_2_10 & R6 & 24 & 41 & 79.4 & 9.1 & $<\mathrm{LOD}$ & 3.7 & 20.5 \\
\hline CA_2_11 & $\mathrm{R} 1$ & 31 & 60 & 152 & 8.1 & $<\mathrm{LOD}$ & 3.8 & 26.1 \\
\hline CA_2_11 & $\mathrm{R} 2$ & 40 & 52 & 171 & 9.6 & $<\mathrm{LOD}$ & 4.6 & 28.3 \\
\hline CA_2_11 & $\mathrm{R} 3$ & 32 & 71 & 158 & 9.4 & $<\mathrm{LOD}$ & 3.3 & 26.7 \\
\hline CA_2_11 & $\mathrm{R} 4$ & 34 & 57 & 167 & 9.7 & 2.5 & 3.6 & 28.4 \\
\hline CA_2_11 & R5 & 39 & 64 & 157 & 11.7 & $<\mathrm{LOD}$ & 4.8 & 23.8 \\
\hline CA_2_11 & R6 & 32 & 54 & 170 & 11.3 & $<\mathrm{LOD}$ & 4.3 & 24.2 \\
\hline CA_1_18.5 & $\mathrm{R} 1$ & 33 & 40 & 124 & 7.2 & $<\mathrm{LOD}$ & 4.2 & 20.8 \\
\hline CA_1_18.5 & $\mathrm{R} 2$ & 31 & 37.7 & 128 & 8.2 & $<\mathrm{LOD}$ & 3.1 & 19.4 \\
\hline CA_1_18.5 & R3 & 26 & 42 & 134 & 9.3 & $<\mathrm{LOD}$ & 4.4 & 20.9 \\
\hline CA_1_18.5 & $\mathrm{R} 4$ & 30 & 49 & 160 & 10 & 2.3 & 3.8 & 22.2 \\
\hline CA_1_18.5 & $\mathrm{R} 5$ & 34 & 40 & 120 & 7.2 & $<\mathrm{LOD}$ & 5.9 & 21.7 \\
\hline CA_1_18.5 & R6 & 28 & 38.2 & 138 & 8.6 & $<\mathrm{LOD}$ & $<\mathrm{LOD}$ & 22.2 \\
\hline CA_1_22 & $\mathrm{R} 1$ & 23.3 & 36.8 & 49.7 & 3.4 & $<\mathrm{LOD}$ & 2.8 & 9 \\
\hline CA_1_22 & $\mathrm{R} 2$ & 16.5 & 27.1 & 44 & 2.7 & $<\mathrm{LOD}$ & 3.7 & 8.4 \\
\hline CA_1_22 & R3 & 15.3 & 37.6 & 52.9 & 3.5 & $<\mathrm{LOD}$ & $<\mathrm{LOD}$ & 9.3 \\
\hline CA_1_22 & $\mathrm{R} 4$ & 103 & 32 & 44 & $<\mathrm{LOD}$ & $<\mathrm{LOD}$ & 3.7 & 8.4 \\
\hline CA_1_22 & R5 & 11.6 & 28.2 & 40.4 & 3.7 & $<\mathrm{LOD}$ & $<\mathrm{LOD}$ & 6.7 \\
\hline CA_1_22 & R6 & 21 & 33.3 & 45.6 & 3.6 & $<\mathrm{LOD}$ & $<$ LOD & 8.8 \\
\hline CA_1_25.5 & $\mathrm{R} 1$ & 40 & 62 & 81.7 & 6.3 & $<\mathrm{LOD}$ & 3.8 & 11.3 \\
\hline CA_1_25.5 & $\mathrm{R} 2$ & 13.5 & 27.6 & 45.9 & 3.2 & $<\mathrm{LOD}$ & $<\mathrm{LOD}$ & 10.1 \\
\hline CA_1_25.5 & $\mathrm{R} 3$ & 14.6 & 32.2 & 61.1 & 4.1 & $<\mathrm{LOD}$ & $<\mathrm{LOD}$ & 11.8 \\
\hline CA_1_25.5 & $\mathrm{R} 4$ & 21 & 50 & 67.2 & 4.3 & $<\mathrm{LOD}$ & 4.8 & 13.3 \\
\hline CA_1_25.5 & $\mathrm{R} 5$ & 20.1 & 33.3 & 51.5 & 3.9 & $<\mathrm{LOD}$ & 3.7 & 9.2 \\
\hline CA_1_25.5 & R6 & 19 & 39.6 & 60.5 & 4.2 & $<\mathrm{LOD}$ & 3.3 & 13.3 \\
\hline CA_1_28 & $\mathrm{R} 1$ & 25 & 50 & 115 & 8.3 & $<\mathrm{LOD}$ & 5.8 & 21.1 \\
\hline CA_1_28 & $\mathrm{R} 2$ & 29 & 46 & 106 & 7.6 & $<\mathrm{LOD}$ & 3.1 & 20.8 \\
\hline CA_1_28 & R3 & 27 & 47 & 104.4 & 7.4 & $<\mathrm{LOD}$ & 4 & 21.5 \\
\hline CA_1_28 & $\mathrm{R} 4$ & 30 & 64 & 120 & 7.7 & $<\mathrm{LOD}$ & 3.1 & 25.3 \\
\hline CA_1_28 & R5 & 26 & 54 & 112 & 8.3 & $<\mathrm{LOD}$ & 4.7 & 20.2 \\
\hline CA_1_28 & R6 & 32 & 60 & 119 & 8.5 & $<\mathrm{LOD}$ & $<\mathrm{LOD}$ & 20.6 \\
\hline
\end{tabular}




\begin{tabular}{|c|c|c|c|c|c|c|c|c|}
\hline CA_1_35.5 & $\mathrm{R} 1$ & 27 & 70 & 215 & 7.5 & $<\mathrm{LOD}$ & 3.2 & 25.8 \\
\hline CA_1_35.5 & $\mathrm{R} 2$ & 31 & 68 & 213 & 6 & $<\mathrm{LOD}$ & 3.3 & 29.2 \\
\hline CA_1_35.5 & $\mathrm{R} 3$ & 34 & 67 & 218 & 10.5 & $<\mathrm{LOD}$ & 6.2 & 23.2 \\
\hline CA_1_35.5 & $\mathrm{R} 4$ & 27 & 63 & 202 & 8.5 & $<\mathrm{LOD}$ & $<\mathrm{LOD}$ & 24.7 \\
\hline CA_1_35.5 & R5 & 33 & 66 & 213 & 8.1 & $<\mathrm{LOD}$ & 4.4 & 26 \\
\hline CA_1_35.5 & R6 & 28 & 68 & 209 & 7.8 & $<\mathrm{LOD}$ & 5.4 & 25.3 \\
\hline CA_1_35.5 & $\mathrm{R} 7$ & 28 & 69 & 233 & 8.9 & $<\mathrm{LOD}$ & 4.8 & 23.6 \\
\hline VC_1_5 & $\mathrm{R} 1$ & 27 & 82 & 143 & 6.1 & $<\mathrm{LOD}$ & $<\mathrm{LOD}$ & 18 \\
\hline VC_1_5 & $\mathrm{R} 2$ & & & & & & & \\
\hline VC_1_5 & R3 & 33 & 53 & 113 & 6.7 & $<\mathrm{LOD}$ & 4.3 & 13.7 \\
\hline VC_1_5 & $\mathrm{R} 4$ & 18 & 57 & 114 & 4.5 & $<\mathrm{LOD}$ & $<\mathrm{LOD}$ & 17.4 \\
\hline VC_1_5 & R5 & 33 & 71 & 132 & 8 & $<\mathrm{LOD}$ & 4 & 15.7 \\
\hline VC_1_5 & R6 & 27 & 67 & 117 & 5.9 & $<\mathrm{LOD}$ & 4.1 & 16.5 \\
\hline VC_1_5 & $\mathrm{R} 7$ & 44 & 73 & 129 & 9.3 & $<\mathrm{LOD}$ & 4.5 & 14.7 \\
\hline VC_1_13.7 & $\mathrm{R} 1$ & 23 & 110 & 85.2 & 3.3 & $<\mathrm{LOD}$ & 3 & 14.3 \\
\hline VC_1_13.7 & $\mathrm{R} 2$ & 16.5 & 53 & 53.8 & 2.7 & $<\mathrm{LOD}$ & $<\mathrm{LOD}$ & 9.7 \\
\hline VC_1_13.7 & $\mathrm{R} 3$ & 9.6 & 41.9 & 48.6 & 2.9 & $<\mathrm{LOD}$ & $<\mathrm{LOD}$ & 8.9 \\
\hline VC_1_13.7 & $\mathrm{R} 4$ & 18 & 61 & 68 & 3.2 & $<\mathrm{LOD}$ & $<\mathrm{LOD}$ & 11.1 \\
\hline VC_1_13.7 & R5 & 22 & 50 & 53.6 & $<\mathrm{LOD}$ & $<\mathrm{LOD}$ & $<\mathrm{LOD}$ & 11.5 \\
\hline VC_1_13.7 & R6 & 19 & 69 & 65.3 & $<\mathrm{LOD}$ & $<\mathrm{LOD}$ & $<\mathrm{LOD}$ & 11 \\
\hline VC_2_9 & $\mathrm{R} 1$ & 14.8 & 38.5 & 50.3 & 2.4 & $<\mathrm{LOD}$ & $<\mathrm{LOD}$ & 11.2 \\
\hline VC_2_9 & $\mathrm{R} 2$ & 22 & 32.8 & 50 & 2.6 & $<\mathrm{LOD}$ & 2.9 & 12.9 \\
\hline VC_2_9 & $\mathrm{R} 3$ & 14 & 39.9 & 49.8 & 3.5 & $<\mathrm{LOD}$ & 3.2 & 9.5 \\
\hline VC_2_9 & $\mathrm{R} 4$ & 11.5 & 34.5 & 44.3 & 2.6 & $<\mathrm{LOD}$ & 3.2 & 11.4 \\
\hline VC_2_9 & R5 & 24.5 & 36.6 & 45.8 & 3.3 & $<\mathrm{LOD}$ & 3.8 & 12.5 \\
\hline VC_2_9 & R6 & 17.9 & 42 & 49.7 & 3.7 & $<\mathrm{LOD}$ & 3.6 & 12.4 \\
\hline VC_2_26 & $\mathrm{R} 1$ & 29 & 66 & 90.6 & 7.5 & $<\mathrm{LOD}$ & 6.1 & 29.2 \\
\hline VC_2_26 & $\mathrm{R} 2$ & 40 & 57 & 86.7 & 5.1 & $<\mathrm{LOD}$ & 5 & 29.8 \\
\hline VC_2_26 & $\mathrm{R} 3$ & 39 & 72 & 89.2 & 8.5 & $<\mathrm{LOD}$ & 4.1 & 29.8 \\
\hline VC_2_26 & $\mathrm{R} 4$ & 34 & 63 & 88.8 & 7.1 & $<\mathrm{LOD}$ & 3.9 & 30.3 \\
\hline VC_2_26 & R5 & 33 & 64 & 89.8 & 7.8 & $<\mathrm{LOD}$ & 4.8 & 31.6 \\
\hline VC_2_26 & R6 & 35 & 63 & 91.4 & 7.4 & $<\mathrm{LOD}$ & 3.6 & 31.8 \\
\hline VC_1.5_15 & $\mathrm{R} 1$ & 23 & 40.7 & 58.7 & 4.6 & $<\mathrm{LOD}$ & 3.7 & 6.2 \\
\hline VC_1.5_15 & $\mathrm{R} 2$ & 13 & 273 & 58.7 & 3.8 & $<\mathrm{LOD}$ & $<\mathrm{LOD}$ & 11 \\
\hline VC_1.5_15 & $\mathrm{R} 3$ & 15 & 44.7 & 55 & 3.9 & $<\mathrm{LOD}$ & 2.8 & 9.6 \\
\hline VC_1.5_15 & $\mathrm{R} 4$ & 19 & 51 & 60.1 & 4.1 & $<\mathrm{LOD}$ & $<\mathrm{LOD}$ & 8.5 \\
\hline VC_1.5_15 & $\mathrm{R} 5$ & 10 & 38.6 & 57.5 & 3.4 & $<\mathrm{LOD}$ & $<\mathrm{LOD}$ & 8.1 \\
\hline VC_1.5_15 & R6 & 19 & 80 & 84.8 & 4.4 & $<\mathrm{LOD}$ & 3.6 & 13.5 \\
\hline
\end{tabular}




\begin{tabular}{|c|c|c|c|c|c|c|c|c|}
\hline VC_1.5_18 & $\mathrm{R} 1$ & 26 & 71 & 57.9 & $<$ LOD & $<\mathrm{LOD}$ & 4 & 10.8 \\
\hline VC_1.5_18 & $\mathrm{R} 2$ & 18 & 65 & 58.2 & 4.1 & $<\mathrm{LOD}$ & 3.4 & 7.3 \\
\hline VC_1.5_18 & R3 & 14 & 64 & 49.9 & 3.6 & $<\mathrm{LOD}$ & $<\mathrm{LOD}$ & 9.2 \\
\hline VC_1.5_18 & $\mathrm{R} 4$ & 17 & 51 & 59.2 & 3.2 & $<\mathrm{LOD}$ & $<\mathrm{LOD}$ & 8.6 \\
\hline VC_1.5_18 & $\mathrm{R} 5$ & 15 & 53 & 52.8 & 2.6 & $<\mathrm{LOD}$ & 4 & 9 \\
\hline VC_1.5_18 & R6 & 21 & 51 & 52.9 & 2.6 & $<\mathrm{LOD}$ & $<\mathrm{LOD}$ & 6.5 \\
\hline VC_1_18 & $\mathrm{R} 1$ & 21 & 44 & 89.2 & 7.1 & $<\mathrm{LOD}$ & $<\mathrm{LOD}$ & 17 \\
\hline VC_1_18 & $\mathrm{R} 2$ & 28 & 49 & 75.3 & 5.7 & $<\mathrm{LOD}$ & $<\mathrm{LOD}$ & 16.1 \\
\hline VC_1_18 & R3 & 30 & 47 & 78.6 & 5.9 & $<\mathrm{LOD}$ & $<\mathrm{LOD}$ & 17.8 \\
\hline VC_1_18 & $\mathrm{R} 4$ & 25 & 57 & 83.8 & 9.2 & $<\mathrm{LOD}$ & 3.5 & 15.5 \\
\hline VC_1_18 & R5 & 23 & 39.1 & 71.4 & 6.8 & $<\mathrm{LOD}$ & $<\mathrm{LOD}$ & 14.3 \\
\hline VC_1_18 & R6 & 23 & 44 & 73 & 5.4 & $<\mathrm{LOD}$ & 3.3 & 15.6 \\
\hline VC_1_28 & $\mathrm{R} 1$ & 16.3 & 66 & 55.4 & 5.3 & $<\mathrm{LOD}$ & 3.1 & 15.7 \\
\hline VC_1_28 & $\mathrm{R} 2$ & 15 & 55 & 42.4 & $<\mathrm{LOD}$ & $<\mathrm{LOD}$ & $<\mathrm{LOD}$ & 12.7 \\
\hline VC_1_28 & $\mathrm{R} 3$ & 14.8 & 52 & 45.5 & 4.5 & $<\mathrm{LOD}$ & 4.8 & 10.8 \\
\hline VC_1_28 & $\mathrm{R} 4$ & 14 & 56 & 58.2 & 5.5 & $<\mathrm{LOD}$ & 3.7 & 11.5 \\
\hline VC_1_28 & R5 & 20.3 & 72 & 53.5 & 3.9 & $<\mathrm{LOD}$ & $<\mathrm{LOD}$ & 11.7 \\
\hline VC_1_28 & R6 & 17.4 & 62 & 48.2 & $<\mathrm{LOD}$ & $<\mathrm{LOD}$ & $<\mathrm{LOD}$ & 14 \\
\hline SB_1_3.4 & $\mathrm{R} 1$ & 22 & 46 & 61.4 & 3.1 & $<\mathrm{LOD}$ & 3.1 & 10.6 \\
\hline SB_1_3.4 & $\mathrm{R} 2$ & 21 & 38.7 & 57.8 & 3.3 & $<\mathrm{LOD}$ & $<\mathrm{LOD}$ & 11.9 \\
\hline SB_1_3.4 & R3 & 24 & 45 & 60.8 & 5.2 & $<\mathrm{LOD}$ & $<\mathrm{LOD}$ & 8.7 \\
\hline SB_1_3.4 & $\mathrm{R} 4$ & 18 & 36.1 & 52.4 & 3.6 & $<\mathrm{LOD}$ & 3.4 & 10.4 \\
\hline SB_1_3.4 & $\mathrm{R} 5$ & 22 & 49 & 62.7 & 3.7 & $<\mathrm{LOD}$ & 5 & 11.2 \\
\hline SB_1_3.4 & R6 & 21 & 34.4 & 51.6 & 3.8 & $<\mathrm{LOD}$ & $<\mathrm{LOD}$ & 10.2 \\
\hline SB_1_10 & $\mathrm{R} 1$ & 21 & 51 & 150 & 4.3 & $<\mathrm{LOD}$ & 3.5 & 15.1 \\
\hline SB_1_10 & $\mathrm{R} 2$ & 26 & 50 & 147 & 3.9 & $<\mathrm{LOD}$ & $<\mathrm{LOD}$ & 14.6 \\
\hline SB_1_10 & $\mathrm{R} 3$ & 22 & 59 & 166 & 4.6 & $<\mathrm{LOD}$ & 3.8 & 14.5 \\
\hline SB_1_10 & $\mathrm{R} 4$ & 17 & 58 & 439 & 4.6 & $<\mathrm{LOD}$ & 2.9 & 15.1 \\
\hline SB_1_10 & $\mathrm{R} 5$ & 21 & 61 & 184 & 3.9 & $<\mathrm{LOD}$ & 4 & 15.4 \\
\hline SB_1_10 & R6 & 25 & 53 & 150 & 2.6 & $<\mathrm{LOD}$ & 4.3 & 17.4 \\
\hline SB_1_13 & $\mathrm{R} 1$ & 9.7 & 64 & 41.4 & $<\mathrm{LOD}$ & $<\mathrm{LOD}$ & 3.5 & 7.1 \\
\hline SB_1_13 & $\mathrm{R} 2$ & 7.6 & 52 & 39.1 & 2.5 & 2.6 & 4.1 & 7.3 \\
\hline SB_1_13 & $\mathrm{R} 3$ & 12.5 & 47.4 & 33 & $<\mathrm{LOD}$ & $<\mathrm{LOD}$ & $<\mathrm{LOD}$ & 9.1 \\
\hline SB_1_13 & $\mathrm{R} 4$ & 7 & 40.6 & 28.3 & $<\mathrm{LOD}$ & $<\mathrm{LOD}$ & $<\mathrm{LOD}$ & 7.6 \\
\hline SB_1_13 & $\mathrm{R} 5$ & 8.3 & 51.5 & 29.5 & $<\mathrm{LOD}$ & $<\mathrm{LOD}$ & 2.7 & 6.7 \\
\hline SB_1_13 & R6 & 12.1 & 40.8 & 30.1 & $<\mathrm{LOD}$ & $<\mathrm{LOD}$ & 4.2 & 9.2 \\
\hline SB_1_13-4D & $\mathrm{R} 1$ & 13.1 & 59 & 45.7 & 3.6 & $<\mathrm{LOD}$ & 3.1 & 6.7 \\
\hline SB_1_13-4D & $\mathrm{R} 2$ & 14.4 & 52 & 43.2 & 3.4 & $<\mathrm{LOD}$ & $<\mathrm{LOD}$ & 5.5 \\
\hline SB_1_13-4D & R3 & 10.9 & 50 & 42.6 & $<\mathrm{LOD}$ & $<\mathrm{LOD}$ & $<\mathrm{LOD}$ & 8 \\
\hline SB_1_13-4D & $\mathrm{R} 4$ & 25 & 94 & 78.8 & 5.5 & $<\mathrm{LOD}$ & $<\mathrm{LOD}$ & 6.7 \\
\hline SB_1_13-4D & $\mathrm{R} 5$ & 14 & 69 & 57.4 & 2.6 & $<\mathrm{LOD}$ & 2.8 & 8 \\
\hline SB_1_13-4D & R6 & 13 & 66 & 51.2 & 4.8 & $<\mathrm{LOD}$ & 4 & 7 \\
\hline
\end{tabular}




\begin{tabular}{|c|c|c|c|c|c|c|c|c|}
\hline SB_1_13-3.5U & $\mathrm{R} 1$ & 22 & 65 & 119 & 4.4 & $<\mathrm{LOD}$ & 4.3 & 20.6 \\
\hline SB_1_13-3.5U & $\mathrm{R} 2$ & 26 & 90 & 152 & 7.2 & $<\mathrm{LOD}$ & 4.6 & 23.3 \\
\hline SB_1_13-3.5U & R3 & 27 & 79 & 134 & 5.6 & $<\mathrm{LOD}$ & 4.7 & 68.8 \\
\hline SB_1_13-3.5U & $\mathrm{R} 4$ & 23 & 90 & 159 & 6.6 & $<\mathrm{LOD}$ & 3.5 & 24.6 \\
\hline SB_1_13-3.5U & R5 & 26 & 92 & 146 & 6.9 & $<\mathrm{LOD}$ & 5.3 & 22.9 \\
\hline $\mathrm{SB} \_1 \_13-3.5 \mathrm{U}$ & R6 & 23 & 72 & 126 & 6.3 & $<\mathrm{LOD}$ & 3 & 17.8 \\
\hline SB_1_13-3.5U & R7 & 31 & 98 & 159 & 7.6 & $<\mathrm{LOD}$ & 3.7 & 35 \\
\hline SB_1_14 & $\mathrm{R} 1$ & 13.5 & 66 & 47.8 & 3.2 & $<\mathrm{LOD}$ & 2.9 & 8.6 \\
\hline SB_1_14 & $\mathrm{R} 2$ & 15.1 & 59 & 38.9 & 2.3 & $<\mathrm{LOD}$ & 2.8 & 8.4 \\
\hline SB_1_14 & R3 & 10.8 & 51 & 41.9 & 2.5 & $<\mathrm{LOD}$ & 3.2 & 8.6 \\
\hline SB_1_14 & R4 & 11.8 & 51.1 & 40.3 & 2.3 & $<\mathrm{LOD}$ & $<\mathrm{LOD}$ & 6.3 \\
\hline SB_1_14 & R5 & 12.7 & 51.9 & 36.2 & 2.7 & $<\mathrm{LOD}$ & $<\mathrm{LOD}$ & 5.1 \\
\hline SB_1_14 & R6 & 12.5 & 49 & 35.1 & $<\mathrm{LOD}$ & $<\mathrm{LOD}$ & $<$ LOD & 9.5 \\
\hline SB_1_15 & $\mathrm{R} 1$ & 17 & 47 & 52.1 & $<\mathrm{LOD}$ & $<\mathrm{LOD}$ & 3.7 & 13 \\
\hline SB_1_15 & $\mathrm{R} 2$ & 16.1 & 43.6 & 45.3 & 2.8 & $<\mathrm{LOD}$ & 4.8 & 8.9 \\
\hline SB_1_15 & R3 & 13 & 49 & 56.6 & $<\mathrm{LOD}$ & $<\mathrm{LOD}$ & 4.2 & 12.2 \\
\hline SB_1_15 & $\mathrm{R} 4$ & 7.8 & 39.1 & 44.1 & 2.5 & $<\mathrm{LOD}$ & 4.5 & 10.1 \\
\hline SB_1_15 & R5 & 11.6 & 42.9 & 53.9 & 2.3 & $<\mathrm{LOD}$ & 2.9 & 13.7 \\
\hline SB_1_15 & R6 & 18 & 55 & 54.3 & 2.3 & $<\mathrm{LOD}$ & 4.7 & 10.7 \\
\hline SB_1_19 & $\mathrm{R} 1$ & 20 & 80 & 69.7 & 3.7 & 2.4 & 4.4 & 9.9 \\
\hline SB_1_19 & $\mathrm{R} 2$ & 14.9 & 35.8 & 64.1 & 4.1 & $<\mathrm{LOD}$ & 3.8 & 9.8 \\
\hline SB_1_19 & R3 & 15.3 & 46 & 49.5 & 2.4 & $<\mathrm{LOD}$ & 5 & 11.4 \\
\hline SB_1_19 & $\mathrm{R} 4$ & 15.4 & 45.1 & 53.1 & 3.7 & $<\mathrm{LOD}$ & 4 & 8 \\
\hline SB_1_19 & R5 & 20 & 50 & 63.2 & 4.9 & $<\mathrm{LOD}$ & 6.1 & 8.1 \\
\hline SB_1_19 & R6 & 16 & 47 & 119 & 2.8 & $<\mathrm{LOD}$ & 3 & 11.1 \\
\hline CH_1_5 & $\mathrm{R} 1$ & 30 & 74 & 75.6 & 3.2 & $<\mathrm{LOD}$ & 3.2 & 8.6 \\
\hline CH_1_5 & $\mathrm{R} 2$ & 51 & 71 & 72.4 & 6.5 & $<\mathrm{LOD}$ & 4 & 15 \\
\hline CH_1_5 & R3 & 47 & 75 & 72.5 & 3.6 & $<\mathrm{LOD}$ & 4.2 & 7.7 \\
\hline CH_1_5 & $\mathrm{R} 4$ & 52 & 160 & 151 & 5.2 & $<\mathrm{LOD}$ & 7.1 & 10.1 \\
\hline CH_1_5 & R5 & 31 & 62 & 73.5 & 5.4 & $<\mathrm{LOD}$ & 3.8 & 8.4 \\
\hline CH_1_5 & R6 & 39 & 136 & 118 & 4.8 & $<\mathrm{LOD}$ & 4.8 & 9.2 \\
\hline CH_1_6-1U & $\mathrm{R} 1$ & 82 & 55 & 59.7 & 5.4 & $<\mathrm{LOD}$ & 3.5 & 11.1 \\
\hline CH_1_6-1U & $\mathrm{R} 2$ & 60 & 55 & 60.5 & 6.1 & $<\mathrm{LOD}$ & 3.8 & 10.2 \\
\hline CH_1_6-1U & $\mathrm{R} 3$ & 55 & 45 & 53.9 & 6.3 & $<\mathrm{LOD}$ & 3.2 & 9.2 \\
\hline CH_1_6-1U & $\mathrm{R} 4$ & 60 & 52 & 62.9 & 6.4 & $<\mathrm{LOD}$ & $<\mathrm{LOD}$ & 9.5 \\
\hline CH_1_6-1U & R5 & 53 & 39 & 58.5 & 7.9 & $<\mathrm{LOD}$ & 4.4 & 5.7 \\
\hline CH_1_6-1U & R6 & 58 & 56 & 59.2 & 5.8 & $<\mathrm{LOD}$ & $<\mathrm{LOD}$ & 10.3 \\
\hline
\end{tabular}




\begin{tabular}{|c|c|c|c|c|c|c|c|c|}
\hline CH_1_6.5 & $\mathrm{R} 1$ & 72 & 58 & 67.1 & 8.9 & $<\mathrm{LOD}$ & 3.7 & 8 \\
\hline CH_1_6.5 & $\mathrm{R} 2$ & 54 & 43 & 56.1 & 5.5 & $<\mathrm{LOD}$ & 3.2 & 10 \\
\hline CH_1_6.5 & $\mathrm{R} 3$ & 61 & 59 & 64 & 6.6 & $<\mathrm{LOD}$ & 6.2 & 10.6 \\
\hline CH_1_6.5 & $\mathrm{R} 4$ & 64 & 48 & 58.2 & 7.4 & $<\mathrm{LOD}$ & 4.6 & 8 \\
\hline CH_1_6.5 & $\mathrm{R} 5$ & 54 & 59 & 66.5 & 6.9 & $<\mathrm{LOD}$ & 4.1 & 10 \\
\hline CH_1_6.5 & R6 & 60 & 46 & 55.5 & 7.1 & $<\mathrm{LOD}$ & $<\mathrm{LOD}$ & 6.4 \\
\hline CH_1_7 & $\mathrm{R} 1$ & 104 & 88 & 66.8 & 9.4 & $<\mathrm{LOD}$ & $<\mathrm{LOD}$ & 8 \\
\hline CH_1_7 & $\mathrm{R} 2$ & 86 & 68 & 61.2 & 8.4 & $<\mathrm{LOD}$ & $<\mathrm{LOD}$ & 9 \\
\hline CH_1_7 & $\mathrm{R} 3$ & 67 & 61 & 57.6 & 8.2 & $<\mathrm{LOD}$ & 4.6 & 7.4 \\
\hline CH_1_7 & $\mathrm{R} 4$ & 58 & 66 & 58.9 & 8.5 & $<\mathrm{LOD}$ & 3.2 & 8.7 \\
\hline CH_1_7 & $\mathrm{R} 5$ & 59 & 60 & 56.3 & 7.7 & $<\mathrm{LOD}$ & 3 & 8.1 \\
\hline CH_1_7 & R6 & 55 & 68 & 62 & 8.1 & $<\mathrm{LOD}$ & 3.1 & 9.3 \\
\hline CH_1_8 & $\mathrm{R} 1$ & 66 & 162 & 123 & 5.5 & $<\mathrm{LOD}$ & 4.5 & 10.2 \\
\hline CH_1_8 & $\mathrm{R} 2$ & 60 & 123 & 108 & 3.7 & $<\mathrm{LOD}$ & 5.2 & 11.6 \\
\hline CH_1_8 & $\mathrm{R} 3$ & 39 & 89 & 92.2 & 4.1 & $<\mathrm{LOD}$ & $<\mathrm{LOD}$ & 7 \\
\hline CH_1_8 & $\mathrm{R} 4$ & 68 & 113 & 106 & 4.1 & $<\mathrm{LOD}$ & 5.5 & 12.3 \\
\hline CH_1_8 & $\mathrm{R} 5$ & 83 & 79 & 77.8 & 4.2 & $<\mathrm{LOD}$ & 4 & 7.4 \\
\hline CH_1_8 & R6 & 45 & 98 & 84.3 & 3.3 & $<\mathrm{LOD}$ & 5.4 & 9.6 \\
\hline CH_1_9.8 & $\mathrm{R} 1$ & 47 & 121 & 113 & 4.4 & $<\mathrm{LOD}$ & 4.1 & 9 \\
\hline CH_1_9.8 & $\mathrm{R} 2$ & 53 & 172 & 135 & 3.1 & $<\mathrm{LOD}$ & 4.3 & 14.4 \\
\hline CH_1_9.8 & $\mathrm{R} 3$ & 31 & 118 & 107 & 4.7 & $<\mathrm{LOD}$ & 4.1 & 8.4 \\
\hline CH_1_9.8 & $\mathrm{R} 4$ & 67 & 152 & 118 & 5.3 & $<\mathrm{LOD}$ & 4.4 & 9.5 \\
\hline CH_1_9.8 & $\mathrm{R} 5$ & 46 & 147 & 129 & 4.3 & $<\mathrm{LOD}$ & 3.7 & 11.3 \\
\hline CH_1_9.8 & R6 & 33 & 103 & 94.2 & 4.8 & $<\mathrm{LOD}$ & 3.3 & 8.8 \\
\hline CH_1_11 & $\mathrm{R} 1$ & 61 & 223 & 129 & 4.9 & $<\mathrm{LOD}$ & 6.4 & 9.6 \\
\hline CH_1_11 & $\mathrm{R} 2$ & 40 & 118 & 91.4 & 3.4 & $<\mathrm{LOD}$ & 3.6 & 9.9 \\
\hline CH_1_11 & $\mathrm{R} 3$ & 25 & 98 & 69.9 & 4.6 & $<\mathrm{LOD}$ & 3.9 & 7.2 \\
\hline CH_1_11 & $\mathrm{R} 4$ & 28 & 74 & 58.2 & 2.5 & $<\mathrm{LOD}$ & $<\mathrm{LOD}$ & 6.8 \\
\hline CH_1_11 & $\mathrm{R} 5$ & 31 & 121 & 78 & 5.8 & $<\mathrm{LOD}$ & 3.3 & 6.1 \\
\hline CH_1_11 & R6 & 49 & 167 & 113 & 4.8 & $<\mathrm{LOD}$ & 4.8 & 7.3 \\
\hline CH_1_13.1 & $\mathrm{R} 1$ & 53 & 93 & 109 & 7.6 & $<\mathrm{LOD}$ & 4.7 & 43.7 \\
\hline CH_1_13.1 & $\mathrm{R} 2$ & 38 & 60 & 85.2 & 7.5 & $<\mathrm{LOD}$ & 6 & 33.5 \\
\hline CH_1_13.1 & $\mathrm{R} 3$ & 52 & 91 & 100 & 8 & $<\mathrm{LOD}$ & 8.8 & 41.5 \\
\hline CH_1_13.1 & $\mathrm{R} 4$ & 39 & 61 & 94.1 & 11.4 & $<\mathrm{LOD}$ & 4.7 & 39.7 \\
\hline CH_1_13.1 & $\mathrm{R} 5$ & 44 & 83 & 101 & 6.9 & $<\mathrm{LOD}$ & 5.7 & 39.1 \\
\hline CH_1_13.1 & R6 & 42 & 68 & 85.4 & 6.1 & $<\mathrm{LOD}$ & 4.4 & 38.7 \\
\hline
\end{tabular}




\begin{tabular}{|lllllclcc|}
\hline LPL-TT (a) & R1 & 38 & 21 & 62 & 19.1 & $<$ LOD & 7.2 & 21.6 \\
LPL-TT (a) & R2 & 28 & 29 & 63 & 18.3 & $<$ LOD & 6.9 & 25.1 \\
LPL-TT (a) & R3 & 42 & 24 & 65 & 20.1 & $<$ LOD & 6.4 & 21.7 \\
LPL-TT (a) & R4 & 31 & 27 & 67 & 18 & <LOD & $<$ LOD & 23.8 \\
\hline LPL-PT (b) & R1 & 25 & 12 & 48 & 26.9 & $<$ LOD & $<$ LOD & 17.6 \\
LPL-PT (b) & R2 & 20 & 12 & 46 & 30.8 & $<$ LOD & $<$ LOD & 16.6 \\
LPL-PT (b) & R3 & 29 & 18 & 51 & 33.6 & $<$ LOD & $<$ LOD & 16.7 \\
LPL-PT (b) & R4 & 25 & 14 & 44 & 27 & $<$ LOD & $<$ LOD & 21.4 \\
\hline LPL-OR (c) & R1 & 25 & 21 & 44 & $<$ LOD & $<$ LOD & 6.3 & 10.8 \\
LPL-OR (c) & R2 & 18 & 12 & 32.7 & 4.4 & $<$ LOD & $<$ LOD & 11.1 \\
LPL-OR (c) & R3 & 18 & 14 & 36.4 & $<$ LOD & $<$ LOD & 7.6 & 10.1 \\
LPL-OR (c) & R4 & 23 & 12 & 34.2 & $<$ LOD & 2.5 & 6.8 & 9.3 \\
\hline
\end{tabular}


APPENDIX E: Correlation Analysis

\begin{tabular}{|c|c|c|c|c|c|c|c|c|c|}
\hline$C G S$ & sand-silt-clay & silt-clay & $A v g O C$ & $\mathrm{Cr}$ & $\mathrm{Cu}$ & $Z n$ & As & $\mathrm{Hg}$ & $P b$ \\
\hline$\%$ Fine & 1 & & & & & & & & \\
\hline silt-clay & 0.57 & 1 & & & & & & & \\
\hline Avg OC & 0.33 & 0.49 & 1 & & & & & & \\
\hline $\mathrm{Cr}$ & 0.42 & 0.74 & 0.59 & 1 & & & & & \\
\hline $\mathrm{Cu}$ & 0.09 & 0.34 & 0.64 & 0.23 & 1 & & & & \\
\hline $\mathrm{Zn}$ & 0.30 & 0.45 & 0.96 & 0.65 & 0.57 & 1 & & & \\
\hline As & 0.16 & 0.19 & 0.65 & 0.22 & 0.69 & 0.58 & 1 & & \\
\hline $\mathrm{Hg}$ & 0.28 & 0.66 & 0.70 & 0.68 & 0.42 & 0.72 & 0.63 & 1 & \\
\hline $\mathrm{Pb}$ & 0.37 & 0.63 & 0.69 & 0.75 & 0.43 & 0.68 & 0.62 & 0.89 & 1 \\
\hline$B G S$ & sand-silt-clay & silt-clay & $A v g O C$ & $\mathrm{Cr}$ & $C u$ & $Z n$ & As & $H g$ & $\mathrm{~Pb}$ \\
\hline$\%$ Fine & 1 & & & & & & & & \\
\hline silt-clay & 0.42 & 1 & & & & & & & \\
\hline Avg OC & -0.18 & 0.31 & 1 & & & & & & \\
\hline $\mathrm{Cr}$ & -0.48 & 0.11 & 0.08 & 1 & & & & & \\
\hline $\mathrm{Cu}$ & -0.67 & -0.18 & 0.11 & 0.43 & 1 & & & & \\
\hline $\mathrm{Zn}$ & -0.26 & 0.29 & 0.88 & 0.17 & 0.36 & 1 & & & \\
\hline As & -0.26 & 0.38 & 0.59 & 0.32 & 0.18 & 0.52 & 1 & & \\
\hline $\mathrm{Hg}$ & -0.46 & 0.06 & 0.24 & 0.46 & 0.43 & 0.36 & 0.44 & 1 & \\
\hline $\mathrm{Pb}$ & -0.19 & 0.32 & 0.59 & 0.18 & 0.14 & 0.60 & 0.65 & 0.66 & 1 \\
\hline \multicolumn{2}{|l|}{$B G S: C G S$} & & & & & & & & \\
\hline $\mathrm{Cr}$ & -0.01 & & & & & & & & \\
\hline $\mathrm{Cu}$ & -0.22 & & & & & & & & \\
\hline $\mathrm{Zn}$ & -0.18 & & & & & & & & \\
\hline As & -0.21 & & & & & & & & \\
\hline $\mathrm{Hg}$ & -0.34 & & & & & & & & \\
\hline $\mathrm{Pb}$ & -0.34 & & & & & & & & \\
\hline$\% \mathrm{OC}$ & -0.22 & & & & & & & & \\
\hline
\end{tabular}




\begin{tabular}{cc|}
\hline \multicolumn{2}{|c|}{ Regression Statistics } \\
\hline Multiple R & 0.711437 \\
R Square & 0.506142 \\
Adjusted R Square & 0.487148 \\
Standard Error & 1126.897 \\
Observations & 55 \\
\hline
\end{tabular}

ANOVA

\begin{tabular}{c|c|c|c|c|c|}
\hline & $d f$ & $S S$ & $M S$ & $F$ & Significance $F$ \\
\hline Regression & 2 & 67677252 & 33838626 & 26.64675 & $1.08 \mathrm{E}-08$ \\
Residual & 52 & 66034638 & 1269897 & & \\
Total & 54 & 133711890 & & & \\
\hline
\end{tabular}

\begin{tabular}{ccccccccccc|c|}
\hline & Coefficients & Standard Error & t Stat & P-value & Lower 95\% & Upper 95\% & Lower 95.0\% & Upper 95.0\% \\
\hline Intercept & -1046.838 & 417.4498 & -2.5077 & 0.0153 & -1884.5121 & -209.1636 & -1884.5121 & -209.1636 \\
X Variable 1 & 1132.246 & 439.4945 & 2.5762 & 0.0129 & 250.3355 & 2014.1559 & 250.3355 & 2014.1559 \\
X Variable 2 & 906.1939 & 330.259 & 2.7439 & 0.0083 & 243.4807 & 1568.9071 & 243.4807 & 1568.9071 \\
\hline
\end{tabular}

